\title{
Simulated Effects of Proposed Ground-Water Pumping in 17 Basins of East-Central and Southern Nevada
}

By DONALD H. SCHAEFER and JAMES R. HARRILL

\section{U.S. GEOLOGICAL SURVEY}

Water-Resources Investigations Report 95-4173

Prepared in cooperation with the NATIONAL PARK SERVICE, U.S. FISH AND WILDLIFE SERVICE, BUREAU OF LAND MANAGEMENT, and BUREAU OF INDIAN AFFAIRS

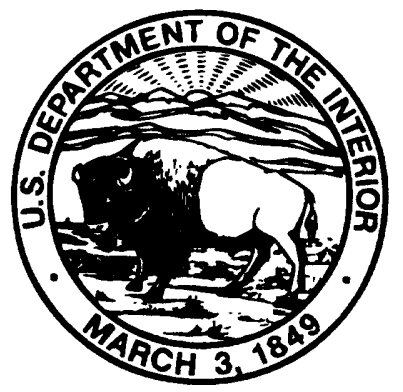

Carson City, Nevada 1995 


\title{
U.S. DEPARTMENT OF THE INTERIOR BRUCE BABBITT, Secretary
}

\author{
U.S. GEOLOGICAL SURVEY \\ GORDON P. EATON, Director
}

Any use of trade names in this publication is for descriptive purposes

only and does not constitute endorsement by the U.S. Government

For additional information write to:

\section{U.S. Geological Survey} 333 West Nye Lane, Room 203

Carson City, NV 89706-0866
Copies of this report can be purchased from:

U.S. Geological Survey

Information Services

Box 25286, MS 517

Denver Federal Center

Denver, CO 80225-0046 


\section{CONTENTS}

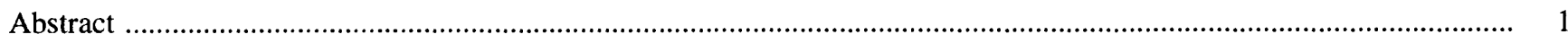

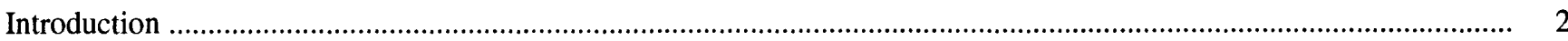

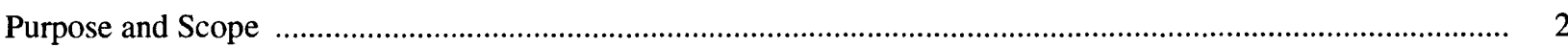

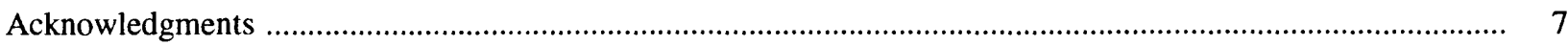

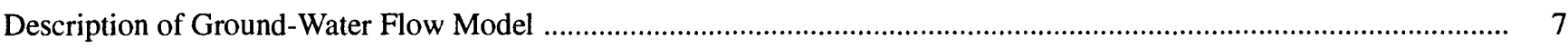

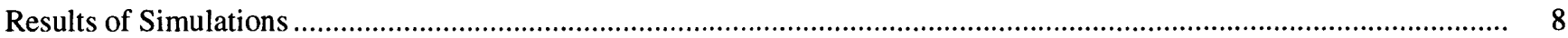

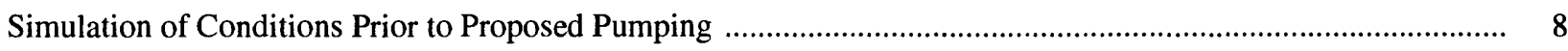

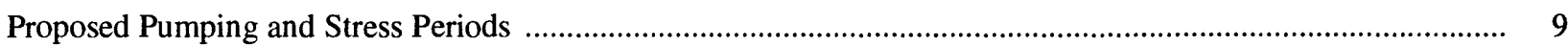

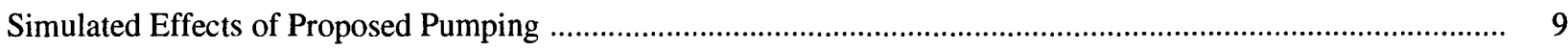

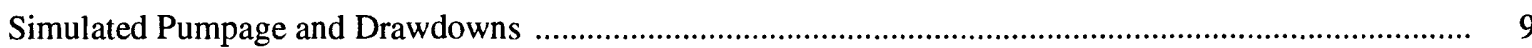

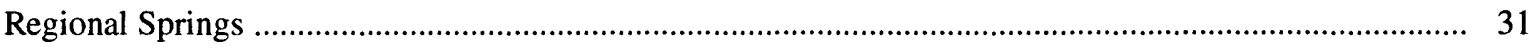

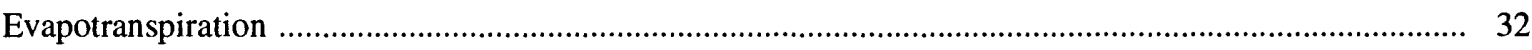

Sensitivity of Model Results to Storage Values ......................................................................................

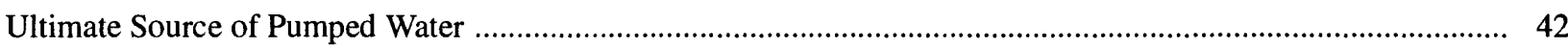

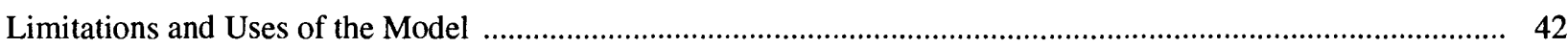

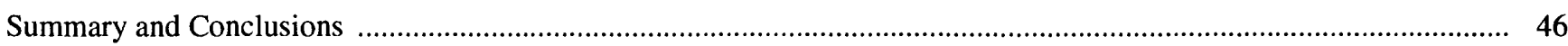

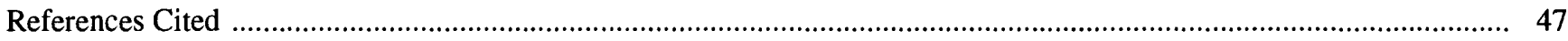

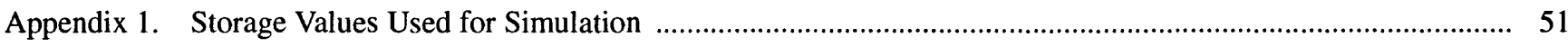

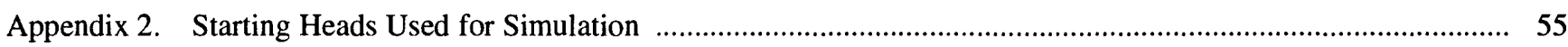

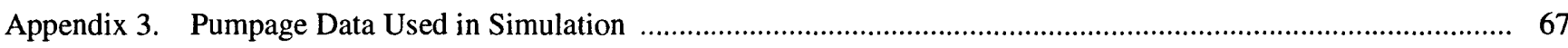

\section{FIGURES}

1. Map showing location of study area and selected geographic features, Great Basin area, Nevada-Utah.

2. Map showing starting ground-water levels simulated for upper and lower model layers and general direction of ground-water flow

3. Map showing location of 17 basins (hydrographic areas) in which pumping is proposed and outline of model grid used in simulations

4-10. Maps showing simulated water-level drawdowns for upper and lower model layers:

4. Stress-period one, time-step two, after 7 years into simulation

5. Stress-period two, time-step two, after 11 years into simulation .................................................. 16

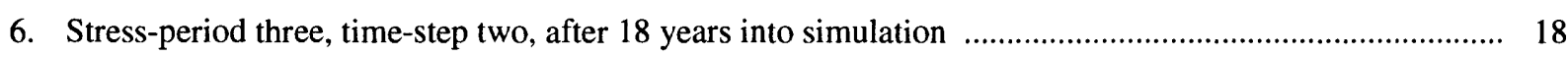

7. Stress-period four, time-step three, after 30 years into simulation ................................................. 20

8. Stress-period five, time-step five, after 100.7 years into simulation ................................................ 22

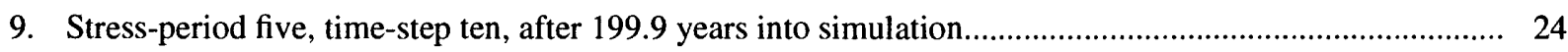

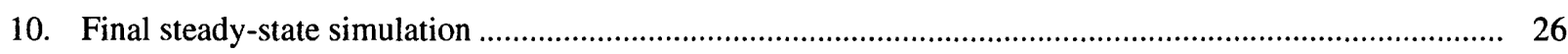

11. Map showing location of spring cells, pumping cells, and selected cells in model grid .................................. 28

12-13. Hydrographs for selected cells representing areas in:

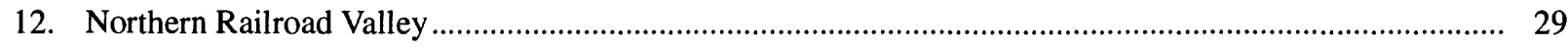

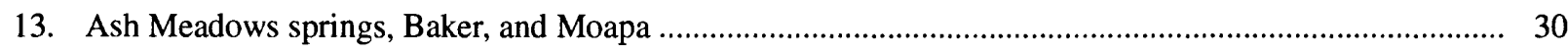


14-18. Graphs showing changes in:

14. Discharge of selected regional springs with changing pumpage.

15. Simulated evapotranspiration at cells in selected basins with changes in proposed pumpage

16. Total model-simulated spring discharge with selected storage values and changing pumpage.

17. Total model-simulated evapotranspiration with selected storage values and changing pumpage

18. Total model-simulated water removed from storage with selected storage values and changing pumpage

19-23. Hydrographs of simulated water-level drawdowns associated with selected storage values for selected cells representing areas in:

19. Ash Meadows

20. Baker

21. Duckwater

22. Northern Railroad Valley

23. Moapa

24. Graphs showing changes in model-budget components and sources of pumpage

\section{TABLES}

1. Pumpage proposed by Las Vegas Valley Water District during first 20 years of pumping, by basin, east-central and southern Nevada

2. Simulated stress periods and pumpage

3. Estimated flow, simulated steady-state flow, and flow at selected times during simulated pumping, for selected springs.

4. Simulated pumpage and evapotranspiration rates in selected areas.

\section{CONVERSION FACTORS AND VERTICAL DATUM}

\begin{tabular}{rll}
\hline Multiply & By & To obtain \\
\hline acre-foot (acre-ft) & 0.001233 & cubic hectometer \\
acre-foot per year (acre-ft/yr) & 0.001233 & cubic hectometer per year \\
cubic foot per second $(\mathrm{ft} / \mathrm{s})$ & 0.02832 & cubic meter per second \\
$\mathrm{foot}(\mathrm{ft})$ & 0.3048 & meter \\
$\mathrm{mile}(\mathrm{mi})$ & 1.609 & kilometer \\
pound per square inch $\left(\mathrm{lb} / \mathrm{in}^{2}\right)$ & 0.07031 & kilogram per square centimeter \\
square mile $\left(\mathrm{mi}^{2}\right)$ & 2.590 & square kilometer \\
\hline
\end{tabular}

Equivalents: 1 acre-foot per year (acre-ft/yr) $=0.0014$ cubic foot per second $\left(\mathrm{ft}^{3} / \mathrm{s}\right) ; 1 \mathrm{ft}^{3} / \mathrm{s}=724$ acre- $\mathrm{ft} / \mathrm{yr}$.

Sea level: In this report, "sea level" refers to the National Geodetic Vertical Datum of 1929 (NGVD of 1929, formerly called "Sea-Level Datum of 1929"), which is derived from a general adjustment of the first-order leveling networks of the United States and Canada. 


\title{
Simulated Effects of Proposed Ground-Water Pumping in 17 Basins of East-Central and Southern Nevada
}

\author{
By Donald H. Schaefer and James R. Harrill
}

\section{ABSTRACT}

The Las Vegas Valley Water District filed 146 applications in 1989 to pump about 800,000 acre-feet per year (acre-ft/yr) of ground water from 26 basins in east-central and southern Nevada, for use in the Las Vegas urban area. The quantity of water that they proposed to pump was eventually reduced to a maximum of 180,800 acre-ft/yr in 17 basins. A previously constructed, two-layer computer model of the carbonate-rock province was configured to simulate transient conditions and used to develop first approximations of the possible effects of these withdrawals. Simulations were made using the phased pumping schedule proposed by the water district that reaches a maximum pumpage rate of 180,800 acre-ft/yr after 18 years. No other pumping was simulated, so the results represent only effects of pumping proposed by the water district. Existing pumping was not simulated in the original model, so the effects simulated in this report are superimposed on conditions that are representative of the carbonaterock province prior to any development.

The simulations indicate that the proposed pumping would cause water-level declines in many ground-water basins, decreased flow at several regional springs, and decreased discharge by evapotranspiration from the basins.

Ground-water levels ultimately could decline several hundred feet in the basins scheduled to supply most of the pumped ground water.
Model declines in the carbonate aquifer are somewhat larger than simulated declines in the overlying basin-fill deposits.

Simulated regional springflow decreased in several cells, including those representing the Muddy River springs, Hiko-Crystal-Ash Springs area, and the Ash Meadows springs area. Model simulations show flow decreases of about 11 percent, 14 percent, and 2 percent, respectively, at these springs after about 100 years of pumping.

Simulated evapotranspiration also deceased in many basins; the largest decreases are in basins where ground-water withdrawals are greatest. These basins include Railroad, Spring, and Snake Valleys. The largest decrease in simulated evapotranspiration occurred in southern Railroad Valley-about 33 cubic feet per second (64 percent) after about 100 years of pumping.

Model-sensitivity tests indicate that longterm results are relatively insensitive to variations in values used for aquifer storage. Model simulations were made using a 50-percent variation in upper-layer storage coefficients and a range of values for the lower layer. The analysis showed little deviation in model results of water-level changes, springflow, or evapotranspiration rates.

The simulation results are based on a computer model of regional ground-water flow that greatly simplifies the complex distribution of geology and, consequently, the hydraulic properties of many of the rocks in the Great Basin. The adequacy of the model to simulate the effects of 
this proposed pumping cannot be tested until pumping stresses have been in place long enough to cause measurable effects within the system.

\section{INTRODUCTION}

The carbonate-rock province of the Great Basin is characterized by a series of generally northto northeast-trending mountain ranges composed predominantly of carbonate rocks (limestone and dolomite) of Paleozoic age. The intervening valleys are filled with detritus (gravels, sands, silts, and clays) eroded from the adjacent mountain ranges. These basin-fill deposits may be several thousand feet thick (Plume and Carlton, 1988).

Virtually all types of rocks and deposits within the province contain ground water. The basin-fill deposits are the primary aquifer system, and most of the present ground-water pumpage is from these deposits. Carbonate rocks that form some of the mountain ranges and underlie the basin-fill deposits in many areas may also be significant ground-water reservoirs in some places. Where they are fractured or contain solution openings, the carbonate rocks commonly can act as conduits for regional ground-water flow. Most of the larger regional springs in the province issue from carbonate rocks or from basin-fill deposits overlying or adjacent to carbonate rocks. These springs discharge ground water that has moved through the regional flow systems in the carbonate-rock aquifers from distant source areas.

As part of the Great Basin Regional AquiferSystem Analysis (RASA) project, the 100,000- $\mathrm{mi}^{2}$ carbonate-rock province (fig. 1), also termed "the province" herein, was modeled using a digital, groundwater flow model to refine concepts of regional ground-water flow in the Great Basin (Harrill and others, 1983 and 1988; Prudic and others, 1993). The modeling is described in detail by Prudic and others (1993). In general, the simulated flow in the eastern and northern parts of the province is northward toward the Great Salt Lake and the Humboldt River; elsewhere in the province, flows are generally southward, toward either Death Valley or the Virgin and Colorado Rivers (fig. 2). A summary description of the various local and regional ground-water flow systems was reported by Harrill and others (1988).
In 1989, the Las Vegas Valley Water District (LVVWD) filed 146 applications with the Nevada State Engineer for water rights in east-central and southern Nevada. These original applications were for 26 basins throughout the carbonate-rock province and totaled about 800,000 acre-ft/yr of ground-water withdrawals. The total amount of pumpage was eventually reduced to a maximum 180,800 acre-ft/yr from 17 basins, or hydrographic areas ${ }^{1}$ (figs. 1 and 3; LVVWD, written commun., 1992).

In 1991, several Department of the Interior (DOI) bureaus requested that the U.S. Geological Survey rerun the regional-scale ground-water flow model to obtain first approximations of probable effects of increased ground-water pumping in the carbonate-rock province. The simulation was made using a phased pumping schedule, with ultimate pumpage totaling $180,800 \mathrm{acre}-\mathrm{ft} / \mathrm{yr}$. The agencies were particularly interested in the possible effects on regional flow, large regional springs, and evapotranspiration that could affect their water interests in the province.

The model used to simulate these effects has large grid spacing and is based on a regional-scale conceptualization of ground-water flow. The model is considered adequate to develop first approximations of probable regional-scale effects, but is not adequate to support detailed predictions. A more detailed representation of the system and more information about how the system will respond to pumping stresses would permit the assessment of estimated effects, but this would require more detailed delineation of the aquifers both laterally and vertically, as well as additional information on hydrologic properties of the aquifers.

\section{Purpose and Scope}

The purpose of this report is to document the results obtained using the regional ground-water flow model to estimate potential effects of implementing the proposed water-rights applications filed by LVVWD.

\footnotetext{
${ }^{1}$ Formal hydrographic areas in Nevada were delineated systematically by the U.S. Geological Survey and Nevada Division of Water Resources in the late 1960's for scientific and administrative purposes (Rush, 1968). The official hydrographic area names, numbers, and geographic boundaries continue to be used in Geological Survey scientific reports and Division of Water Resources administrative activities.
} 


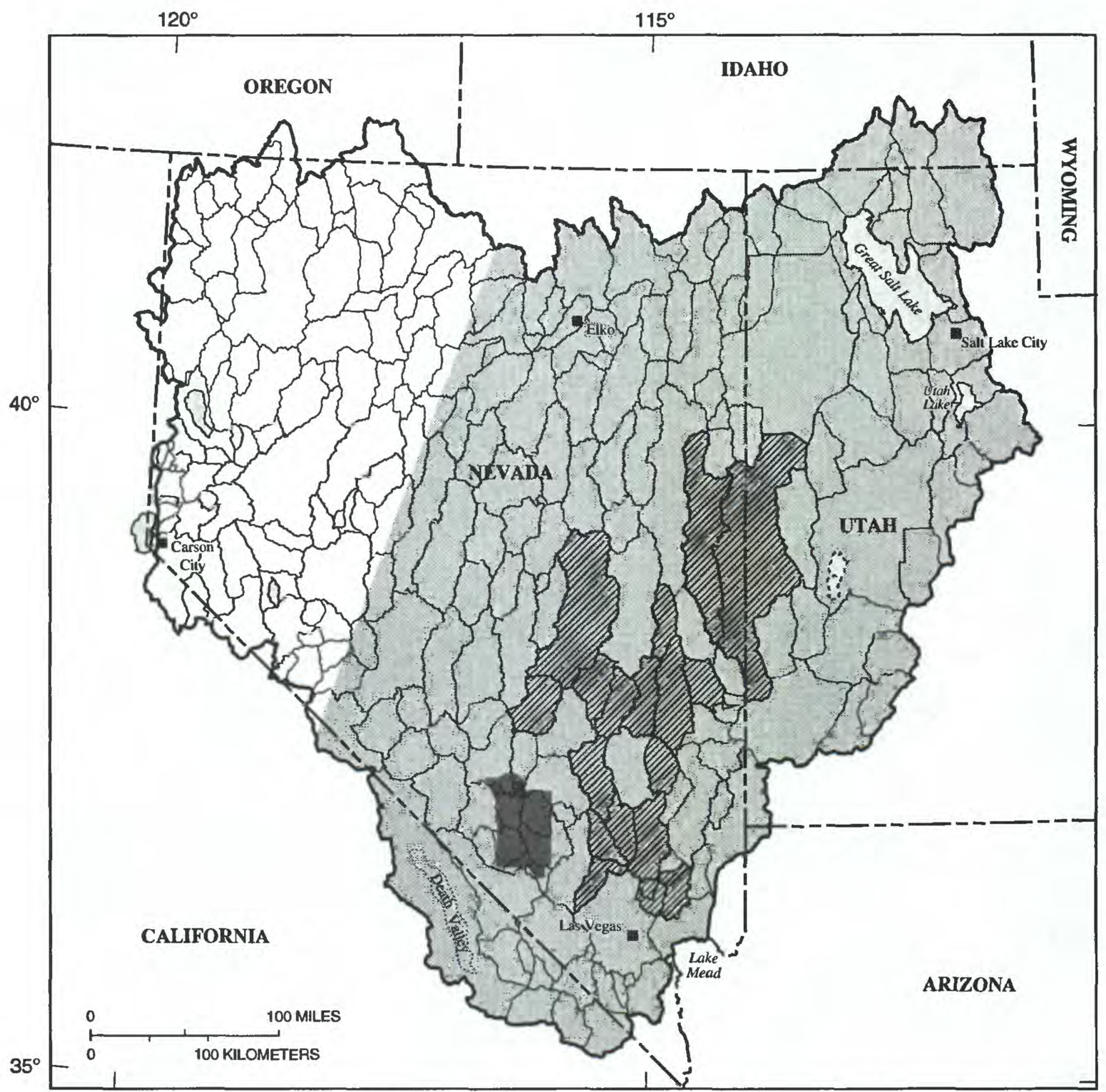

Base modified from U.S. Geological Survey digital data, 1:100,000 and 1:250,000 Albers Equal-Area Conic projection

Standard parallels $29^{\circ} 30^{\circ}$ and $45^{\circ} 30^{\prime}$, central meridian $-114^{\circ}$

From Prudic and others (1993, fig. 2) and Rush (1968)

EXPLANATION

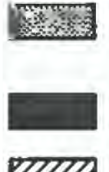

EIIIS
Carbonate-rock province study area Boundary is approximate

Nevada Test Site

Hydrographic area whare pumplng is proposed by Las Vegaa Valley Water Dlstrict

\section{Boundary of Great Basin Reglonal Aquifer-System} Analysis (RASA) atudy area

Boundary of hydrographic area or subarea

Figure 1. Location of study area and selected geographic features, Great Basin area, Nevada-Utah. 


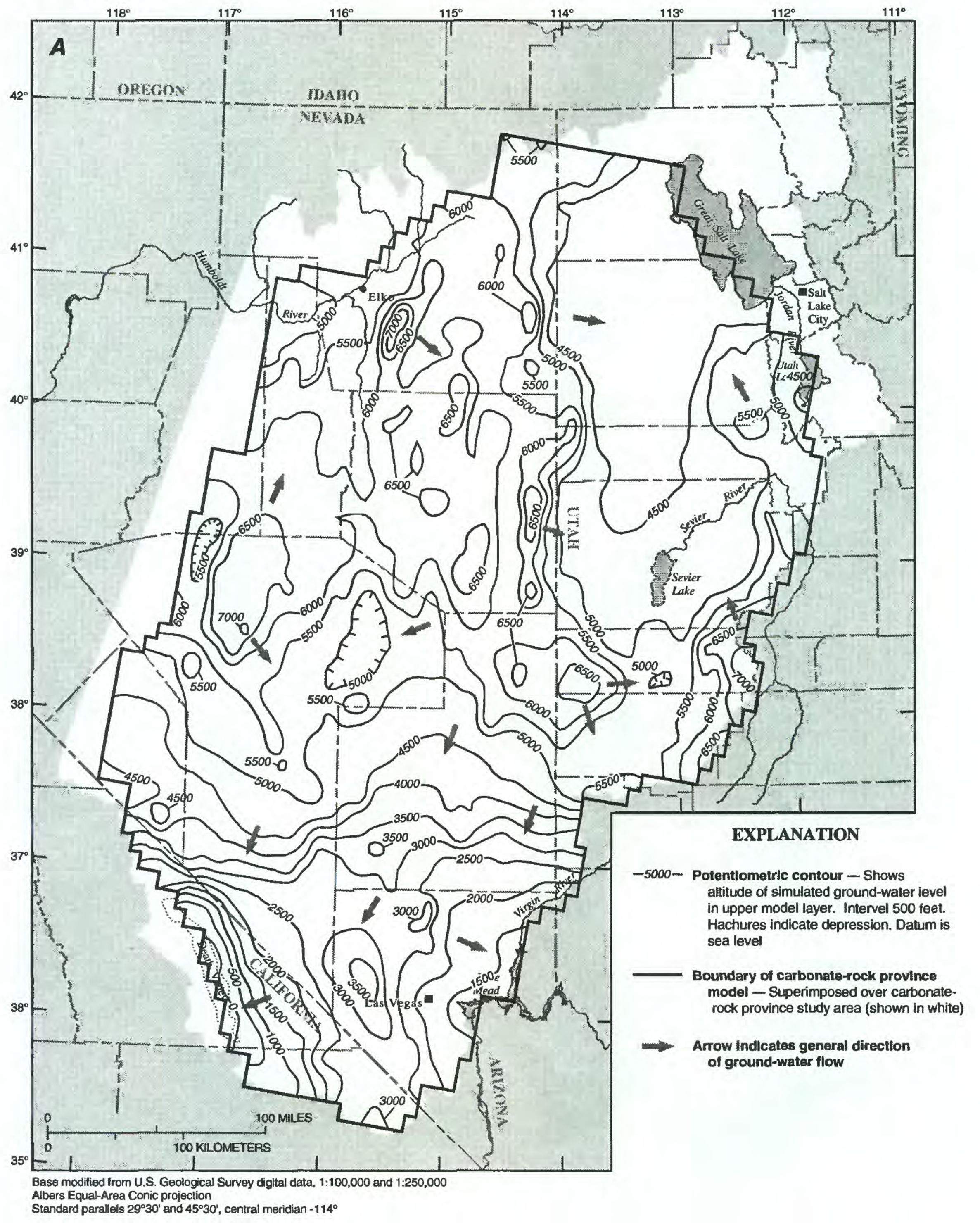

Figure 2. Starting ground-water levels simulated for $(A)$ upper model layer and $(B)$ lower model layer (from Prudic and others, 1993, fig. 19), and general direction of ground-water flow. 

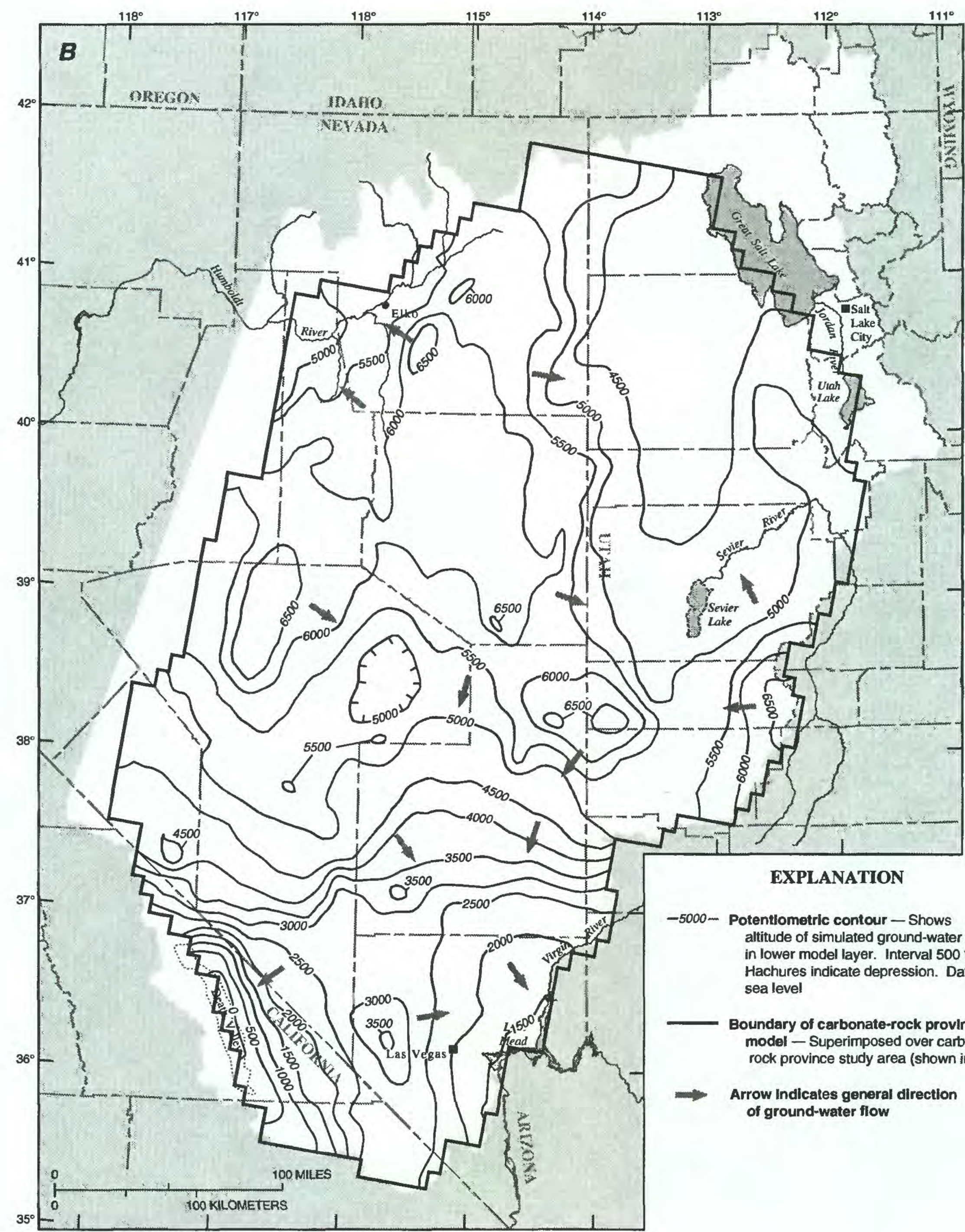

EXPLANATION

altitude of simulated ground-water level in lower model layer. Interval 500 feet. Hachures indicate depression. Datum is sea level

Boundary of carbonate-rock province model - Superimposed over carbonaterock province study area (shown in white)

Arrow Indicates general direction of ground-water flow

Base modified from U.S. Geological Survey digital data, 1:100,000 and 1:250,000 Albers Equal-Area Conic projection

Standard parallels $29^{\circ} 30^{\prime}$ and $45^{\circ} 30^{\prime}$, central meridian $-114^{\circ}$

Figure 2. Continued. 


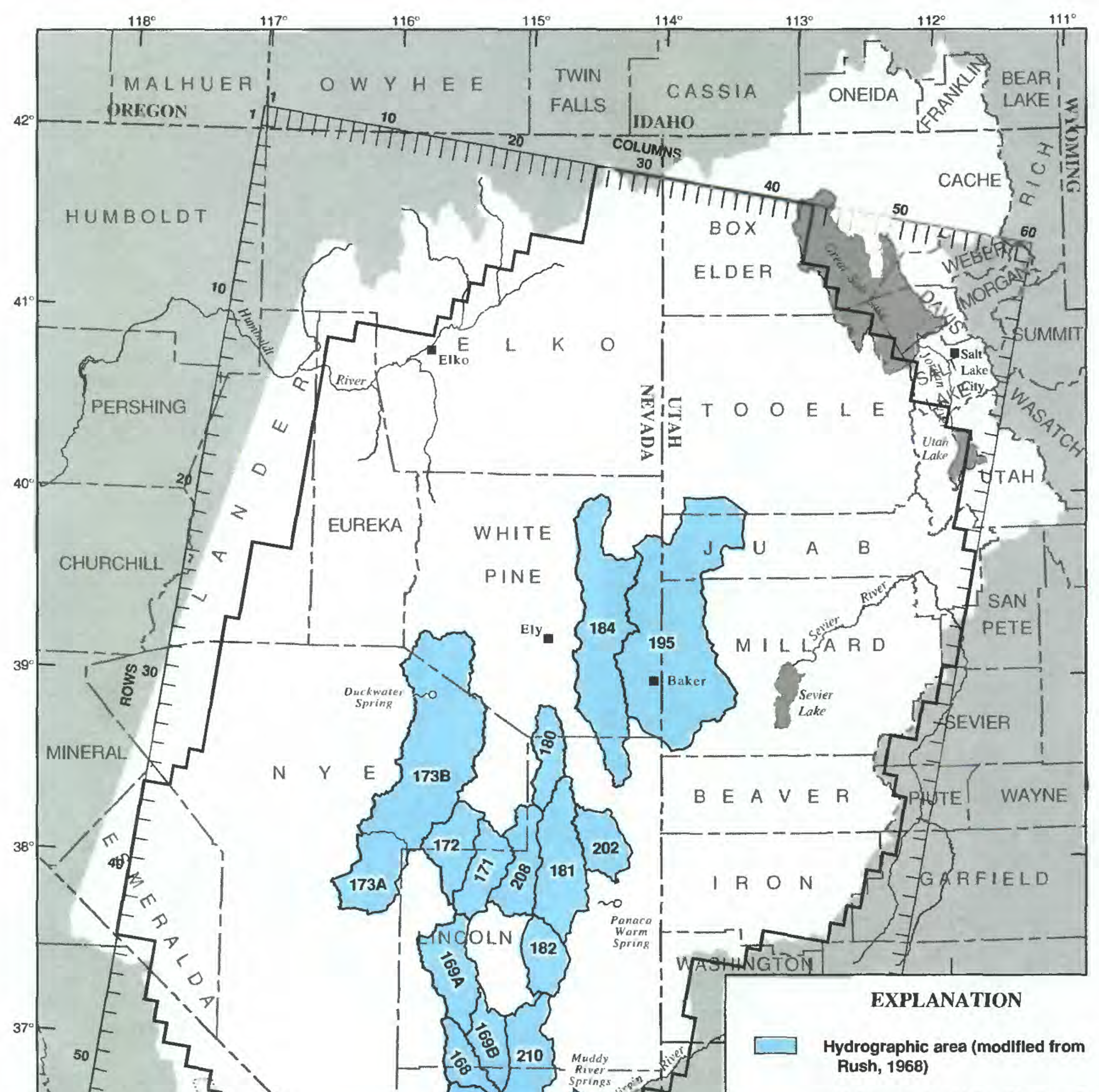

168. Three Lakes Valley (Northern Part) 169A, B. Tikapoo Valley (Northern and Southern Parts)

171. Coal Valley

172. Garden Valley

173A, B. Railroad Valley (Southem and Northern Parts)

180. Cave Valley

181. Dry Lake Valley

182. Delamar Valley

184. Spring Valley

195. Snake Valley

202. Patterson Valley

208. Pahroc Valley

210. Coyote Spring Valley

211. Three Lakes Valley (Southem Part)

216. Garnet (Dry Lake) Valley

217. Hidden Valley

218. California Wash

Albers Equal-Area Conic projection

Boundary of carbonate-rock provinca model

Figure 3. Location of 17 basins (hydrographic areas) in which pumping is proposed and outline of model grid used in simulations. 
The report includes a description of the simulated effects of the pumping on regional springflow, evapotranspiration (ET) rates, and ground-water levels in 17 basins in the carbonate-rock province of the Great Basin. The model results are conceptual in nature because the model used is conceptual (Prudic and others, 1993, p. 18).

The conceptual model used several assumptions (Prudic and others, 1993, p. 15). These include:

(1) flow through fractures and solution openings is the same as flow through porous media and thereby conforms to Darcy's Law, (2) steady-state conditions were in effect prior to ground-water development in the area, and (3) transmissivity is heterogeneous throughout the study area but is homogeneous within each individual cell.

Data used in the model are highly generalized, and the assumptions are simplifications of the actual system. Furthermore, the locations of proposed wells and the proposed pumping schedule described in this report are likely to be revised. Consequently, results reported should be used only as indications of possible generalized effects.

\section{Acknowledgments}

This study was prepared in cooperation with the following Department of the Interior bureaus: National Park Service, U.S. Fish and Wildlife Service, Bureau of Land Management, and Bureau of Indian Affairs. The authors thank the members of the Hydrology Task Group for their valuable insight into the relevant issues of this study. This group was composed of: Paul K. Christensen, Alice E. Johns, and George M. "Mel" Essington, National Park Service (lead agency); Patricia J. Fielder and Paul J. Barrett, U.S. Fish and Wildlife Service; Paul C. Summers and James C. McLaughlin, Bureau of Land Management; and Bernard DeRook, Bureau of Indian Affairs. The frequent discussions and meetings with this group contributed considerably to the successful completion of this project.

\section{DESCRIPTION OF GROUND-WATER FLOW MODEL}

The ground-water flow model used for this study was constructed to conceptualize regional flow in the carbonate rock province of the Great Basin (Prudic and others, 1993). The model consists of two layers of 3,660 cells ( 60 columns by 61 rows; fig. 3 ); each cell is $5 \mathrm{mi}$ wide by $7-1 / 2 \mathrm{mi}$ long. Not all cells in the grid are used in the model simulation; each layer contains 2,456 active cells.

The program used to simulate regional groundwater flow is the modular three-dimensional finite difference ground-water flow model, MODFLOW, written by McDonald and Harbaugh (1988). The mathematics involved in using the model to simulate ground-water flow systems is described in detail in that reference. The specific use of MODFLOW to simulate the regional ground-water system in the Great Basin is described by Prudic and others (1993).

The data used in the model, such as transmissivity values, recharge values, and other data sets, are documented (Schaefer, 1993). Boundary conditions for the model are described in detail by Prudic and others, (1993, p. 18).

In general, the model boundaries of the province extend to mountain ranges that consist mostly of lowpermeability consolidated rock and are assumed to be no-flow boundaries. General head boundaries exist along the northeast, northwest, southeast, and southwest borders of the model (Prudic and others, 1993, fig. 9). A no-flow boundary is simulated beneath the lower layer of the model representing the depth below which there is little ground-water flow.

Recharge to the model is simulated as a constant flux to the upper model layer in cells that correspond to mountain ranges. Discharge occurs primarily as evapotranspiration and is simulated as a headdependent flow boundary in the upper model layer. Regional springs are simulated as drains from the lower layer of the model.

The SIP (Strongly Implicit Procedure) solver (McDonald and Harbaugh, 1988, p. 12-1) was used by the model to solve the ground-water flow equations. SIP is a method for solving large systems of simultaneous linear equations by iteration. A closure criterion of $0.1 \mathrm{ft}$ and an acceleration parameter (a value that increases or decreases head change at each iteration) of 0.8 was chosen.

Four major assumptions were used for the transient simulations of the flow model. The first was that the only pumpage simulated was that proposed by LVVWD, to produce a representation of the overall effects that development of these applications might have on the regional ground-water flow systems. 
In keeping with the conceptual nature of the model, the simulation provides information about the probable areas that may be affected, the general magnitude of possible water-level declines or other effects, and the general period of time over which changes may be expected to occur. Prediction of specific, detailed water-level changes throughout the area would require that effects of the proposed pumping be superimposed on the effects of existing and other anticipated future pumping. That was beyond the scope of this analysis.

The second assumption was that storage values used for transient simulations for the upper layer were based on the predominant aquifer material in each cell, determined from surficial maps. This distribution may not be totally correct because the material may be different at depth in the zone of saturation. Storage coefficients in the upper layer also assume dewatering of the sediments.

Rock and deposit types were divided into three categories-basin-fill materials, carbonate rocks, and other consolidated rocks. Distribution of these units is shown by Prudic and others (1993, fig. 15). Average values for storage coefficients in layer one were assigned to each of these materials. For basin-fill material, a value of 0.1 was assigned on the basis of average values of specific yield used in U.S. Geological Survey reconnaissance evaluations of ground-water resources in most basins of the study area. For carbonate rocks, a value of 0.05 was assigned on the basis of an average porosity value of 0.047 determined from geophysical logs of five wells in the Coyote Spring Valley area (Berger, 1992, p. 18). For other rocks, a value of 0.01 was assigned on the basis of a range of yalues for fractured rocks given by Snow (1979, table 1).

The storage coefficient for the lower layer was estimated on the basis of the probable average porosity of the rocks present ( 0.01 to 0.05$)$, the effective thickness of aquifer material (probably between 5,000 and $10,000 \mathrm{ft}$ ), the bulk modulus of elasticity of water $\left(3 \times 10^{5} \mathrm{lb} / \mathrm{in}^{2}\right)$, and the bulk modulus of elasticity of the solid skeleton of the aquifer (for limestone, about $4.8 \times 10^{6}$ to $5.4 \times 10^{6} \mathrm{lb} / \mathrm{in}^{2}$; Krynine and Judd, 1957, table 2.5). The following equation from Lohman $(1972$, p. 9) was used to estimate the coefficients:

$$
S=\theta \gamma b\left(\frac{1}{E_{w}}+\frac{C}{\theta E_{s}}\right) \text {, }
$$

where $S$ is storage coefficient (dimensionless);

$\theta$ is porosity, as a decimal fraction;

$\gamma$ is specific weight per unit, $62.4 \mathrm{lb} / \mathrm{ft}^{3} \div$ $144 \mathrm{in}^{2} / \mathrm{ft}^{2}=0.434\left(\mathrm{lb} / \mathrm{in}^{2}\right) / \mathrm{ft}$;

$b$ is thickness, in feet;

$E_{w}$ is bulk modulus of elasticity of water;

$C$ is a dimensionless ratio, which may be considered unity in an uncemented granular material; in a solid aquifer, such as limestone with tubular solution channels, $C$ is apparently equal to porosity; and

$E_{s}$ is bulk modulus of elasticity of the solid skeleton of an aquifer.

Estimates of storage values based on the above numbers ranged from $7.6 \times 10^{-5}$ to $1.2 \times 10^{-3}$. For purposes of this report, the storage coefficient for the lower layer was set at the midrange of these values, $6 \times 10^{-4}$, for the entire layer. The data set for storage values used in the model is listed in appendix 1.

The third major assumption used in the model is from the previous steady-state model and concerns the lower layer. The individual basin-fill aquifers underlying the various ground-water basins can be adequately described in the upper layer as a series of high-transmissivity zones (the basin-fill valleys) separated from each other by low-transmissivity zones (the intervening mountain ranges). The lower layer represents the distribution of carbonate-rock aquifers in the system in a limited way that may affect the calculated drawdowns in that layer.

The fourth and final assumption was that all input values used in the conceptual steady-state model remain constant during the transient simulations. No changes were made to transmissivity, leakance, recharge, or the other input data sets described by Prudic and others (1993) and Schaefer (1993).

\section{RESULTS OF SIMULATIONS}

\section{Simulation of Conditions Prior to Proposed Pumping}

The steady-state conditions simulated by Prudic and others (1993) represent a conceptualization of ground-water flow in the carbonate-rock province of the Great Basin before ground-water pumping within the province commenced. Figure 2 shows the general distribution of simulated steady-state heads (water 
levels) that were used as the starting heads for the transient simulations. Also shown in figure 2 is the general direction of ground-water flow for both the alluvial and carbonate aquifers. The starting-head data used in the transient model are listed in appendix 2 .

The highest simulated steady-state heads are generally in southwestern Utah and east-central Nevada. In these areas, altitudes of the valley floors are the highest and estimated recharge assigned to the mountains is the greatest. Heads generally decrease northward toward the Humboldt River and the Great Salt Lake, and southward toward the Colorado River and Death Valley. Ground-water flow follows a similar pattern-flow is away from areas of highest heads. Many geologic and hydrologic barriers compartmentalize flow into several regions. Flow within each region is discussed in detail by Prudic and others (1993).

\section{Proposed Pumping and Stress Periods}

The proposed pumpage was to increase for about 18 years, from a rate of $24,500 \mathrm{acre}-\mathrm{ft} / \mathrm{yr}$ to $180,800 \mathrm{acre}-\mathrm{ft} / \mathrm{yr}$, in four phased steps. Table 1 shows the overall pumping schedule and the amount of pumpage from each basin. These data are the basis for the pumpage simulated in the model. The model stress periods coincide with the proposed pumping phases of LVVWD, and the simulated pumpage in the model duplicates the areal distribution of the proposed well locations. Table 2 shows how these pumping periods relate to the model stress periods. Appendix 3 contains the pumpage data set used in the model.

\section{Simulated Effects of Proposed Pumping}

The simulated effects of pumping large quantities of ground water from east-central and southern Nevada include water-level declines, reductions in evapotranspiration and discharge from regional springs, and changes in flow to or from rivers, lakes, and the Death Valley playa. These results were calculated by the model, but because existing data are not adequate to allow the simulated results to be calibrated against observed changes, they contain a high degree of uncertainty. They should not be considered exact predictions of change but rather indications of possible generalized effects. The trends and magnitudes of the calculated changes are considered first approximations that can give valuable insight into possible regional effects of long-term, high-volume pumpage in the province.

\section{Simulated Pumpage and Drawdowns}

At selected time steps for all five stress periods of the simulation, water-level declines (drawdowns) were calculated for both layers by comparing waterlevel arrays of successive stress periods. Drawdown patterns for both model layers then were mapped and are shown for selected time periods in figures 4-10. The drawdown values were computed by subtracting the original starting head for each model cell from the corresponding head simulated at the end of each selected time step. Lines of equal drawdown for each time step were then produced using the Golden Software Company "Surfer" computer contouring package. Locations of the proposed pumping wells in each stress period are also plotted on the maps to show their relation to the simulated declines. Each map shows simulated drawdowns for a layer, and only those wells designated to produce from that layer during that stress period are shown.

A pumping well represents discharge at a point, but the model distributes the pumpage over a 5-mi by 7-1/2-mi cell. Because both aquifer properties and changes in water level are averaged over the entire grid cell, some error is introduced. Furthermore, the model "pumps" the cell for the entire stress period at the constant rate. In reality, this may not be so, as some type of site-specific pumping schedule might be used to minimize local effects. That level of detail was beyond the scope of the study.

The original applications for water rights by LVVWD included a list of proposed well locations, and indicated whether each well was to be completed in the basin fill or the carbonate aquifer. Also included was a list of total withdrawals in each ground-water basin. To create the pumpage data set for the model, it was necessary to determine the pumping rate for each well within each basin by dividing the total pumpage from that basin by the total number of wells. If a well was completed in the basin-fill aquifer, pumpage for the model was assigned to the upper layer. An identical process was used for wells proposed to be completed in the carbonate aquifer (and assigned to the lower layer). 
Table 1. Pumpage proposed by Las Vegas Valley Water District during first 20 years of pumping, by basin, eastcentral and southern Nevada

[Location of basins, by hydographic area, is shown in figure 3]

\begin{tabular}{|c|c|c|c|c|c|c|c|c|c|c|}
\hline \multirow[b]{2}{*}{$\begin{array}{l}\text { Proposed } \\
\text { pumpage } \\
\text { schedule }\end{array}$} & \multirow[b]{2}{*}{ Year } & \multicolumn{9}{|c|}{ Pumpage (acre-feet per year) by basin, and hydrographic-area (HA) number } \\
\hline & & $\begin{array}{c}\text { Garnet } \\
\text { (Dry Lake) } \\
\text { Valiey, } \\
\text { HA } 216\end{array}$ & $\begin{array}{l}\text { Hidden } \\
\text { Valley, } \\
\text { HA 217 }\end{array}$ & $\begin{array}{l}\text { Callfornia } \\
\text { Wash, } \\
\text { HA } 218\end{array}$ & $\begin{array}{l}\text { Coyote } \\
\text { Spring } \\
\text { Valley, } \\
\text { HA 210 }\end{array}$ & $\begin{array}{c}\text { Three } \\
\text { Lakes } \\
\text { Valley (S), } \\
\text { HA 211 }\end{array}$ & $\begin{array}{c}\text { Three } \\
\text { Lakes } \\
\text { Valley (N), } \\
\text { HA } 168\end{array}$ & $\begin{array}{l}\text { Tikapoo } \\
\text { Valley, } \\
\text { HA } 169 \\
\text { A and B }\end{array}$ & $\begin{array}{l}\text { Cave } \\
\text { Valley, } \\
\text { HA } 180\end{array}$ & $\begin{array}{l}\text { Coal } \\
\text { Valley, } \\
\text { HA } 171\end{array}$ \\
\hline \multirow[t]{7}{*}{ Phase 1} & 2007 & 2,000 & 2,000 & 2,500 & 5,000 & 5,000 & 5,000 & 3,000 & 0 & 0 \\
\hline & 2008 & 2,000 & 2,000 & 2,500 & 5,000 & 5,000 & 5,000 & 3,000 & 0 & 0 \\
\hline & 2009 & 2,000 & 2,000 & 2,500 & 5,000 & 5,000 & 5,000 & 3,000 & 0 & 0 \\
\hline & 2010 & 2,000 & 2,000 & 2,500 & 5,000 & 5,000 & 5,000 & 3,000 & 0 & 0 \\
\hline & 2011 & 2,000 & 2,000 & 2,500 & 5,000 & 5,000 & 5,000 & 3,000 & 0 & 0 \\
\hline & 2012 & 2,000 & 2,000 & 2,500 & 5,000 & 5,000 & 5,000 & 3,000 & 0 & 0 \\
\hline & 2013 & 2,000 & 2,000 & 2,500 & 5,000 & 5,000 & 5,000 & 3,000 & 0 & 0 \\
\hline \multirow[t]{4}{*}{ Phase 2} & 2014 & 2,000 & 2,000 & 2,500 & 5,000 & 5,000 & 5,000 & 3,000 & 2,000 & 6,000 \\
\hline & 2015 & 2,000 & 2,000 & 2,500 & 5,000 & 5,000 & 5,000 & 3,000 & 2,000 & 6,000 \\
\hline & 2016 & 2,000 & 2,000 & 2,500 & 5,000 & 5,000 & 5,000 & 3,000 & 2,000 & 6,000 \\
\hline & 2017 & 2,000 & 2,000 & 2,500 & 5,000 & 5,000 & 5,000 & 3,000 & 2,000 & 6,000 \\
\hline \multirow[t]{7}{*}{ Phase 3} & 2018 & 0 & 0 & 2,500 & 5,000 & 5,000 & 5,000 & 3,000 & 2,000 & 6,000 \\
\hline & 2019 & 0 & 0 & 2,500 & 5,000 & 5,000 & 5,000 & 3,000 & 2,000 & 6,000 \\
\hline & 2020 & 0 & 0 & 2,500 & 5,000 & 5,000 & 5,000 & 3,000 & 2,000 & 6,000 \\
\hline & 2021 & 0 & 0 & 2,500 & 5,000 & 5,000 & 5,000 & 3,000 & 2,000 & 6,000 \\
\hline & 2022 & 0 & 0 & 2,500 & 5,000 & 5,000 & 5,000 & 3,000 & 2,000 & 6,000 \\
\hline & 2023 & 0 & 0 & 2,500 & 5,000 & 5,000 & 5,000 & 3,000 & 2,000 & 6,000 \\
\hline & 2024 & 0 & 0 & 2,500 & 5,000 & 5,000 & 5,000 & 3,000 & 2,000 & 6,000 \\
\hline Phase 4 & 2025 & 0 & 0 & 2,500 & 5,000 & 5,000 & 5,000 & 3,000 & 2,000 & 6,000 \\
\hline
\end{tabular}

${ }^{1}$ Includes three wells that are physically located in Las Vegas Valley Hydrographic Area (212) but are considered by Las Vegas Valley Water District to be in Three Lakes Valley (southern part).

Figure 4 shows drawdown and wells for both layers at the end of 7 years of pumping (conclusion of stress-period one). Total annual pumpage during this phase of the water project is planned to be 24,500 acre-ft. Of this amount, 29 percent $(7,100 \mathrm{acre}-\mathrm{ft} / \mathrm{yr})$ was assigned to the upper layer, and 71 percent $(17,400$ acre- $\mathrm{ft} / \mathrm{yr})$ was assigned to the lower layer. Pumping is planned for Garnet (Dry Lake), Hidden, California Wash, Coyote Spring, Three Lakes, and Tikapoo Valleys (fig. 3). In the upper layer (fig. $4 A$ ), the drawdown exceeds $10 \mathrm{ft}$ only in Three Lakes Valley. Drawdowns are localized around the cells with assigned pumpage. Drawdowns in the lower layer (fig. $4 B$ ) are more extensive, showing a maximum decline of more than $100 \mathrm{ft}$ in several valleys. Boundaries of the topographic basins, which form the boundaries of the alluvial basins (upper layers), are not barriers to flow within the carbonate system (lower layers). Declines in the lower layer can extend far beyond the basin boundary because the model simulates the carbonate aquifer in the lower layer as being confined, and storage values are much less.

Figure 5 shows simulated drawdown and location of wells for both layers at the end of 11 years of pumping (conclusion of stress-period two). Total annual pumpage proposed for this phase of the project is 47,000 acre-ft. Of this amount, 39 percent $(18,300 \mathrm{acre}-\mathrm{ft} / \mathrm{yr})$ was assigned to the upper layer, and 61 percent $(28,700 \mathrm{acre}-\mathrm{ft} / \mathrm{yr})$ was assigned to the lower layer. During this phase of development, pumping wells will be added in Cave, Coal, Delamar, Dry Lake, Pahroc, and Patterson Valleys (fig. 3). 
Table 1-Continued

\begin{tabular}{|c|c|c|c|c|c|c|c|c|}
\hline \multicolumn{9}{|c|}{ Pumpage (acre-feet per year) by basin, and hydrographic area (HA) number } \\
\hline $\begin{array}{l}\text { Delamar } \\
\text { Valley, } \\
\text { HA } 182\end{array}$ & $\begin{array}{c}\text { Dry Lake } \\
\text { Valley, } \\
\text { HA } 181\end{array}$ & $\begin{array}{l}\text { Pahroc } \\
\text { Valley, } \\
\text { HA 208 }\end{array}$ & $\begin{array}{c}\text { Patterson } \\
\text { Valley, } \\
\text { HA } 202\end{array}$ & $\begin{array}{l}\text { Snake } \\
\text { Valley, } \\
\text { HA } 195\end{array}$ & $\begin{array}{l}\text { Spring } \\
\text { Valley, } \\
\text { HA } 184\end{array}$ & $\begin{array}{l}\text { Garden } \\
\text { Valley, } \\
\text { HA } 172\end{array}$ & $\begin{array}{c}\text { Railroad } \\
\text { Valley, } \\
\text { HA } 173 \\
A \text { and B }\end{array}$ & $\begin{array}{c}\text { Total } \\
\text { (acre-feet } \\
\text { per year) }\end{array}$ \\
\hline 0 & 0 & 0 & 0 & 0 & 0 & 0 & 0 & 24,500 \\
\hline 0 & 0 & 0 & 0 & 0 & 0 & 0 & 0 & 24,500 \\
\hline 0 & 0 & 0 & 0 & 0 & 0 & 0 & 0 & 24,500 \\
\hline 0 & 0 & 0 & 0 & 0 & 0 & 0 & 0 & 24,500 \\
\hline 0 & 0 & 0 & 0 & 0 & 0 & 0 & 0 & 24,500 \\
\hline 0 & 0 & 0 & 0 & 0 & 0 & 0 & 0 & 24,500 \\
\hline 0 & 0 & 0 & 0 & 0 & 0 & 0 & 0 & 24,500 \\
\hline 3,000 & 2,500 & 5,000 & 4,000 & 0 & 0 & 0 & 0 & 47,000 \\
\hline 3,000 & 2,500 & 5,000 & 4,000 & 0 & 0 & 0 & 0 & 47,000 \\
\hline 3,000 & 2,500 & 5,000 & 4,000 & 0 & 0 & 0 & 0 & 47,000 \\
\hline 3,000 & 2,500 & 5,000 & 4,000 & 0 & 0 & 0 & 0 & 47,000 \\
\hline 3,000 & 2,500 & 5,000 & 4,000 & 25,000 & 50,000 & 0 & 0 & 118,000 \\
\hline 3,000 & 2,500 & 5,000 & 4,000 & 25,000 & 50,000 & 0 & 0 & 118,000 \\
\hline 3,000 & 2,500 & 5,000 & 4,000 & 25,000 & 50,000 & 0 & 0 & 118,000 \\
\hline 3,000 & 2,500 & 5,000 & 4,000 & 25,000 & 50,000 & 0 & 0 & 118,000 \\
\hline 3,000 & 2,500 & 5,000 & 4,000 & 25,000 & 50,000 & 0 & 0 & 118,000 \\
\hline 3,000 & 2,500 & 5,000 & 4,000 & 25,000 & 50,000 & 0 & 0 & 118,000 \\
\hline 3,000 & 2,500 & 5,000 & 4,000 & 25,000 & 50,000 & 0 & 0 & 118,000 \\
\hline 3,000 & 2,500 & 5,000 & 4,000 & 25,000 & 50,000 & 10,000 & 52,800 & 180,800 \\
\hline
\end{tabular}

Figure $5 A$ shows an increase in the areal extent of simulated drawdowns in the upper layer, but maximum declines do not increase appreciably. The additional wells pumped during this phase of the simulation cause new declines in those additional areas. The simulated drawdowns in the lower layer (fig. $5 B$ ) likewise show an increase in areal extent and the maximum drawdowns have increased in some areas.

Figure 6 shows the simulated drawdowns for both layers at the end of 18 years of pumping (conclusion of time-step two, stress-period three). Pumpage during this stress period was set at 118,000 acre-ft/yr. Of this amount, 61 percent was assigned to the upper layer (72,000 acre-ft/yr), and 39 percent $(46,000$ acre-ft/yr) was assigned to the lower layer. During this stress period, pumping was from California Wash and from Coyote Spring, Three Lakes, Tikapoo, Cave, Coal, Delamar, Dry Lake, Pahroc, Patterson, Snake, and
Spring Valleys. Pumping was terminated in Garnet (Dry Lake) Valley and Hidden Valley at the start of this stress period.

In the upper layer (fig. $6 A$ ), maximum simulated declines exceed $100 \mathrm{ft}$ in the area of Three Lakes Valley. Simulated declines exceed $50 \mathrm{ft}$ in Spring Valley. Simulated declines in the lower layer (fig. 6B) are areally more extensive and are beginning to affect a large area of the carbonate-rock province. Simulated drawdown exceeds $100 \mathrm{ft}$ in Spring, Snake, and probably in other valleys. Simulated drawdowns do not generally exceed $200 \mathrm{ft}$, with the exception of a localized maximum drawdown of about $400 \mathrm{ft}$ in the California Wash area. Declines induced by pumping in this area and in the Coyote Spring Valley area to the northwest seem to cause the drawdowns in the Muddy River springs area. 
Table 2. Simulated stress periods and pumpage, east-central and southern Nevada [Asterisks indicate key simulation lengths used for analysis; acre-ft/yr, acre-feet per year]

\begin{tabular}{lccc}
\hline \multicolumn{1}{c}{ Stress period } & $\begin{array}{c}\text { Time } \\
\text { step }\end{array}$ & $\begin{array}{c}\text { Length of time } \\
\text { step (years) }\end{array}$ & $\begin{array}{c}\text { Cumulative length } \\
\text { of simulation } \\
\text { (years) }\end{array}$ \\
\hline Stress-period one (Phase 1) & 1 & 3.5 & 3.5 \\
2007-2013 (7 years) & 2 & 3.5 & $* 7.0$ \\
Total pumpage, 24,500 acre-ft/yr & & & \\
Stress-period two (Phase 2) & 1 & 2.0 & 9.0 \\
2014-2017 (4 years) & 2 & 2.0 & $* 11.0$ \\
Total pumpage, 47,000 acre-ft/yr & & & \\
Stress-period three (Phase 3) & 1 & 3.5 & 14.5 \\
2018-2024 (7 years) & 2 & 3.5 & $* 18.0$ \\
Total pumpage, 118,000 acre-ft/yr & & & \\
Stress-period four (Phase 4) & 1 & 4.0 & 22.0 \\
2025-2036 (12 years) & 2 & 4.0 & 26.0 \\
Total pumpage, 180,800 acre-ft/yr & 3 & 4.0 & $* 30.0$ \\
& & & 42.3 \\
Stress-period five (Phase 4--continued) & 1 & 12.3 & 55.4 \\
2037-? & 2 & 25.4 & 84.5 \\
Total pumpage, 180,800 acre-ft/yr & 3 & 39.5 & $* 100.7$ \\
& 4 & 54.6 & 117.9 \\
& 5 & 70.7 & 136.4 \\
& & & 156.1 \\
& 6 & 87.9 & 177.3 \\
& 7 & 106.4 & $* 199.9$ \\
\hline
\end{tabular}

Figure 7 shows the simulated drawdowns due to pumping in the upper and lower layers 30 years into the model simulation (end of time-step three, stressperiod four). Total annual pumpage during this period of the simulation is $180,800 \mathrm{acre}-\mathrm{ft} / \mathrm{yr}$. This amount is the projected maximum pumpage rate for the water project. Pumpage is from California Wash and Coyote Spring, Three Lakes, Tikapoo, Cave, Coal, Delamar, Dry Lake, Pahroc, Patterson, Snake, and Spring Valleys. This is also the stress period when pumping begins in Railroad Valley at a rate of 52,800 acre- $\mathrm{ft} / \mathrm{yr}$ and in Garden Valley at a rate of $10,000 \mathrm{acre}-\mathrm{ft} / \mathrm{yr}$ (phase four; table 1). Of the total amount, 62 percent $(112,100 \mathrm{acre}-\mathrm{ft} / \mathrm{yr})$ was assigned to the upper layer and 38 percent $(68,700$ acre-ft/yr) was assigned to the lower layer.
Figure $7 A$ shows the simulated drawdowns in the upper layer. In the area of Three Lakes Valley, in the southern part of the pumping area, maximum drawdown is more than $100 \mathrm{ft}$. In Spring Valley, in the northern part of the pumping area, simulated drawdowns also exceed $100 \mathrm{ft}$. Throughout most of the pumping area by the end of stress-period four, simulated drawdowns exceed $1 \mathrm{ft}$. Simulated drawdowns exceeding $10 \mathrm{ft}$ have extended throughout much of the area. This stress period is the first indication of simulated drawdowns extending into the state of Utah.

Figure $7 B$ shows the declines produced in the lower layer resulting from the proposed pumpage. Several large areas of declines have developed coincident with large pumping centers. Drawdowns exceeding $100 \mathrm{ft}$ have developed in virtually all of the valleys. 
The maximum simulated drawdown of about $670 \mathrm{ft}$ is in Garden Valley. The areas of heaviest pumpageRailroad, Spring, Snake, and Garden Valleys-also are the areas of largest declines in water levels.

Stress-period five represents an extrapolation of the proposed pumping schedule to illustrate possible future effects. The model was set up so that the simulation time steps within this stress period could be divided into discrete intervals. Within stress-period five, the ten time steps were increased in length geometrically. This allowed a reasonable view of changes in the model without generating large amounts of output. From these ten time steps, two durations100 and 200 years - were selected for analysis of drawdowns and model budgets. The cumulative length of simulation at the end of stress-period five is 200 years.

Figure 8 shows the simulated drawdowns in both layers of the model after about 100 years into the simulation (time-step five, stress-period five). The total pumpage at this point in the simulation was still $180,800 \mathrm{acre}-\mathrm{ft} / \mathrm{yr}$. Of the total amount of pumpage, 62 percent was assigned to the upper layer and 38 percent was assigned to the lower layer.

Figure $8 \mathrm{~A}$ shows the simulated drawdowns in the upper layer. The simulated drawdowns have continued to expand from the previous analysis time period because pumping has remained constant and at the same locations. Simulated drawdowns in Tikapoo Valley have continued to increase, as well as those in Railroad Valley - which have exceeded $100 \mathrm{ft}$. Simulated drawdowns in the Snake and Spring Valley areas have expanded outward and deepened to a maximum of about $350 \mathrm{ft}$, and the area of 10- $\mathrm{ft}$ drawdowns has extended into Utah. Finally, simulated drawdowns in Garden Valley have also expanded areally, but have not increased vertically.

Simulated drawdowns in the lower layer (fig. $8 B$ ) have begun to stabilize, with small increases areally and vertically in the Coal and Garden Valley areas. A quasi-equilibrium apparently is being approached in the lower layer. Maximum drawdown is about $900 \mathrm{ft}$ in Garden Valley.

Figure 9 shows the simulated drawdowns in both the upper and lower layers after about 200 years into the simulation (time-step ten, stress-period five). Total annual pumpage continues to be 180,800 acre-ft. Pumpage is still divided between the upper and lower layers, as in the previous stress period. Areal distribution of pumping cells is the same as in the previous stress period.

Simulated drawdowns in the upper layer (fig. 9A), have continued to increase in many places. Pumping in Railroad and Three Lakes Valley areas has increased the simulated drawdowns. Pumping in Snake and Spring Valleys has resulted in substantial simulated drawdowns near Baker, with a maximum of about $450 \mathrm{ft}$. Many of the isolated cones of depression are merging to form larger, composite cones of depression.

Simulated drawdowns in the lower layer (fig. 9B) have also increased areally and in magnitude. Pumpage in the lower layer in Railroad, Snake, Pahroc, Three Lakes, and Tikapoo Valleys has resulted in three large cones of depression, each greater than $100 \mathrm{ft}$ and reaching more than $900 \mathrm{ft}$ in Garden Valley.

Figure 10 shows the simulated drawdowns in the upper and lower layers for the final steady-state simulation. The model has attained a simulated hydrologic equilibrium. The water that supplies the simulated pumping has ceased to come from storage; rather, it is water that formerly discharged to springs and as ET. Pumpage remains constant and distribution is somewhat similar to that in figure 9. Simulated drawdowns in the upper layer (fig. 10A) have expanded areally and have deepened. In the upper layer (fig. 10A), maximum simulated drawdown has exceeded $500 \mathrm{ft}$ in Railroad, Snake, Three Lakes, Cave, and Patterson Valleys. In Three Lakes Valley (northern part), the maximum drawdown is about $1,600 \mathrm{ft}$ because of simulated pumping in one cell. In the lower layer, simulated drawdowns exceed $100 \mathrm{ft}$ in most of the area and exceed $500 \mathrm{ft}$ in parts of Railroad, Garden, and Snake Valleys. Maximum drawdown in Garden Valley is about $1,100 \mathrm{ft}$.

Simulated drawdowns in specific cells were examined as part of the analysis of the effects of pumping on the regional ground-water flow system. The locations of these selected cells are shown in relation to the model grid in figure 11. These cells are generally near areas in which many of the DOI bureaus have specific water-resource concerns. These cells act as observation points, but in reality cover $37.5 \mathrm{mi}^{2}$ of surface area. They are useful in indicating trends in simulated ground-water levels in the area at any given time step. 


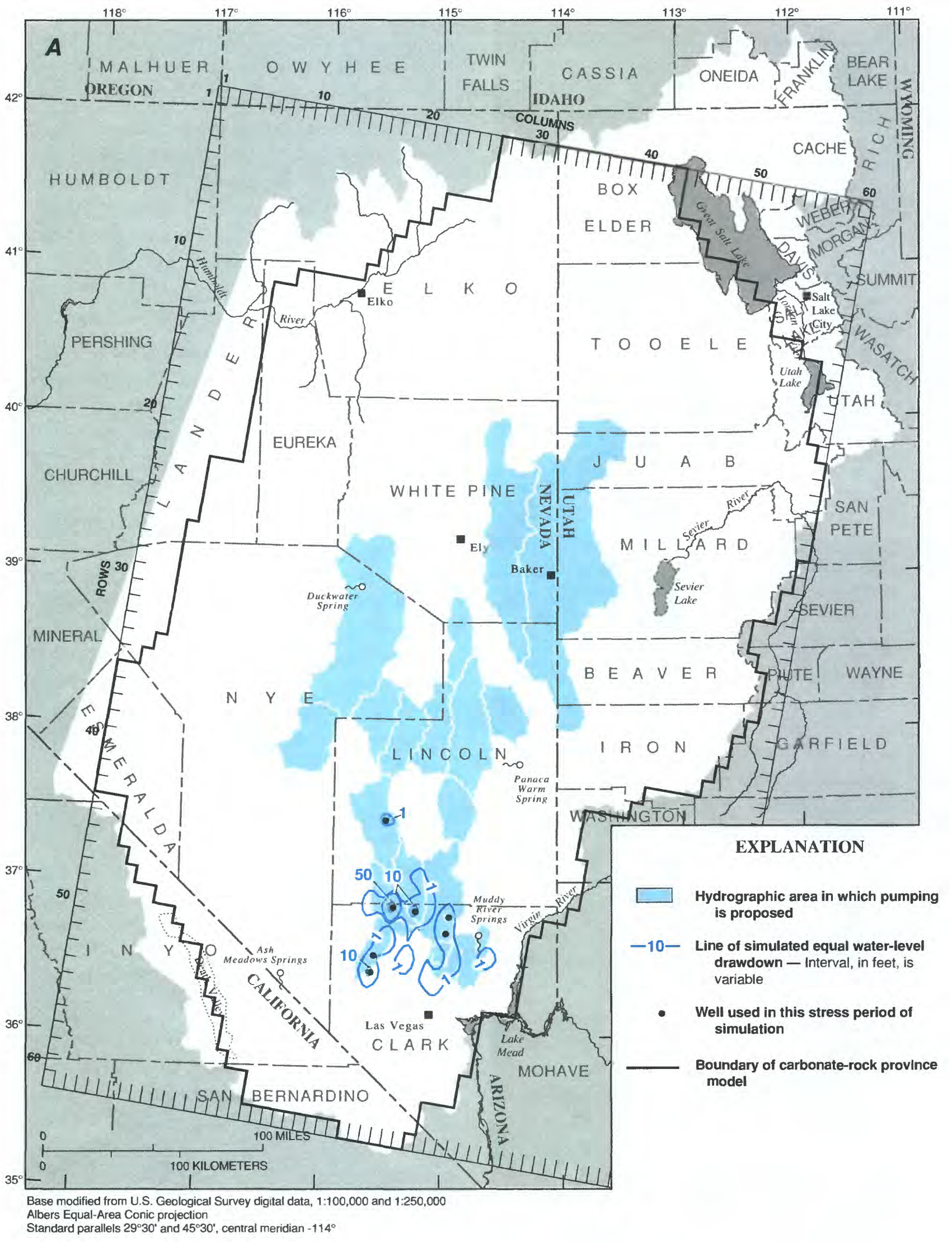

Figure 4. Simulated water-level drawdowns, stress period one, time-step two, after 7 years into simulation for (A) upper model layer and (B) lower model layer. 


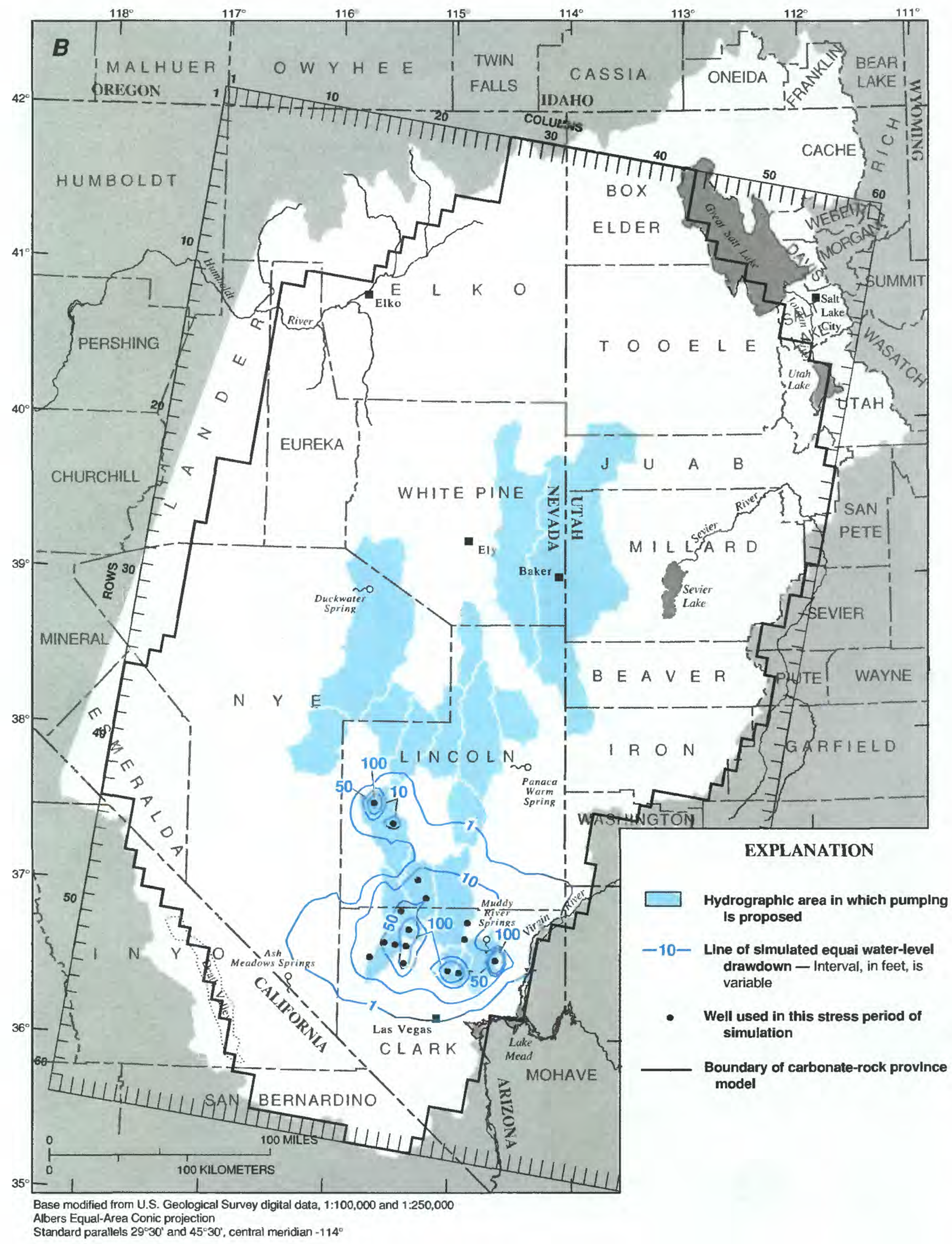

Figure 4. Continued. 


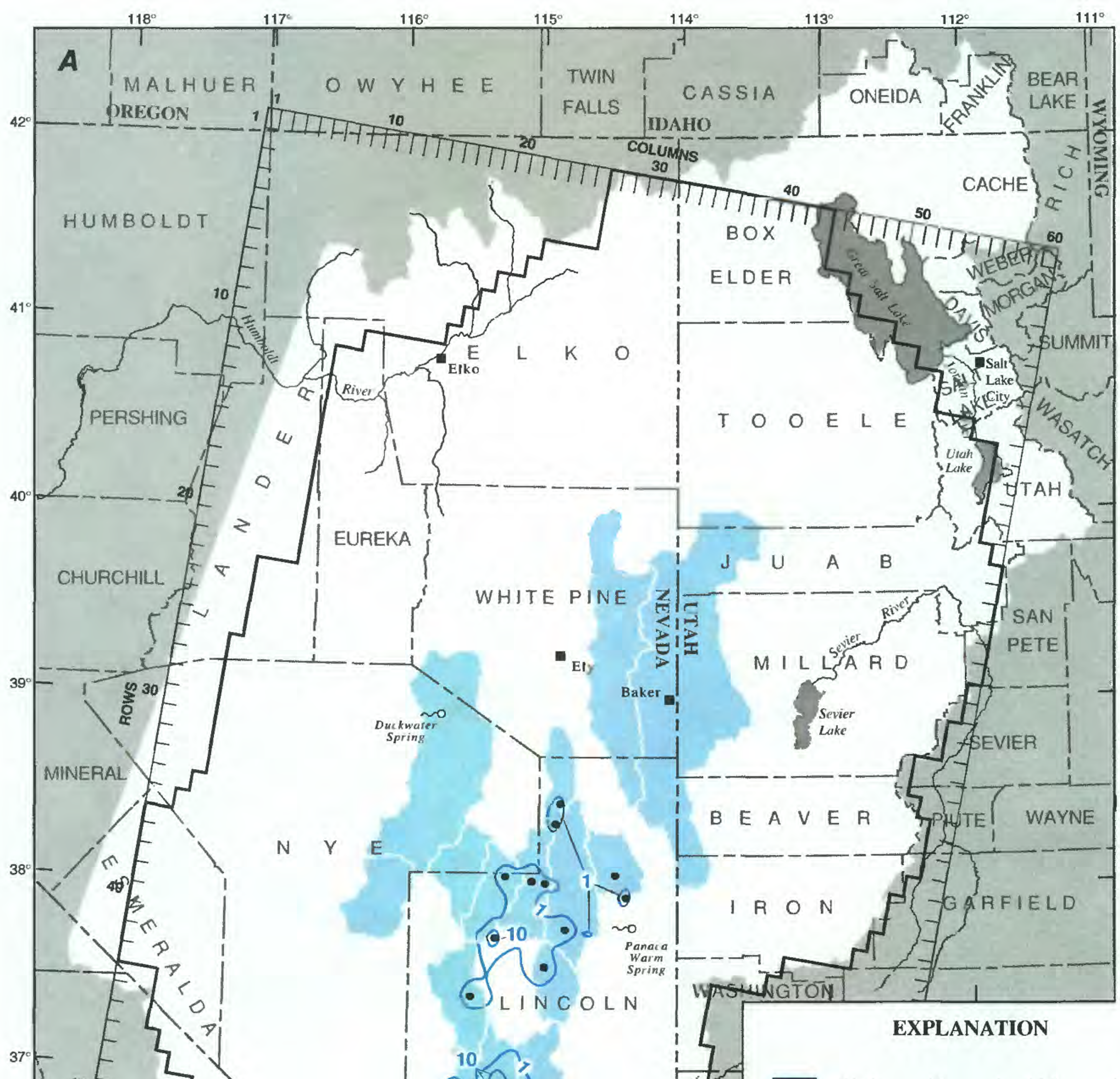

ydrographic area in which pumping is proposed

-10- Line of simulated equal water-level drawdown - Interval, in feet, is variable

- Well used in this stress perlod of simuiation

Boundary of carbonate-rock province model

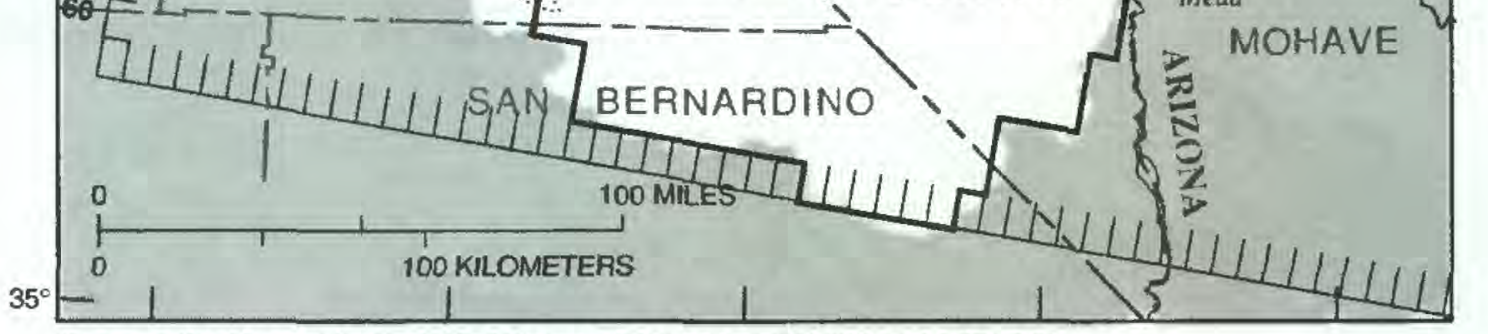

Base modified from U.S. Geological Survey digital data, 1:100,000 and 1:250,000 Albers Equal-Area Conic projection

Standard parallels $29^{\circ} 30^{\prime}$ and $45^{\circ} 30^{\circ}$, central mendian $-114^{\circ}$

Figure 5. Simulated water-level drawdowns, stress-period two, time-step two, after 11 years into simulation for (A) upper model layer and (B) lower model layer. 


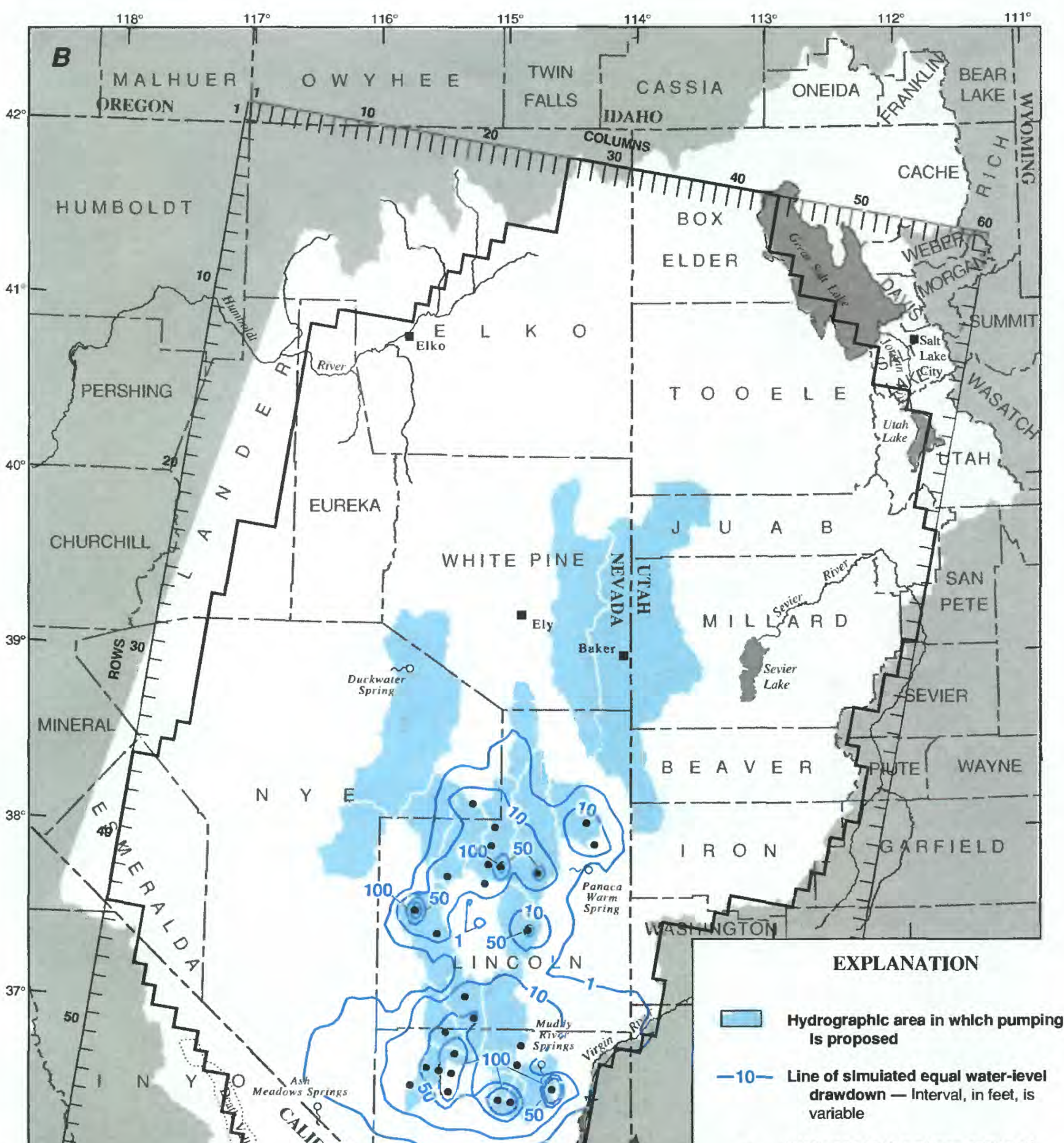

- Weli used In this stress period of simulation

Boundary of carbonate-rock provinca modei 


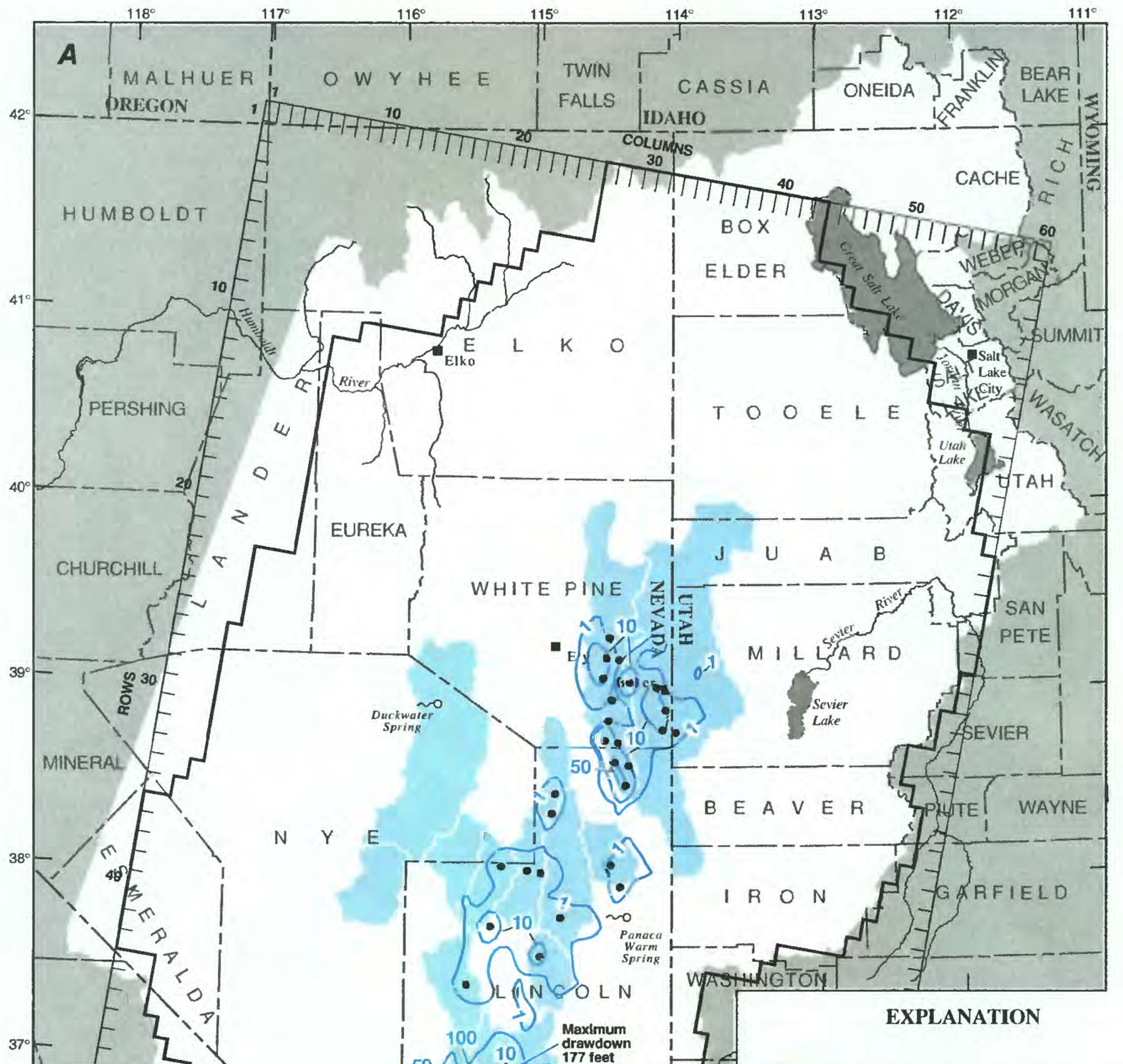

ydrographic area in which pumping is proposad

-10- Line of simulated equal water-leve drawdown - Interval, in feet, is variable

- Well used in this stress perlod of simulation

Boundary of carbonata-rock province model

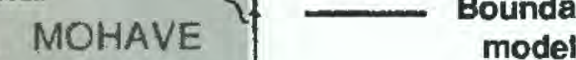

$35^{\circ}$

Base modified from U.S. Geological Survey digital data, 1:100,000 and 1:250,000

Albers Equal-Area Conic projection

Standard parallels $29^{\circ} 30^{\circ}$ and $45^{\circ} 30^{\circ}$. central meridian $-114^{\circ}$

Figure 6. Simulated water-level drawdowns, stress-period three, time-step two, after 18 years into simulation for (A) upper model layer and (B) lower model layer. 


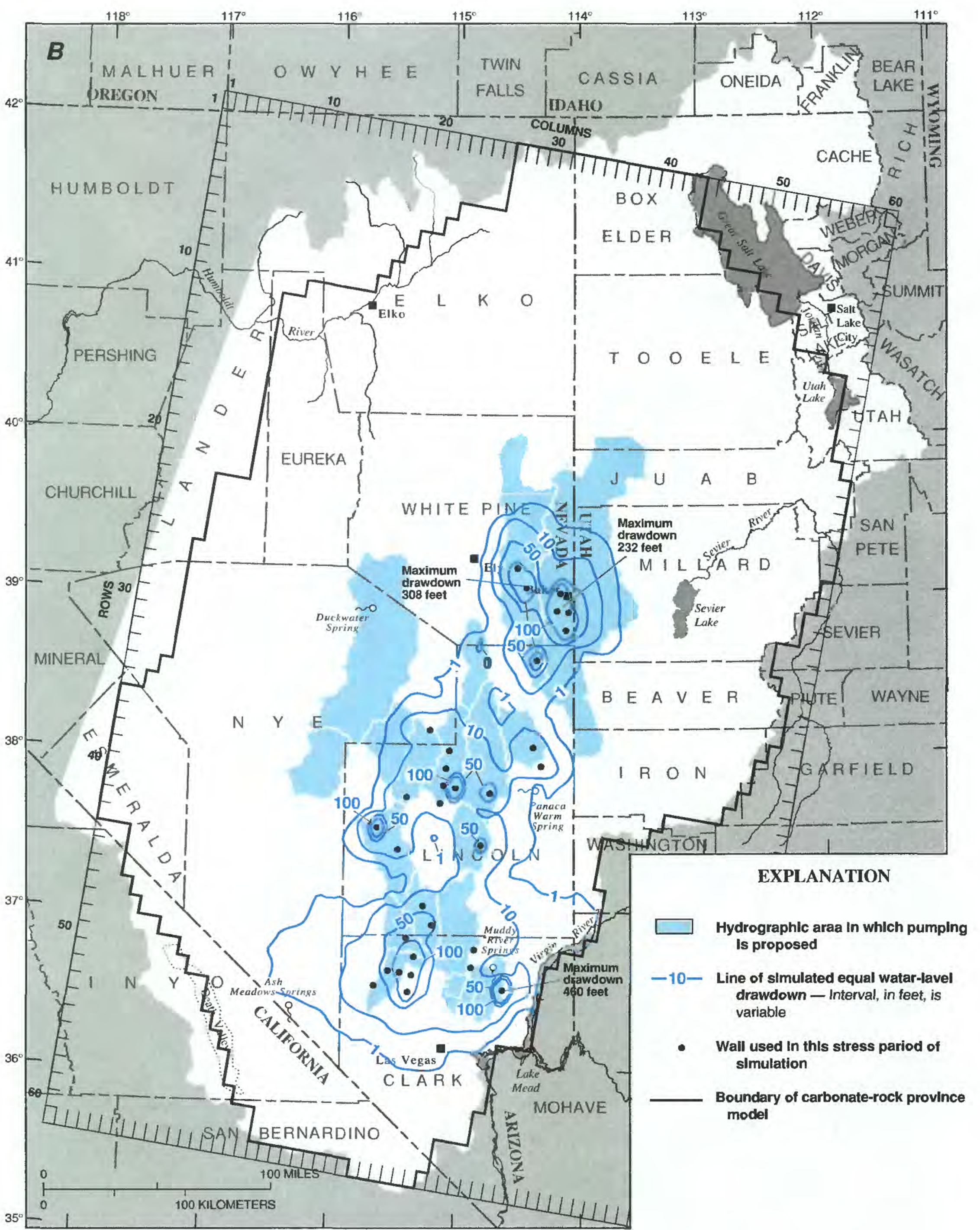

Base modified from U.S. Geological Survey digital data, 1:100,000 and $1: 250,000$

Albers Equal-Area Conic projection

Standard parallels $29^{\circ} 30^{\prime}$ and $45^{\circ} 30^{\circ}$, central meridian $-114^{\circ}$

Figure 6. Continued. 

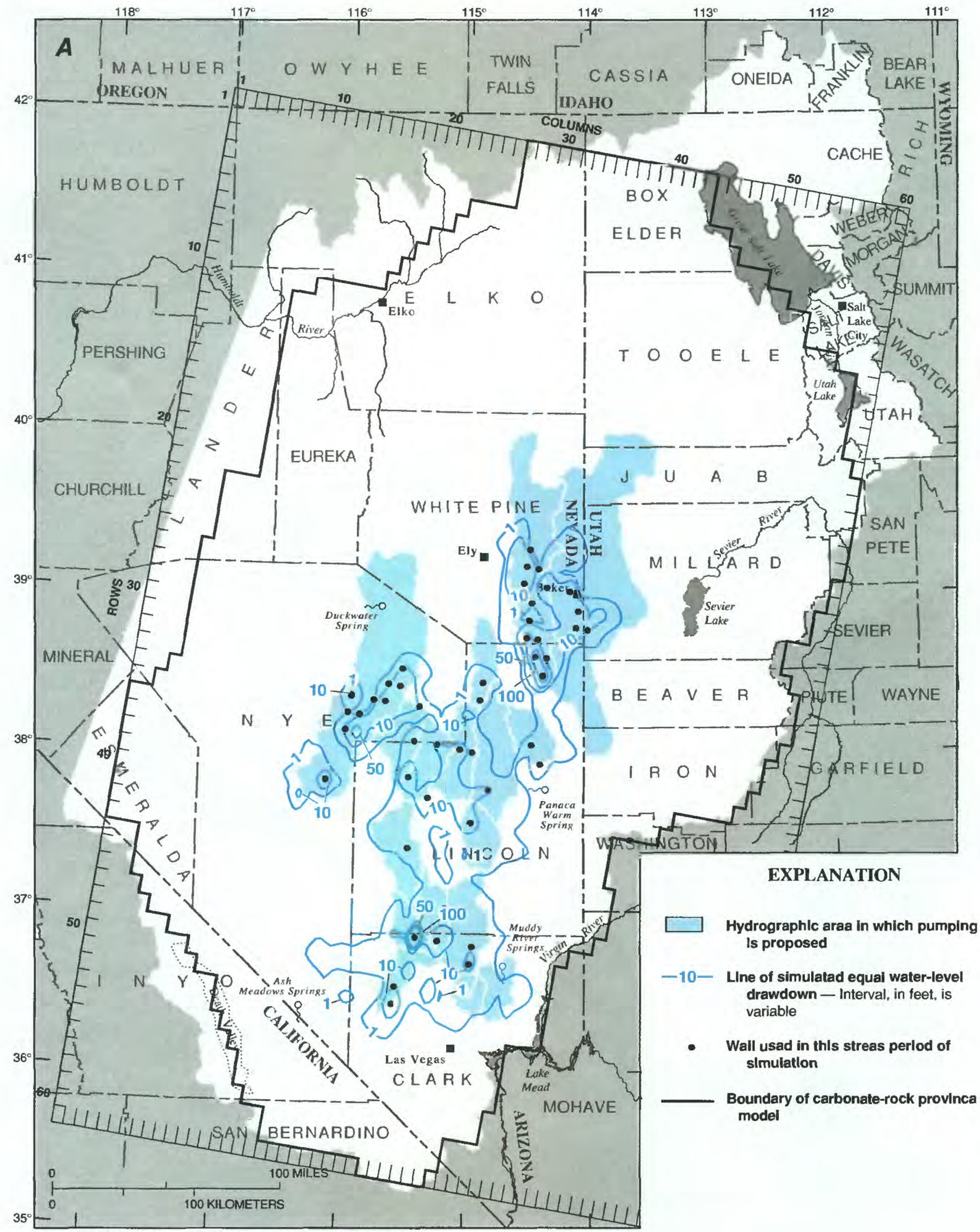

Base modified from U.S. Geological Survey digital data, 1:100,000 and 1:250,000

Albers Equal-Area Conic projection

Standard parallels $29^{\circ} 30^{\prime}$ and $45^{\circ} 30^{\circ}$. central meridian $-114^{\circ}$

Figure 7. Simulated water-level drawdowns, stress-period four, time-step three, after 30 years into simulation for (A) upper model layer and (B) lower model layer. 

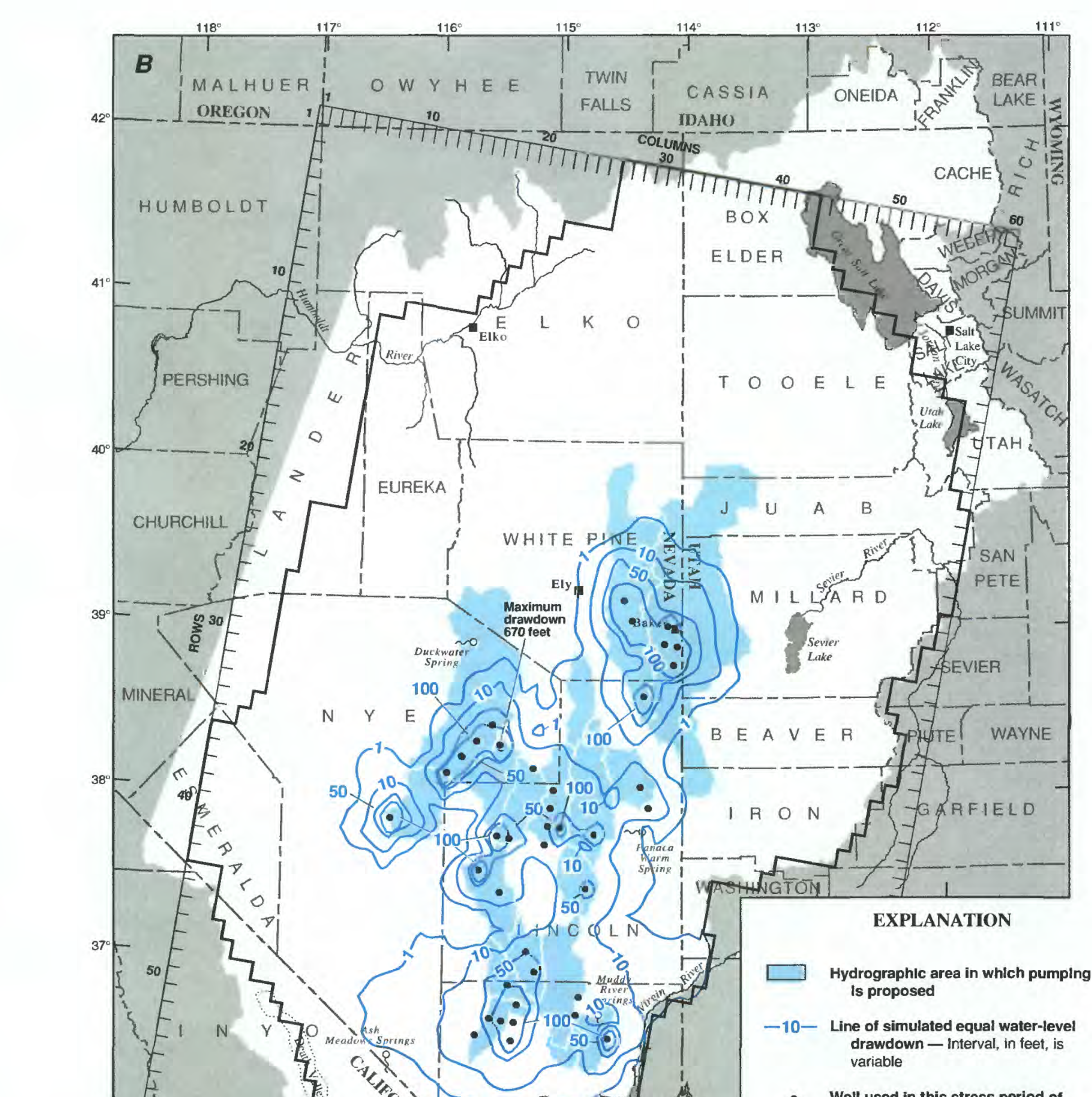

.

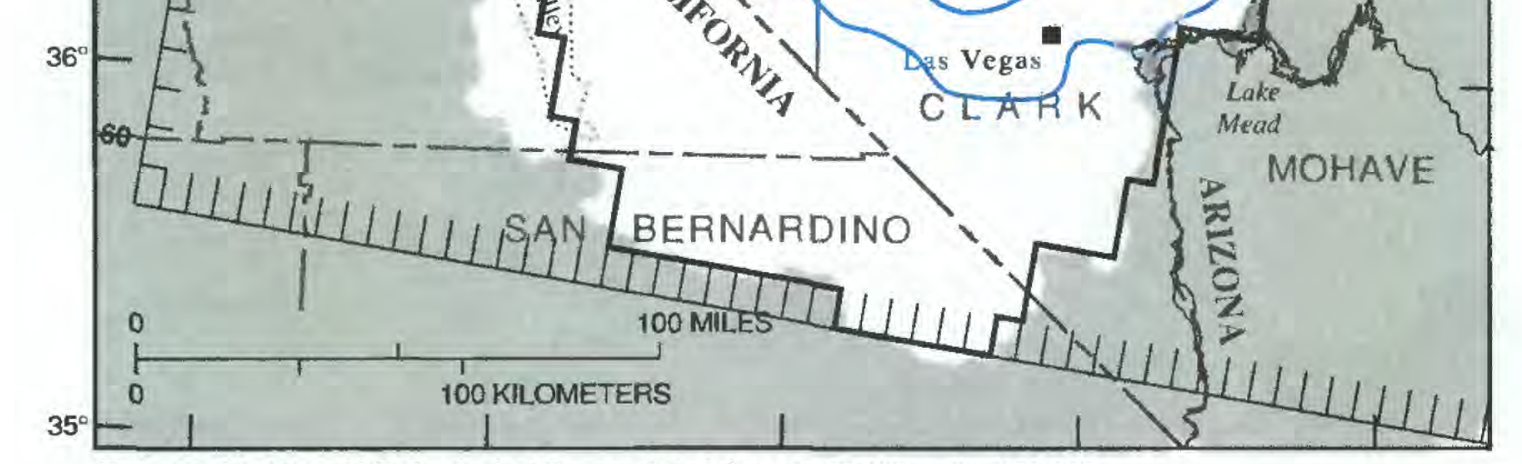

- Well used in this stress period of simulation

Boundary of carbonate-rock province model

Base modified from U.S. Geological Survey digital data, 1:100,000 and 1:250,000

Albers Equal-Area Conic projection

Siandard parallels $29^{\circ} 30^{\prime}$ and $45^{\circ} 30^{\prime}$, central meridian $-114^{\circ}$

Figure 7. Continued. 


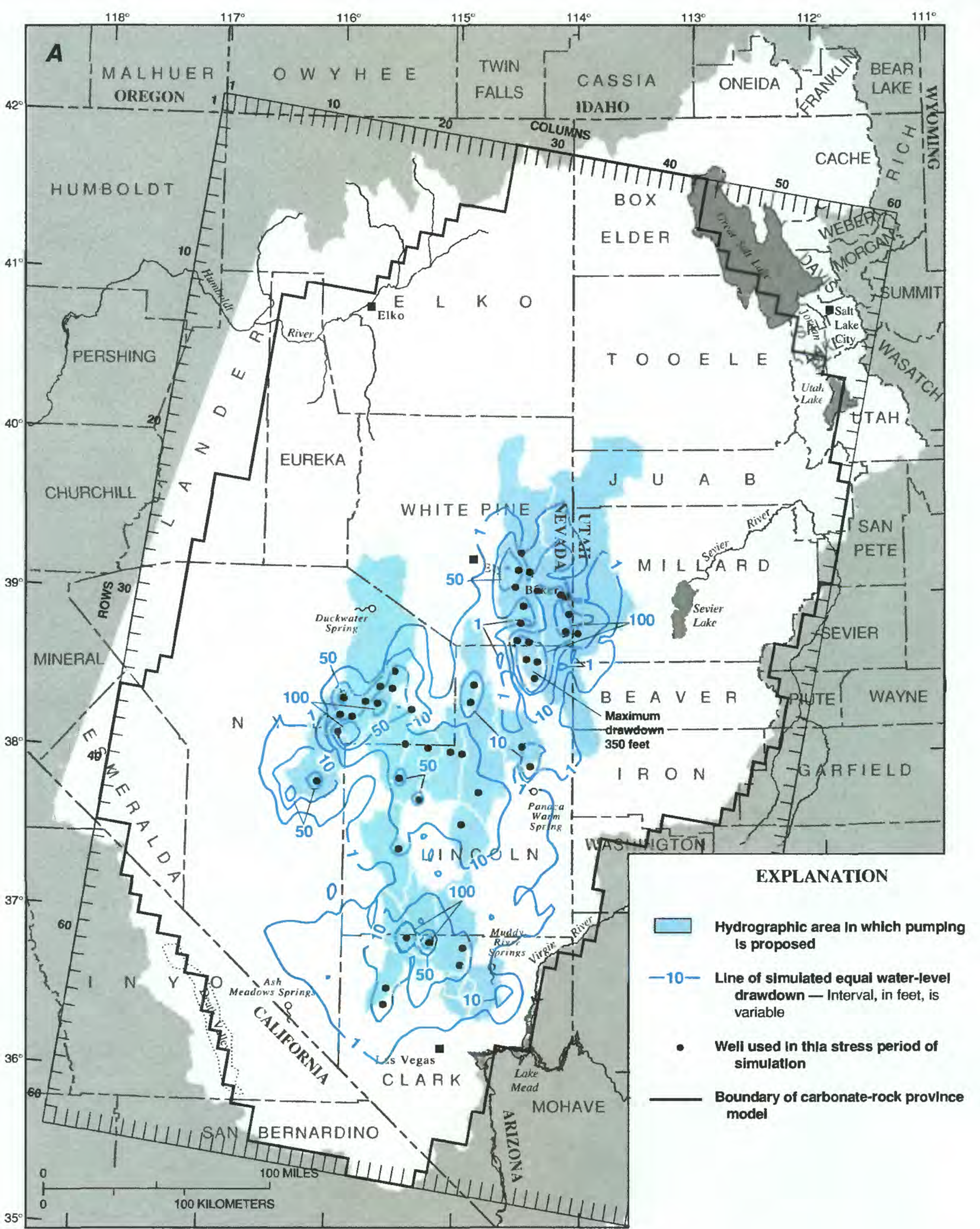

Base modified from U.S. Geological Survey digital data, 1:100,000 and 1:250,000 Albers Equal-Area Conic projection

Standard parallels $29^{\circ} 30^{\prime}$ and $45^{\circ} 30^{\prime}$, central meridian $-114^{\circ}$

Figure 8. Simulated water-level drawdowns, stress-period five, time-step five, after 100.7 years into simulation for (A) upper model layer and (B) lower model layer. 


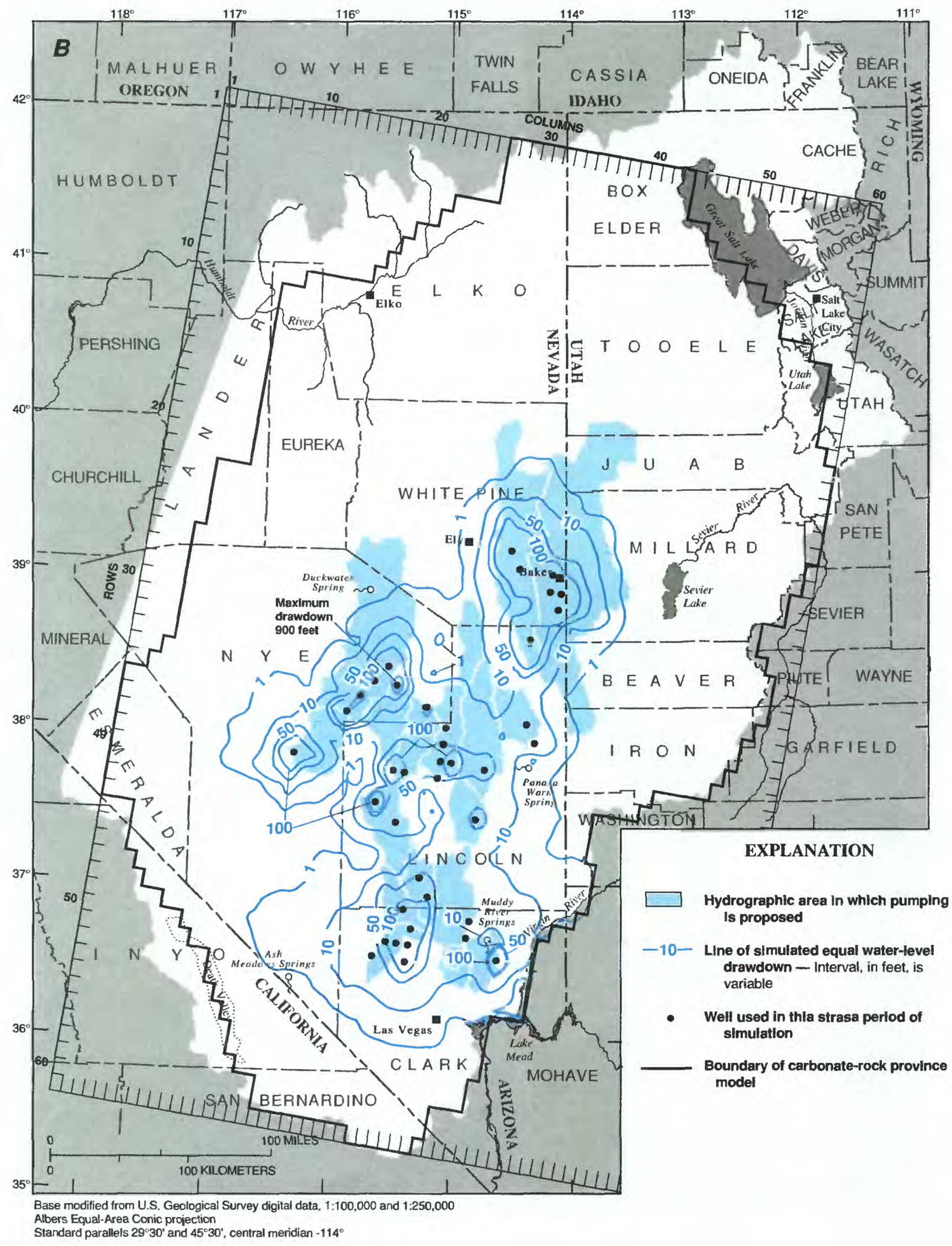

Figure 8. Continued. 


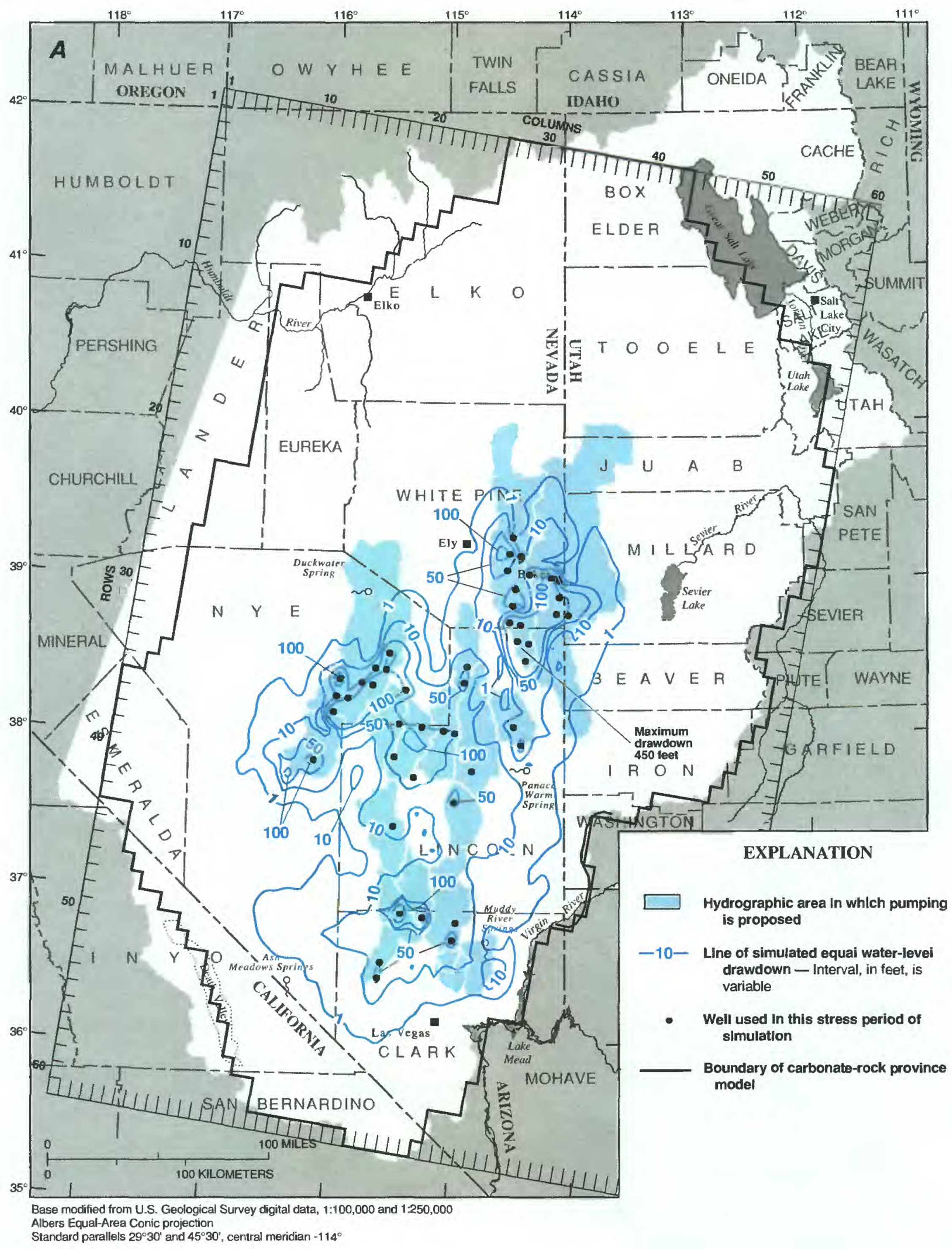

Figure 9. Simulated water-level drawdowns, stress-period five, time-step ten, after 199.9 years into simulation for (A) upper model layer and (B) lower model layer. 


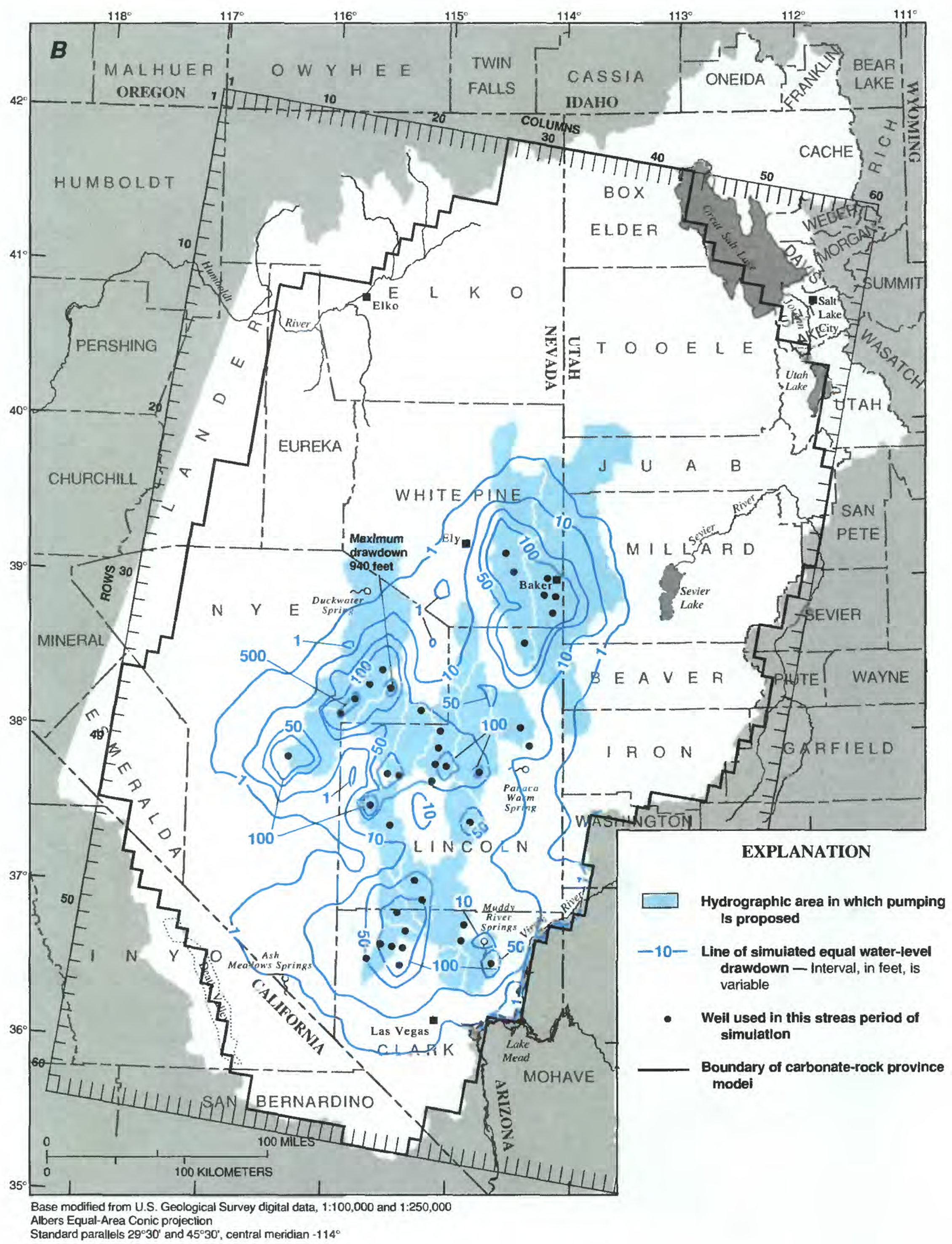

Figure 9. Continued. 


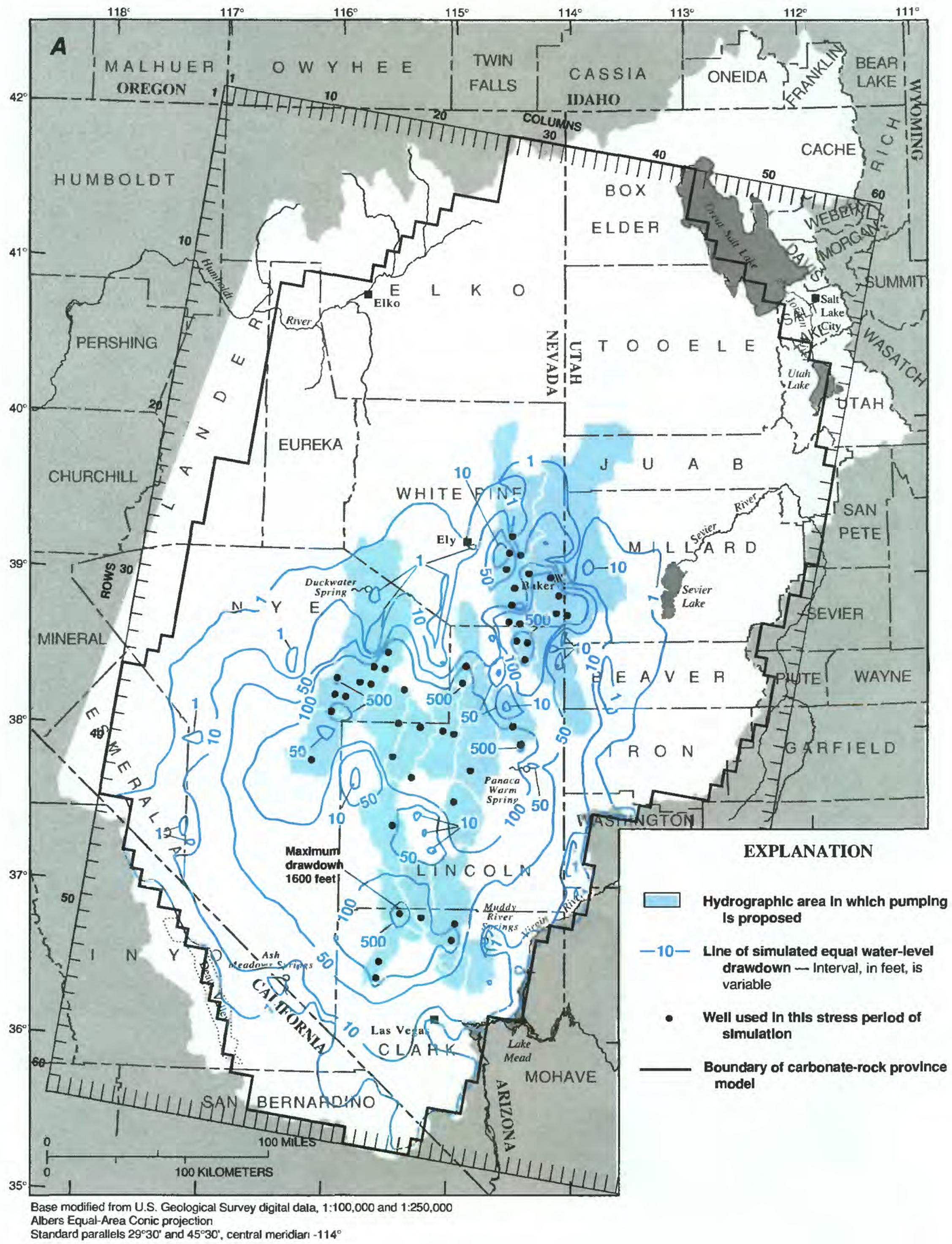

Figure 10. Simulated water-level drawdowns at final steady-state simulation for $(A)$ upper model layer and (B) lower model layer. 


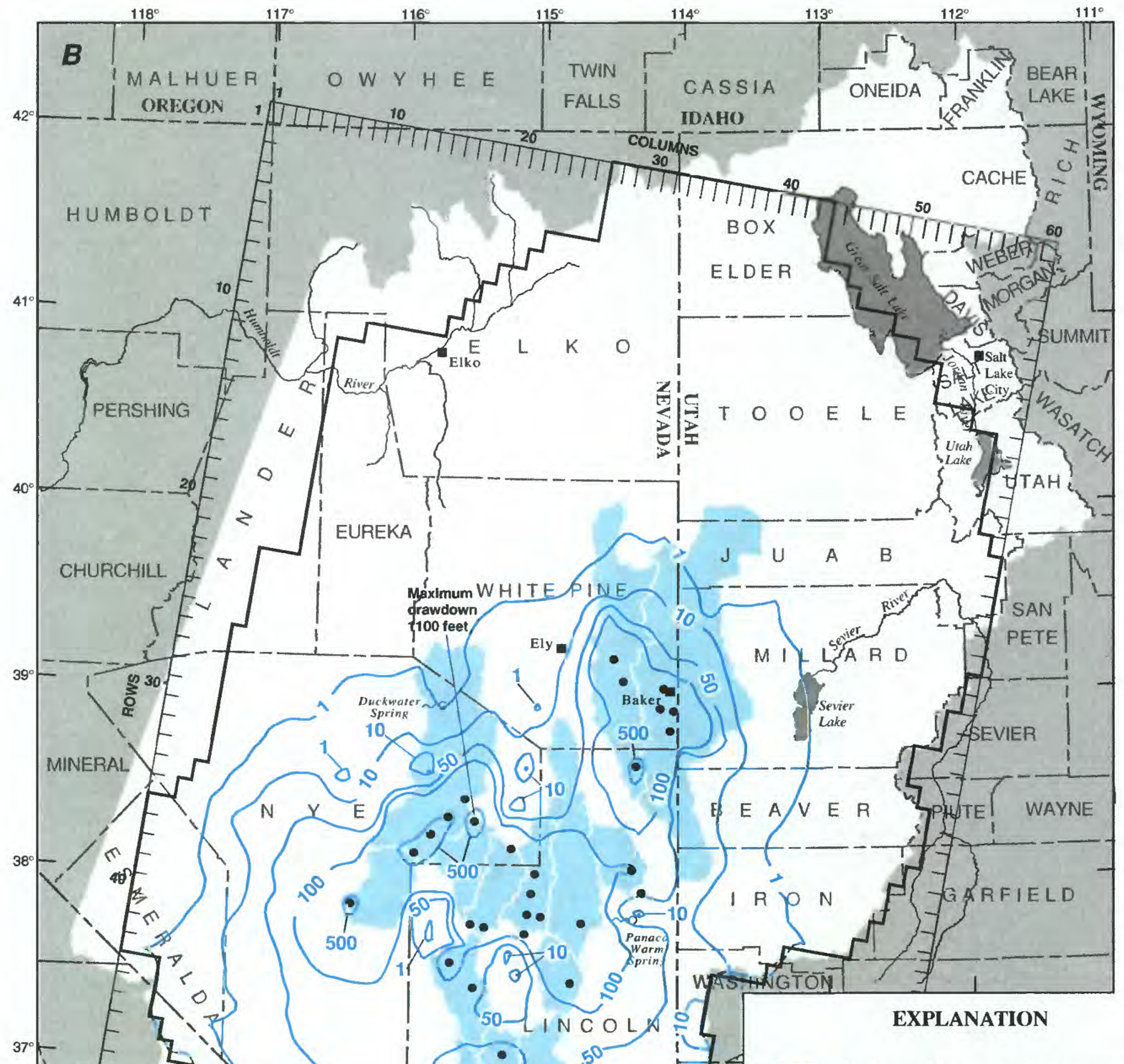

Hdrographic area in which pumping Is proposed

-10 - Line of simulated equal water-level drawdown - Interval, in feet, is variable

- Well used in this streas perlod of simulation

Boundary of carbonate-rock province model

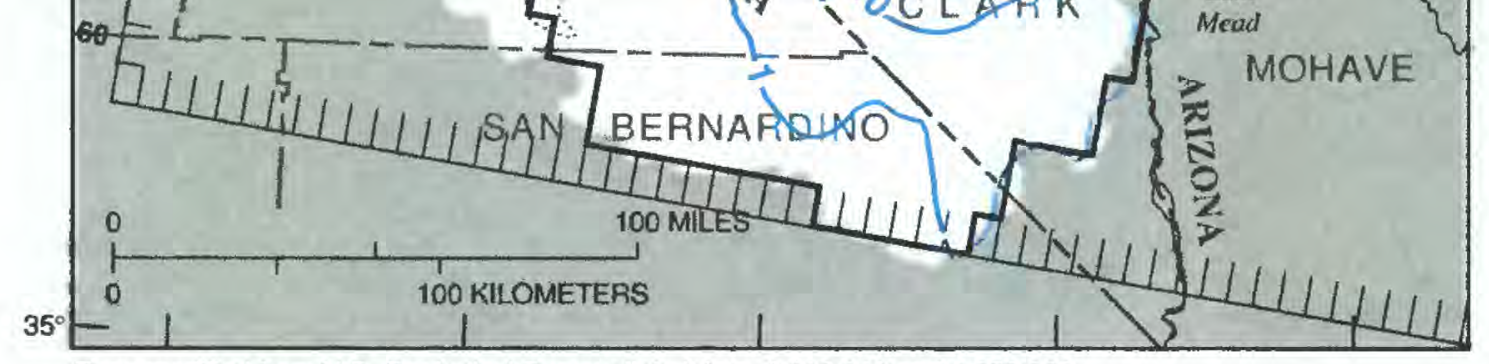

Base modified from U.S. Geological Survey digital data, 1:100,000 and 1:250,000

Albers Equal-Area Conic projection

Standard parallels $29^{\circ} 30^{\prime}$ and $45^{\circ} 30^{\prime}$, central meridian $-114^{\circ}$

Figure 10. Continued. 

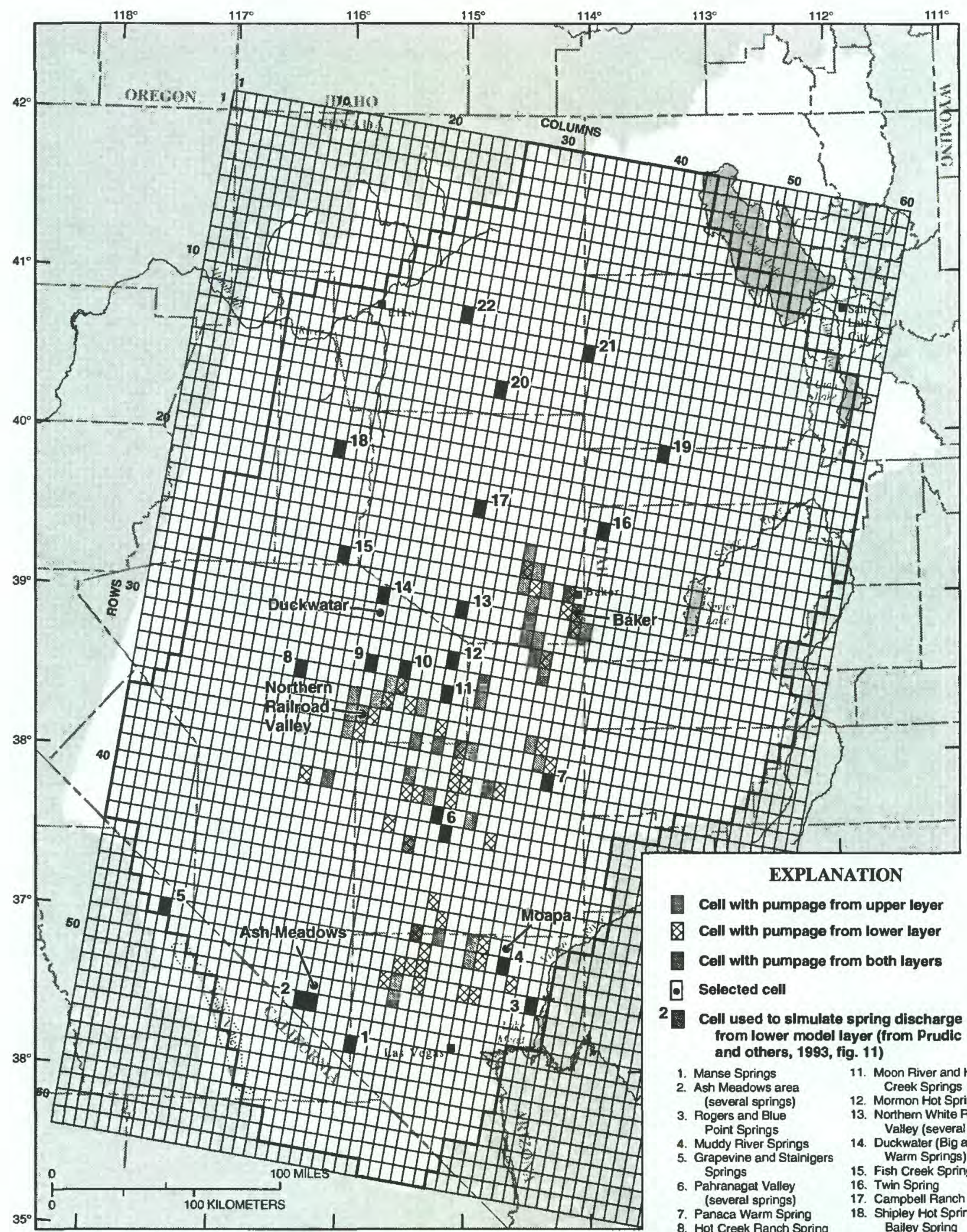

Base modified from U.S. Geological Survey digital data, 1:100,000 and 1:250,000

Albers Equal-Area Conic projection

Standard parallels $29^{\circ} 30^{\prime}$ and $45^{\circ} 30^{\prime}$, central meridian $-114^{\circ}$

2 Cell used to simulate spring discharge from lower model layer (from Prudic and others, 1993, fig. 11)

1. Manse Springs

2. Ash Meadows area

(several springs)

11. Moon River and $\mathrm{Hol}$

3. Rogers and Bine

Point Springs

4. Muddy Piver Springs

5. Grapevine and Stainigers

Springs

Creek Springs

12. Mormon Hol Spring

13. Northern White River

Valley (several springs)

14. Duckwater (Big and Little

Warm Springs)

6. Pahranagat Valley

(several springs)

7. Panaca Warm Spring

8. Hol Creek Ranch Spring

9. Lockes (several springs)

10. Blue Eagle and Tom Springs

15. Fish Creek Springs

16. Twin Spring

17. Campbell Ranch Springs

18. Shipley Hot Spring and Bailey Spring

19. Fish Springs

20 Nalson Spring

21. Blue Lake and Little Salt Springs

22. Warm Springs

Boundary of carbonate-rock province model

Figure 11. Location of spring cells, pumping cells, and selected cells in model grid. 
Figure 12 shows two hydrographs for the selected cells in the northern part of Railroad Valley (173B), one near Duckwater spring (column 21, row 29) and one near the southern part of the valley (column 21, row 35). Drawdown is not simulated at these places until after 18 years (the fourth stress period), when pumpage is assigned in Railroad Valley, then drawdowns increase steadily.

Simulated drawdowns at the selected cell near Duckwater are small, generally a few tenths of a foot in the upper layer and lower layer. The simulated draw- down at the selected cell in the southern part of the valley is more substantial, approaching $100 \mathrm{ft}$ in both the upper and lower layers. Because placement of the proposed pumping wells is primarily in the southern part of Railroad Valley, pumping will have much more effect on water levels in the southern part than in the northern part.

Figure 13 shows hydrographs for three selected cells representing areas near Ash Meadows springs, Baker, and Moapa (locations shown in fig. 11).

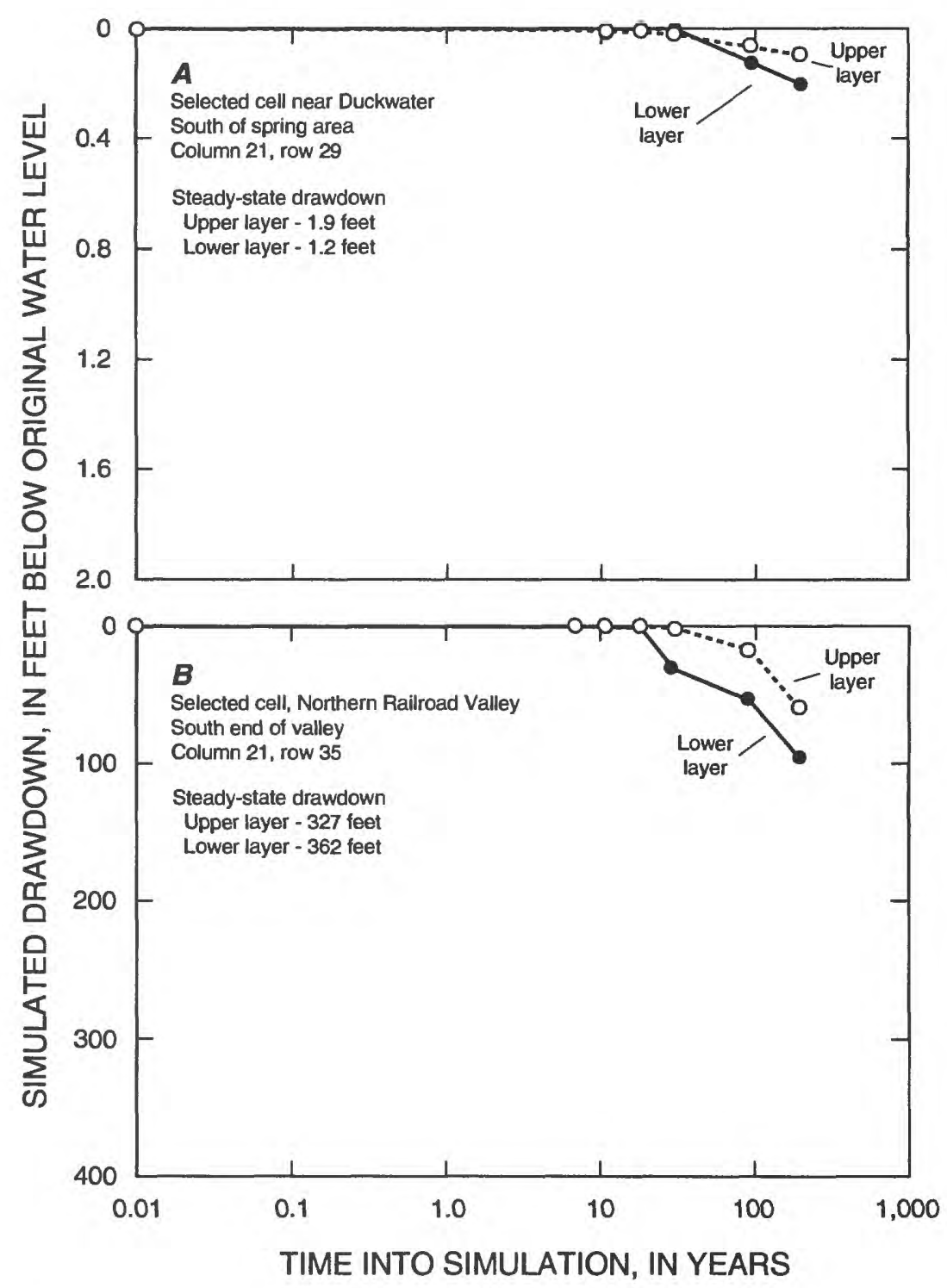

Figure 12. Hydrographs for two selected cells representing areas in northern Railroad Valley, east-central Nevada. 


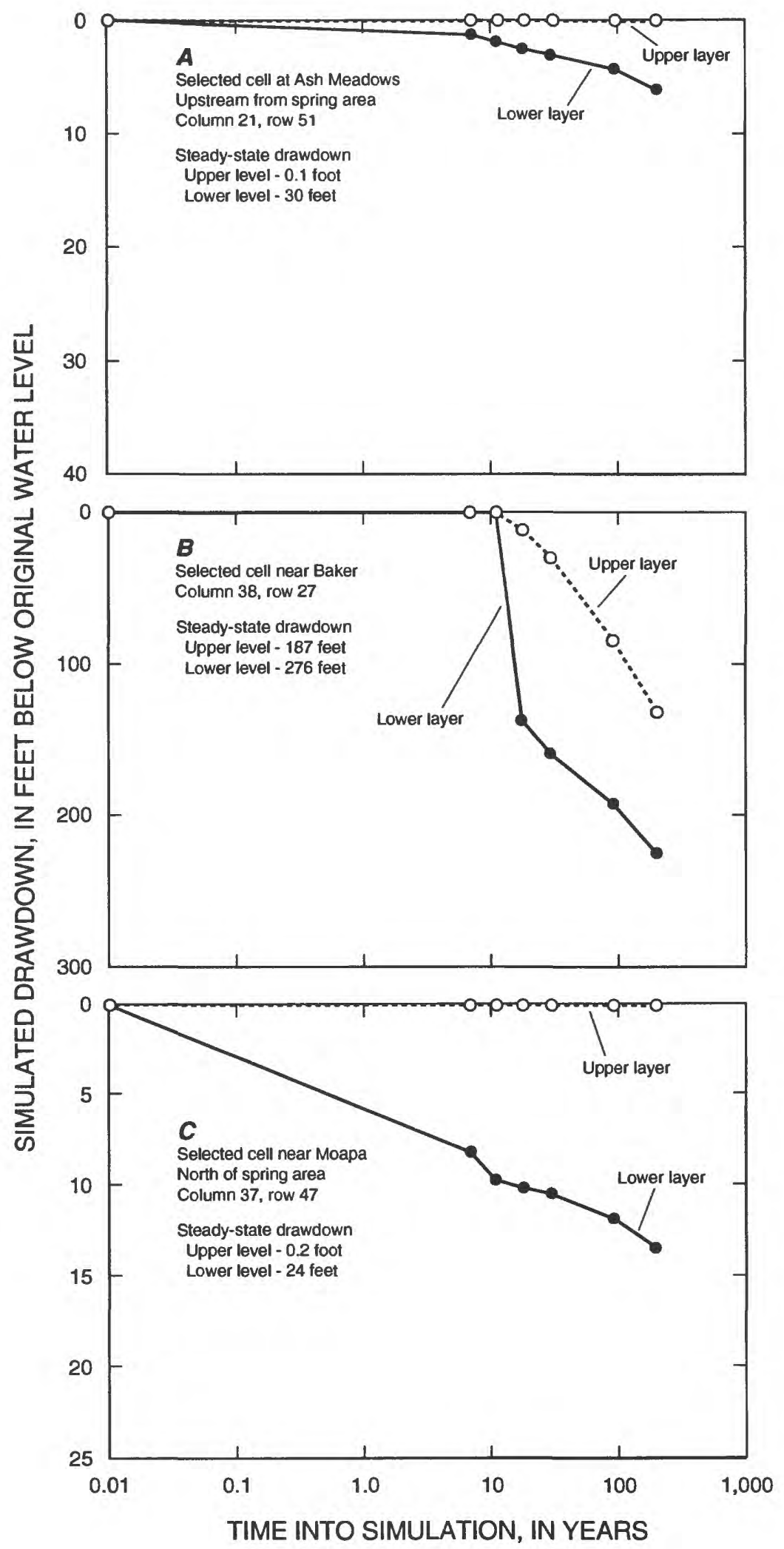

Figure 13. Hydrographs for three selected cells representing areas near Ash Meadows springs, Baker, and Moapa, southern Nevada. 
The selected cell near Ash Meadows shows small changes in the simulated water level in the lower layer soon after the simulation is started. The simulated drawdown increases after about 7 years (during stressperiod two), then increases rapidly after 100 years (during stress-period five). Equilibrium in the water level of the lower layer is not achieved even during the last stages of the model simulation. Simulated drawdowns in the lower layer near Ash Meadows springs reach a maximum of about $6 \mathrm{ft}$, whereas no decline is apparent in the upper layer. The hydrograph for the cell near Baker shows that effects from pumping begin after 10 years into the simulation, when pumping begins in Snake Valley. Simulated drawdowns increase steadily, exceeding $100 \mathrm{ft}$ in the upper layer and $200 \mathrm{ft}$ in the lower layer.

The selected cell near Moapa shows small declines in the lower layer and virtually no drawdown in the upper layer. The lower-layer drawdowns begin almost immediately, due to pumpage in the general area, and continue to increase throughout the entire 200 years of simulation. Simulated drawdowns in the lower layer at the Moapa cell reach about $13 \mathrm{ft}$ near the end of the simulation.

\section{Regional Springs}

Effects of pumping on regional springs can be attributed to many factors. One of the most important factors is the distance from the proposed pumping to the springs. Most of the proposed well sites (shown as pumping cells in fig. 11) are miles from the major regional springs in the carbonate-rock province. As the wells are pumped, the removal of water from the ground-water system can, in some places, result in a decrease in flow at the springs. These regional springs commonly support large populations of wildlife, including several threatened or endangered species and, consequently, may be of interest to the Federal Government.

As discussed by Prudic and others (1993), regional springs in the carbonate-rock province are treated as discharging from the lower layer in the model. Because of the coarseness of the model grid, these springs must occupy a cell size of 5 by $7.5 \mathrm{mi}$. Exact effects at the spring itself are difficult to predict because of this grid coarseness. The model can only show that flow at these springs might be reduced, depending on the amount and location of pumpage.
Figure 14 shows how simulated flow from several selected regional springs may be affected by the proposed pumping schedule. The Muddy River spring complex (No. 4, figs. 11 and 14) demonstrates some early effects from the simulated pumping schedule. The simulated flows decreased by almost 10 percent (about $4 \mathrm{ft}^{3} / \mathrm{s}$ ) by the end of the first phase of development and continued to decrease until much later in the simulation. After about 100 years of pumping, simulated springflow has decreased about 11 percent $\left(6 \mathrm{ft}^{3} / \mathrm{s}\right)$. This spring is affected early in the simulation because of its proximity to the areas in southern Nevada that will be pumped first.

Other springs shown in figure 11 have similar decreases. The combined flow from Hiko, Crystal, and Ash Springs (Pahranagat Valley) decreased about 14 percent $\left(5 \mathrm{ft}^{3} / \mathrm{s}\right)$ after 100 years (end of time-step five, stress-period five). Simulated discharge at the Duckwater spring area in Northern Railroad Valley is relatively unaffected by pumpage in the valley even during later time steps. Water-level declines are less than $1 \mathrm{ft}$ near the north end of Railroad Valley (fig. $8 B$ ). Springs in the central part of Northern Railroad Valley (Lockes, Blue Eagle, and Tom Springs) exhibit no decrease until pumpage from the valley is simulated during the fourth phase of the water project (after 18 years). Once pumping commences in Railroad Valley, flow from these springs decreases rapidly (fig. 14).

The spring complex at Ash Meadows (No. 2, fig. 11), shows little change in flow until about 100 years into the simulation (fig. 14), with a decrease of about 2 percent (about $0.5 \mathrm{ft}^{3} / \mathrm{s}$ ). Subsequently, flow from the springs continues to decrease throughout the simulation.

The other springs shown in figure 11 do not generally show effects of pumpage to any great degree. This is probably due to the distance between these springs and any pumping centers, or possibly the effect of intervening hydrologic boundaries. Moon River and Hot Creek Springs and Panaca Warm Spring do, however, show a decrease in springflow in the later time steps of stress-period five (greater than 100 years of model simulation). Table 3 lists the discharge from the various springs shown in figures 11 and 14 for the selected stress periods. 

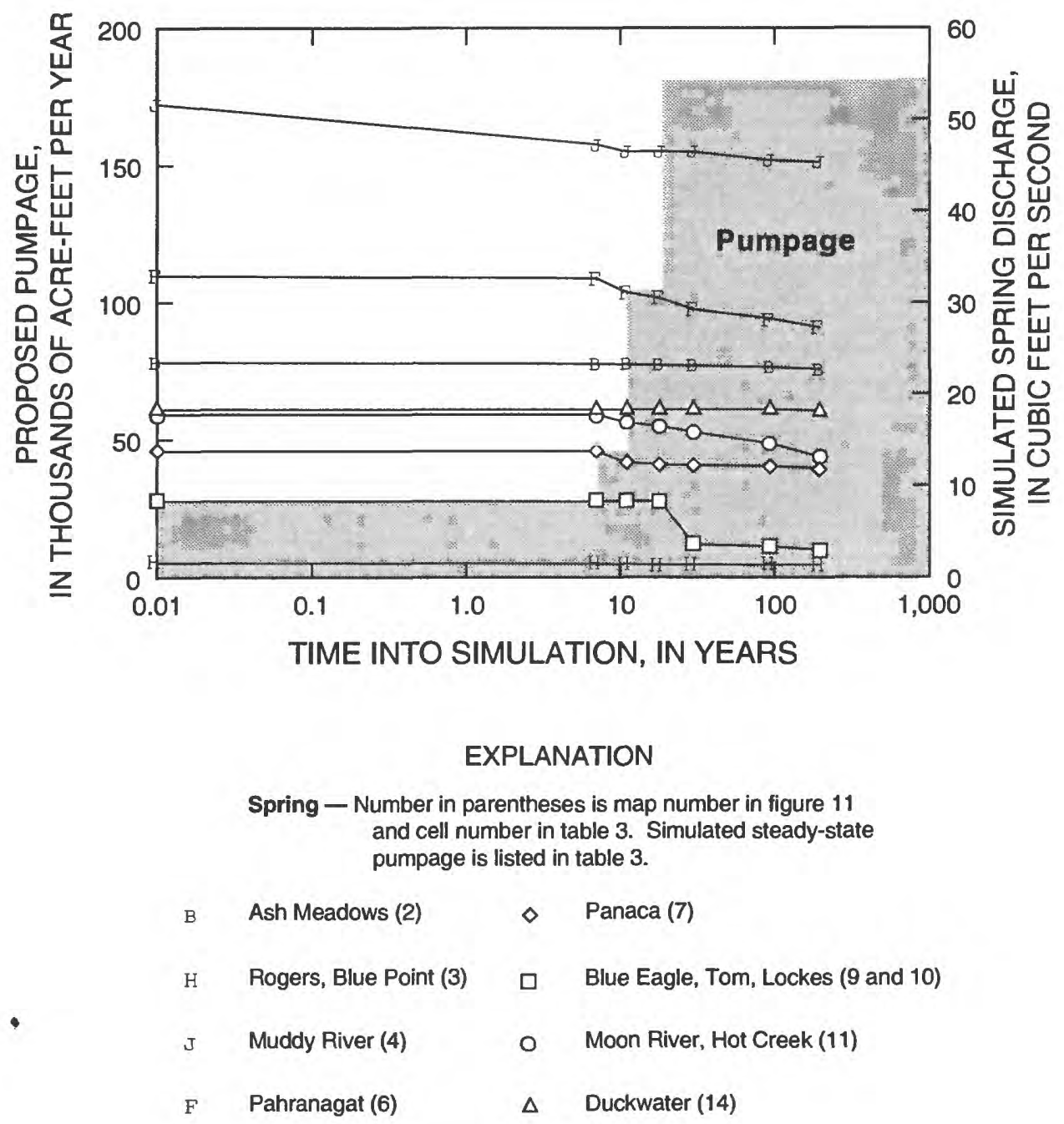

Figure 14. Changes in discharge of selected regional springs with changing pumpage, east-central and southern Nevada.

\section{Evapotranspiration}

Sustained pumpage of ground water can cause declines in water levels that may affect plants that send roots down far enough to reach the water table. These plants, known as phreatophytes, are the major source of ground-water discharge in many valleys. This use of ground water by phreatophytes is one part of the overall ground-water discharge quantity called evapotranspiration, or ET. The other component is actual evaporation, whether from a free water surface, such as standing water exposed to the atmosphere on a playa, or water beneath the ground surface but shallow enough to move upward by capillary action and evaporate. 


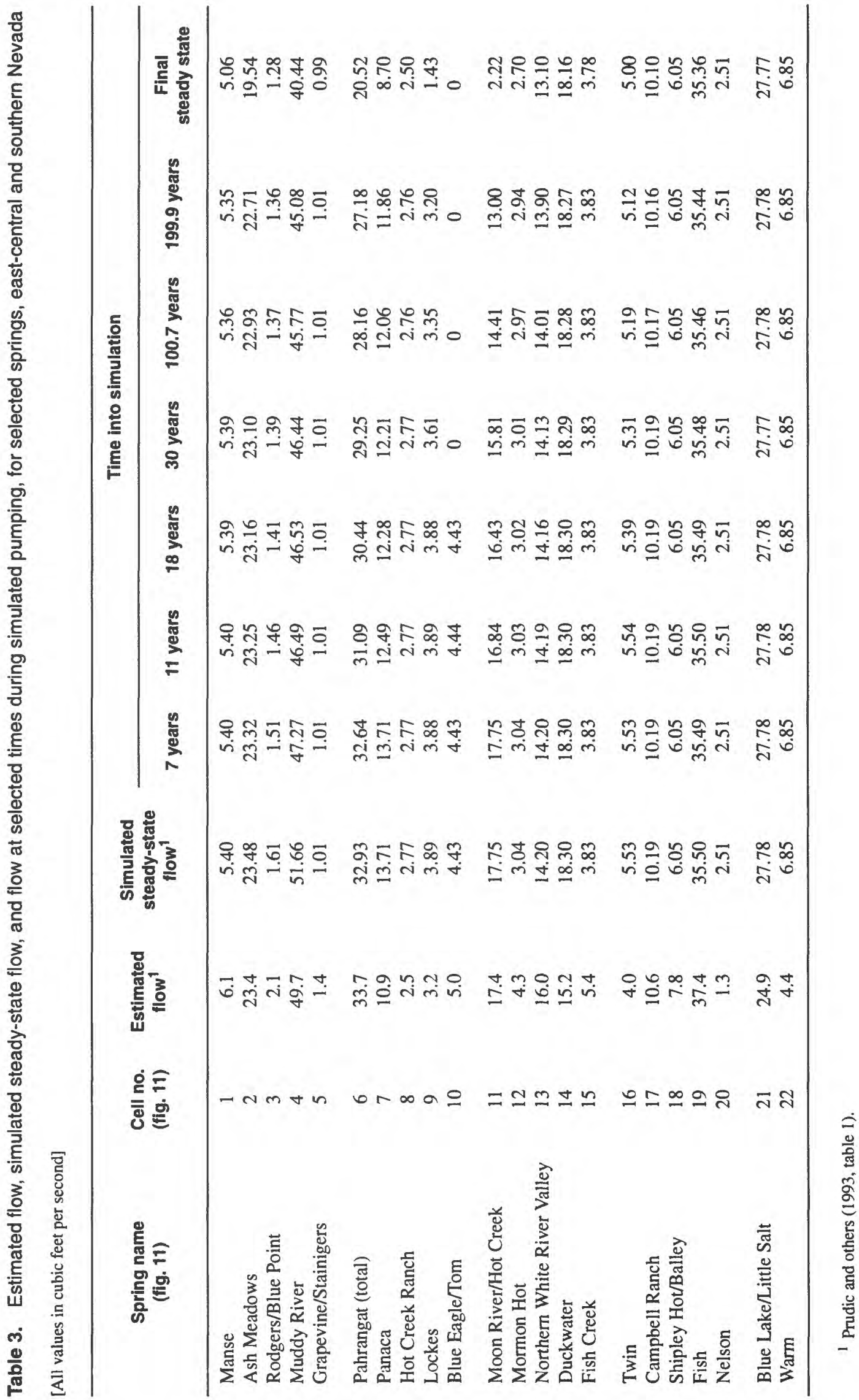


Table 4 lists ET changes for selected groups of cells during the selected time steps of the simulation. This simulated discharge is in addition to simulated spring discharge, most of which is ultimately consumed by ET. These groups of cells represent areas in several ground-water basins where phreatophytes are consuming ground water. In many valleys, this area of ET is in the center of the valley where ground water is near land surface and phreatophytes or evaporation can cause discharge from the ground-water system. Evapotranspiration can often be the major source of discharge in some of the basin-fill aquifers. This is the case in Railroad Valley where outflow from the ground-water system of the entire valley (including Duckwater and other springflow) due to ET was estimated to be 80,000 acre-ft/yr (Van Denburgh and Rush, 1974, p. 29), and is by far the largest component of discharge. Spring Valley also has a large discharge component due to ET. Rush and Kazmi (1965, table 7) estimated an ET discharge of 70,000 acre-ft/yr in the valley. Table 4 also shows that the three valleys with the largest proposed pumping (Railroad, Spring, and Snake Valleys) have the largest decrease in ET rates.

Figure 15 shows the relation between the rate of ET from these groups of cells to proposed phased pumpage in the study area. Most cells show little effect of the pumping during the early stress periods because water from storage supplies the requirements. The cells representing ET areas in virtually all the valleys, however, show some effect from the pumpage, usually starting within about 30 years from the onset of pumping.

Table 4. Simulated pumpage and evapotranspiration rates in selected areas, east-central and southern Nevada

\begin{tabular}{|c|c|c|c|c|c|c|c|c|c|c|}
\hline \multirow[b]{2}{*}{$\begin{array}{l}\text { Stress } \\
\text { period }\end{array}$} & \multirow[b]{2}{*}{$\begin{array}{l}\text { Time } \\
\text { step }\end{array}$} & \multirow[b]{2}{*}{$\begin{array}{c}\text { Years } \\
\text { into } \\
\text { simulation }\end{array}$} & \multicolumn{2}{|c|}{ Total pumpage } & \multicolumn{6}{|c|}{ Evapotranspiration (cubic feet per second) } \\
\hline & & & $\begin{array}{l}\text { Acre-feet } \\
\text { per year }\end{array}$ & $\begin{array}{l}\text { Cubic } \\
\text { feet per } \\
\text { Second }\end{array}$ & $\begin{array}{l}\text { Death } \\
\text { Valley }\end{array}$ & $\begin{array}{c}\text { Amargosa } \\
\text { area }\end{array}$ & $\begin{array}{l}\text { Las } \\
\text { Vegas } \\
\text { Valley }\end{array}$ & $\begin{array}{l}\text { Lower } \\
\text { White } \\
\text { River } \\
\text { Valley }\end{array}$ & $\begin{array}{c}\text { Pahrangat } \\
\text { Valley }\end{array}$ & $\begin{array}{c}\text { Garden, } \\
\text { Coal } \\
\text { Valleys }\end{array}$ \\
\hline \multicolumn{2}{|c|}{ Steady-state model } & 0 & 0 & 0 & 6.66 & 11.98 & 34.26 & 18.28 & 13.49 & 0.00 \\
\hline 1 & 2 & 7 & 24,500 & 32.75 & 6.64 & 11.98 & 34.23 & 18.25 & 13.41 & .00 \\
\hline 2 & 2 & 11 & 47,000 & 62.83 & 6.66 & 11.98 & 34.20 & 18.23 & 13.33 & .00 \\
\hline 3 & 2 & 18 & 118,000 & 157.75 & 6.66 & 11.97 & 34.17 & 18.19 & 13.18 & .00 \\
\hline 4 & 3 & 30 & 180,800 & 241.71 & 6.67 & 11.97 & 34.16 & 18.13 & 12.95 & .00 \\
\hline 5 & 5 & 100 & 180,800 & 241.71 & 6.66 & 11.91 & 34.11 & 17.79 & 12.10 & .00 \\
\hline 5 & 10 & 200 & 180,800 & 241.71 & 6.66 & 11.84 & 34.02 & 17.40 & 11.25 & .00 \\
\hline \multicolumn{3}{|c|}{ Final steady-state } & 180,800 & 241.71 & 6.58 & 10.18 & 32.45 & 14.70 & 6.04 & .00 \\
\hline
\end{tabular}

\begin{tabular}{|c|c|c|c|c|c|c|c|c|c|c|}
\hline \multirow[b]{2}{*}{$\begin{array}{l}\text { Stress } \\
\text { period }\end{array}$} & \multirow[b]{2}{*}{$\begin{array}{l}\text { Time } \\
\text { step }\end{array}$} & \multirow{2}{*}{$\begin{array}{c}\text { Years } \\
\text { into } \\
\text { simulation }\end{array}$} & \multicolumn{2}{|c|}{ Total pumpage } & \multicolumn{6}{|c|}{ Evapotranspiration (cubic feet per second) } \\
\hline & & & $\begin{array}{l}\text { Acre-feet } \\
\text { per year }\end{array}$ & $\begin{array}{l}\text { Cubic } \\
\text { feet per } \\
\text { Second }\end{array}$ & $\begin{array}{c}\text { Southern } \\
\text { Railroad } \\
\text { Valley }\end{array}$ & $\begin{array}{c}\text { Northern } \\
\text { Railroad } \\
\text { Valley }\end{array}$ & $\begin{array}{l}\text { White } \\
\text { River } \\
\text { Valley }\end{array}$ & $\begin{array}{l}\text { Spring } \\
\text { Valley }\end{array}$ & $\begin{array}{l}\text { Lake } \\
\text { Valley }\end{array}$ & $\begin{array}{l}\text { Snake } \\
\text { Valley }\end{array}$ \\
\hline \multicolumn{2}{|c|}{ Steady-state model } & 0 & 0 & 0 & 2.99 & 89.38 & 19.34 & 102.97 & 10.87 & 93.51 \\
\hline 1 & 2 & 7 & 24,500 & 32.75 & 2.99 & 89.38 & 19.36 & 102.97 & 10.87 & 93.52 \\
\hline 2 & 2 & 11 & 47,000 & 62.83 & 3.00 & 89.40 & 19.36 & 102.99 & 10.89 & 93.53 \\
\hline 3 & 2 & 18 & 118,000 & 157.75 & 2.99 & 89.38 & 19.34 & 78.41 & 10.72 & 87.19 \\
\hline 4 & 3 & 30 & 180,800 & 241.71 & 2.96 & 65.71 & 19.33 & 70.37 & 10.37 & 84.27 \\
\hline 5 & 5 & 100 & 180,800 & 241.71 & 2.59 & 56.76 & 19.25 & 57.76 & 8.68 & 75.28 \\
\hline 5 & 10 & 200 & 180,800 & 241.71 & 2.16 & 52.01 & 19.16 & 53.04 & 7.46 & 68.79 \\
\hline \multicolumn{3}{|c|}{ Final steady-state } & 180,800 & 241.71 & .19 & 43.38 & 18.27 & 46.94 & 3.46 & 56.55 \\
\hline
\end{tabular}




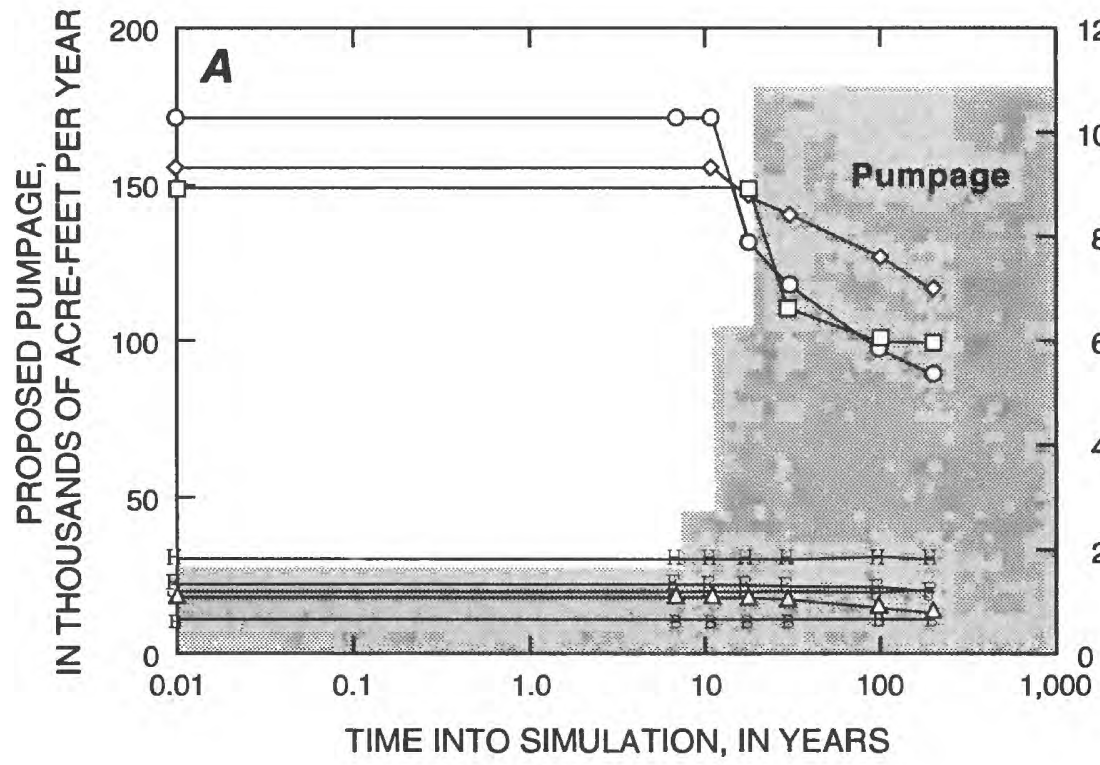
120
点
100
응
造总
80 山
욤
崖
60
존
क्ञ
更
40
紊㤩
Hydrographic areas for which changes in simuiated evapotranspiration (ET) are shown - Map numbers (figure 15B) are indicated in parentheses. Simulated new steady-state evapotranspiration rates are listed in table 4
J Amargosa Desert (1)
B Death Valley (2)
$\Delta \quad$ Lake Valley (3)
F Pahranagat Valley (4)
ㅁ Railroad Valley (5)
$\diamond \quad$ Snake Valley (6)
- Spring Valley (7)
H White River Valley (8)

\section{EXPLANATION}

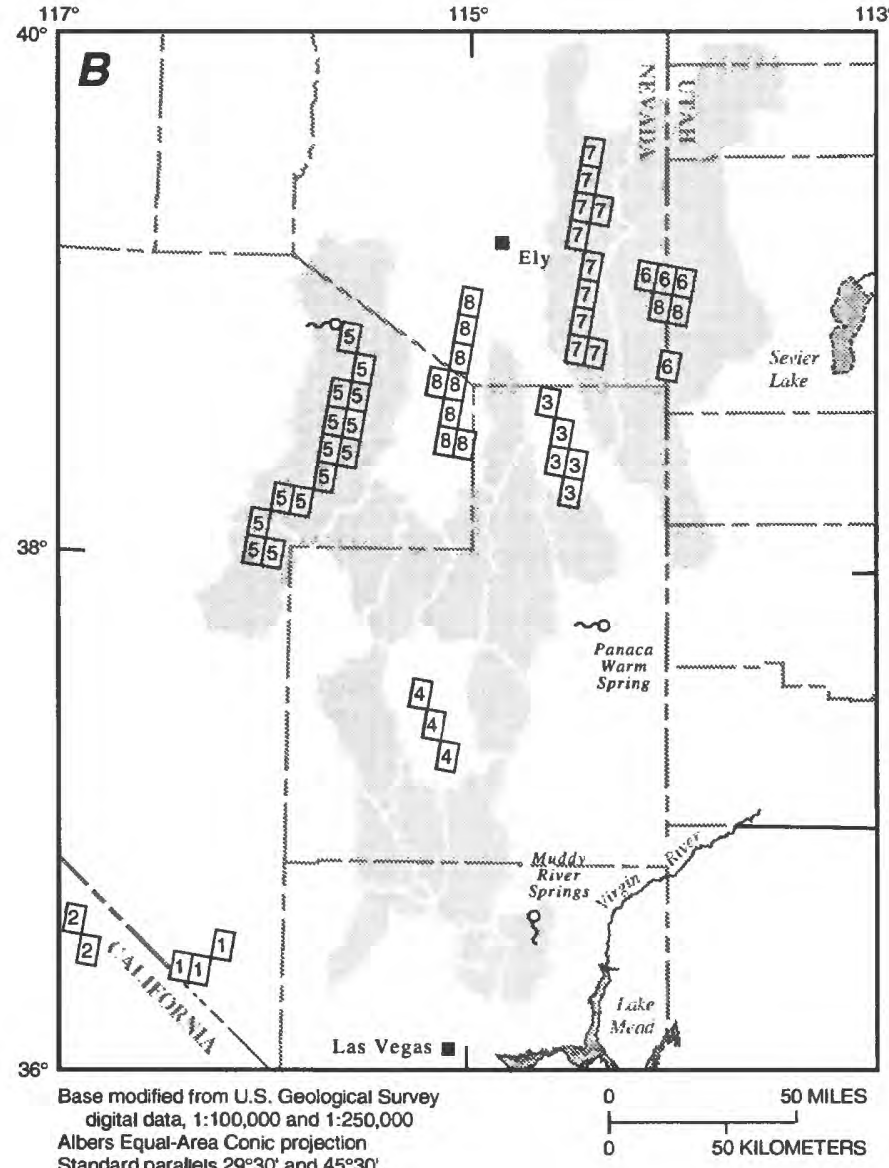

EXPLANATION

Hydrographic area in which pumping is proposed

6. Evapotranspiration cells - Map number coinciding with fist of hydrographic areas (figure 15A) is indicated

Figure 15. Changes in simulated evapotranspiration at cells in selected basins with changes in proposed pumpage. 


\section{Sensitivity of Model Results to Storage Values}

To test the sensitivity of the model to input values, several additional simulations were made by varying the values of aquifer storage. Transmissivity values from the original model (Prudic and others, 1993) were not tested during this study. Previous sensitivity analyses were deemed sufficient, and although transmissivity values may be more variable than storage values in a given geologic unit, storage values may be more responsible for long-term effects in the simulation.

The storage values for both the basin-fill and carbonate aquifers are not well known, and may cause the results of the model to vary significantly. Changing the storage values of the upper layer by a range of \pm 50 percent, and changing the storage values of the lower layer to the two endpoints of $7.6 \times 10^{-5}$ and $1.2 \times 10^{-3}$, were assumed to give a reasonable test of how results might change. The model was rerun using these adjusted storage values, and figures 16 through 18 show how various key budget components change throughout the simulation, compared to the results obtained using the original storage values.

Figure 16 shows how regional spring discharge varies in response to changing storage-coefficient estimates. In general, storage-coefficient values for the upper layer have little effect on simulated spring discharge. At any given time, the smaller storage coefficients cause less discharge from the drains, whereas larger storage values for the upper layer allow for more
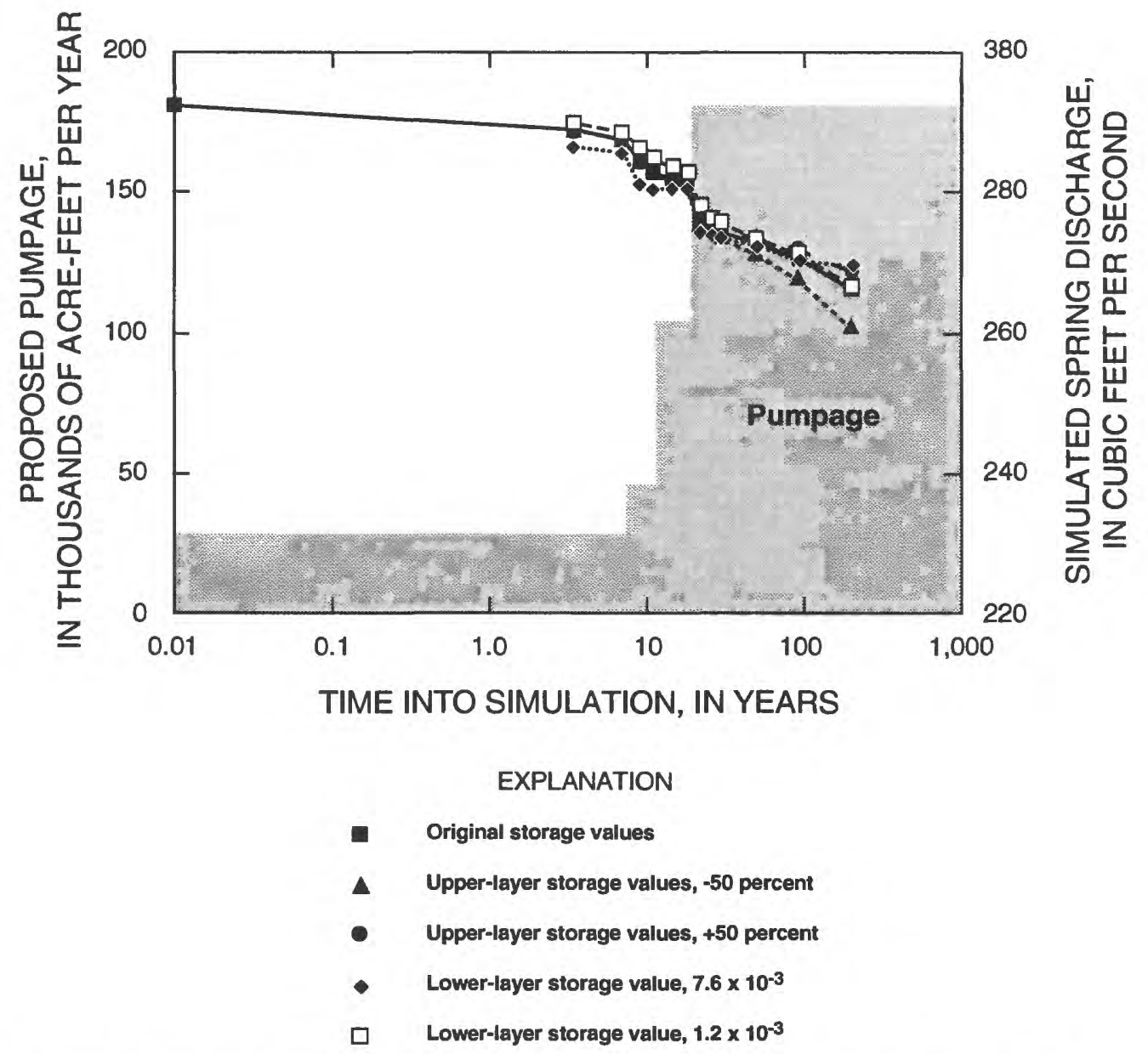

Figure 16. Changes in total model-simulated spring discharge with selected storage values and changing pumpage, east-central and southern Nevada. (All simulated spring discharge totals for the several values converged to a simulated total spring discharge of 234 cubic feet per second in the steady-state simulation.) 
discharge. Adjusting the lower-layer storage coefficient has virtually no effect on the simulated spring discharge of the model.

Figure 17 shows how simulated evapotranspiration changes in response to varying storage coefficients. During the first 10 years of the simulation, simulated ET differs little for any of the storagecoefficient values shown in figure 17. However, as the simulation continues and pumpage increases, simulated ET begins to decrease as it is captured by pumping. The simulated rate of decrease in ET varies with the values assigned to the upper layer storage coefficient. Generally, decreasing the storage coefficient caused ET to be captured more quickly.
The model is relatively insensitive to changes in the lower layer, which has a storage coefficient typical of a confined aquifer. The amount of evapotranspiration ultimately captured by pumping is the same (about $190 \mathrm{ft}^{3} / \mathrm{s}$ ), so varying the storage coefficient has no effect on the ultimate reduction of evapotranspiration. Adjusting the lower-layer storage coefficient has virtually no effect on the simulated ET discharge of the model.

After 100 years, the simulated change in ET ranged from about 48 percent of the total change in ET (with the storage coefficients in the upper layer increased by 50 percent) to about 62 percent of the total change in ET (with the storage coefficients in the upper layer decreased by 50 percent).
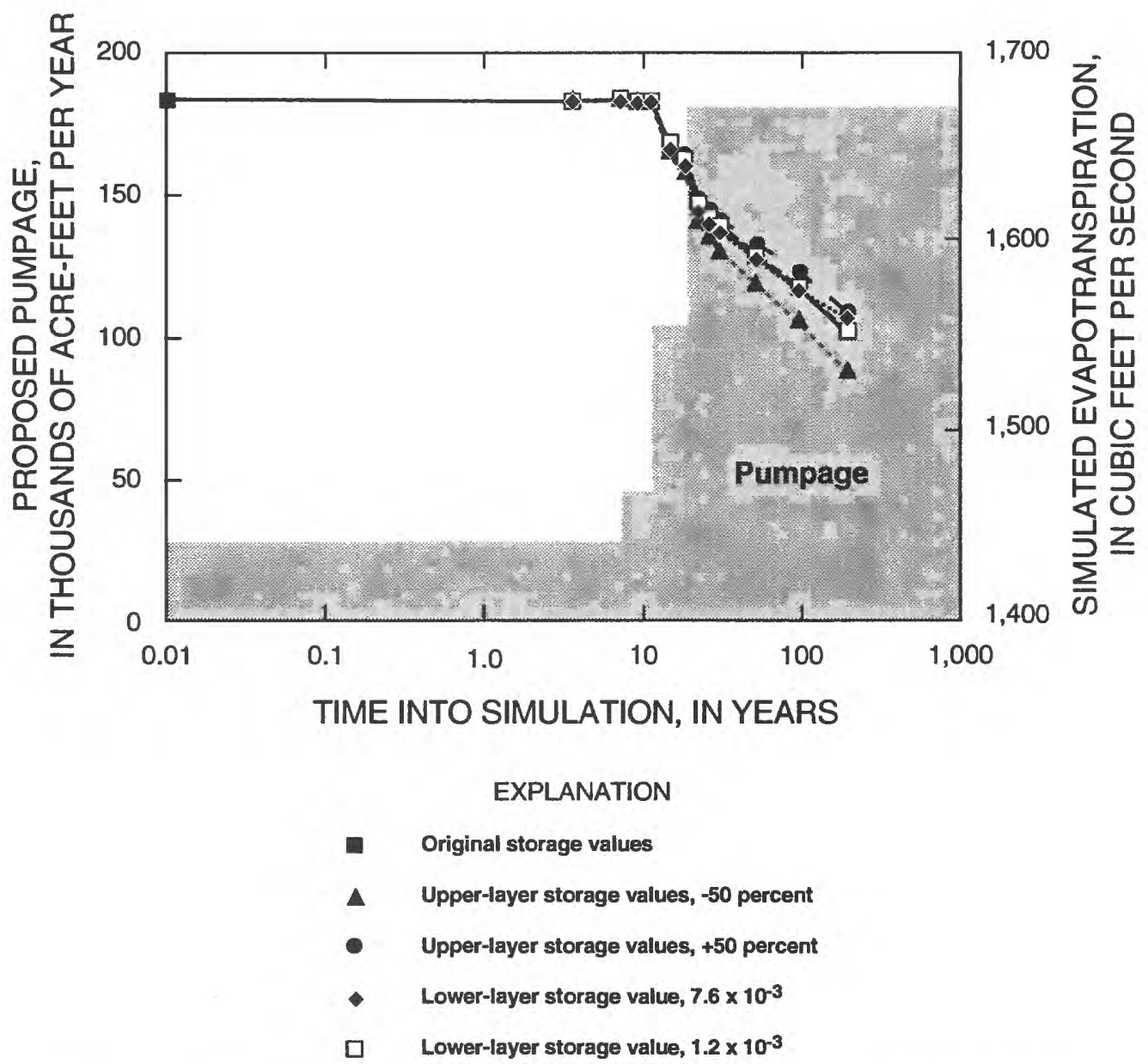

Figure 17. Changes in total model-simulated evapotranspiration with selected storage values and changing pumpage, east-central and southern Nevada. (All total model-simulated evapotranspiration for the several storage values converged to 1,484 cubic feet per second in the steady-state simulation.) 
Figure 18 shows how varying aquifer storage coefficients affect the amount of ground water coming out of storage. The graph demonstrates that the model is somewhat insensitive to varying the storage coefficients, but is extremely sensitive to increasing pumping rates. As the overall rates are increased with time, more water is withdrawn from storage to satisfy the demand. As the time steps progress within each stress period, an equilibrium is reached or a decline takes place as water is drawn from other sources to feed the pumpage.

Figures 19-23 are hydrographs from the selected cells described previously that show the effect of changing storage values. Figure 11 shows the locations of these cells in relation to the proposed pumping schedule of LVVWD. Figure 19 contains a hydrograph for each layer of the selected cell near Ash Meadows and shows virtually no change in the simulated drawdown in either layer due to storage- coefficient variations. The upper layer shows a difference of less than $0.01 \mathrm{ft}$ after about 100 years of simulation. The lower layer shows a difference of about $3 \mathrm{ft}$ of simulated drawdown after the same period.

Figure 20 shows simulated drawdowns for both layers at the selected cell near Baker. The hydrograph for the upper layer shows considerable variation after 100 years into the simulation, with about $90 \mathrm{ft}$ of difference in water levels computed using the two storagecoefficient end points. The difference in simulated drawdowns in the lower layer is less, with about $40 \mathrm{ft}$ of difference after the same 100 years of simulation.

Figure 21 shows the simulated drawdowns at the selected cell near Duckwater in Northern Railroad Valley. Both layers demonstrate an insensitivity to storage-coefficient changes by differing less than $0.2 \mathrm{ft}$ after about 100 years of simulated pumping.
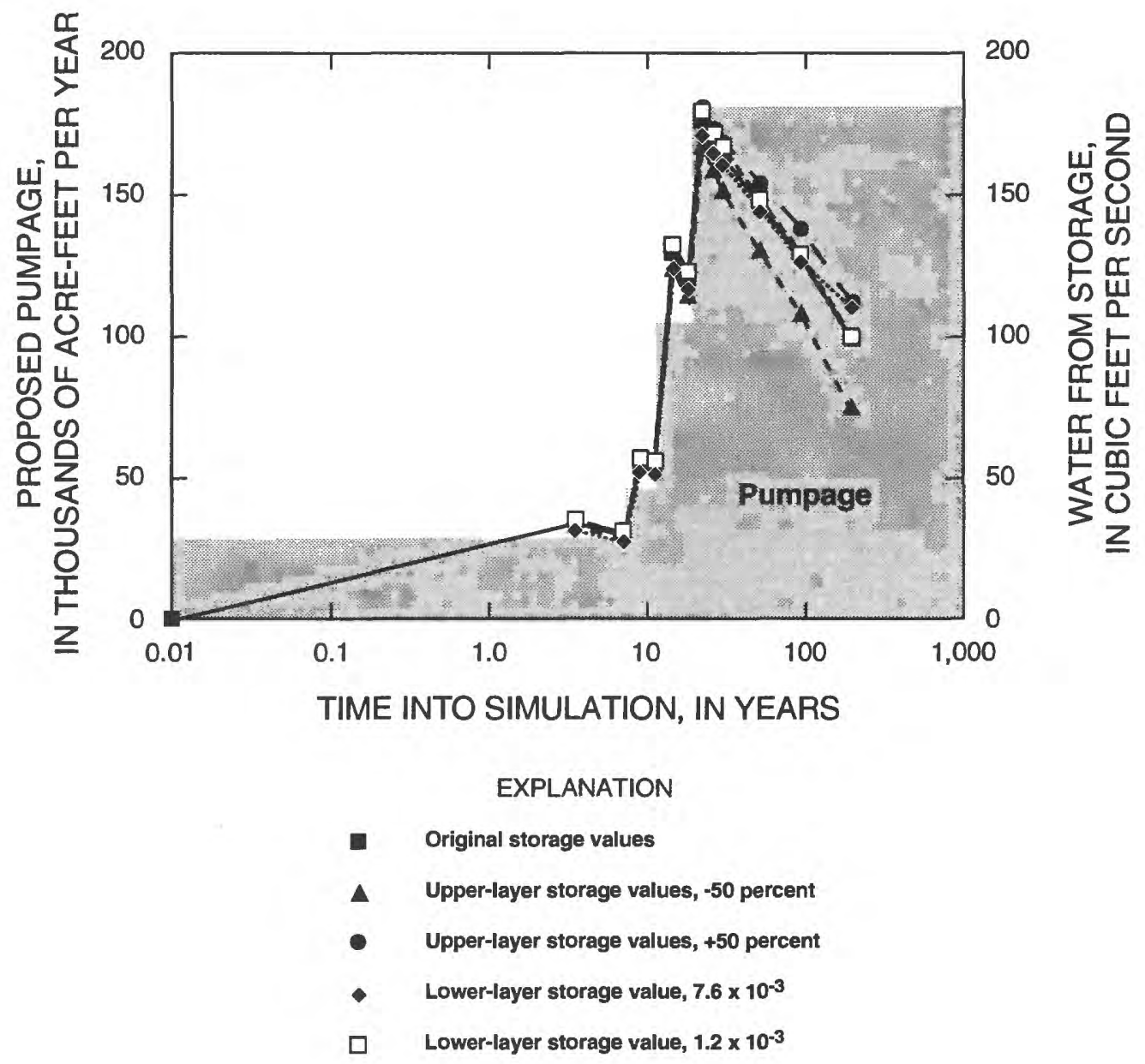

Figure 18. Changes in total model-simulated water removed from storage with selected storage values and changing pumpage, east-central and southern Nevada. 

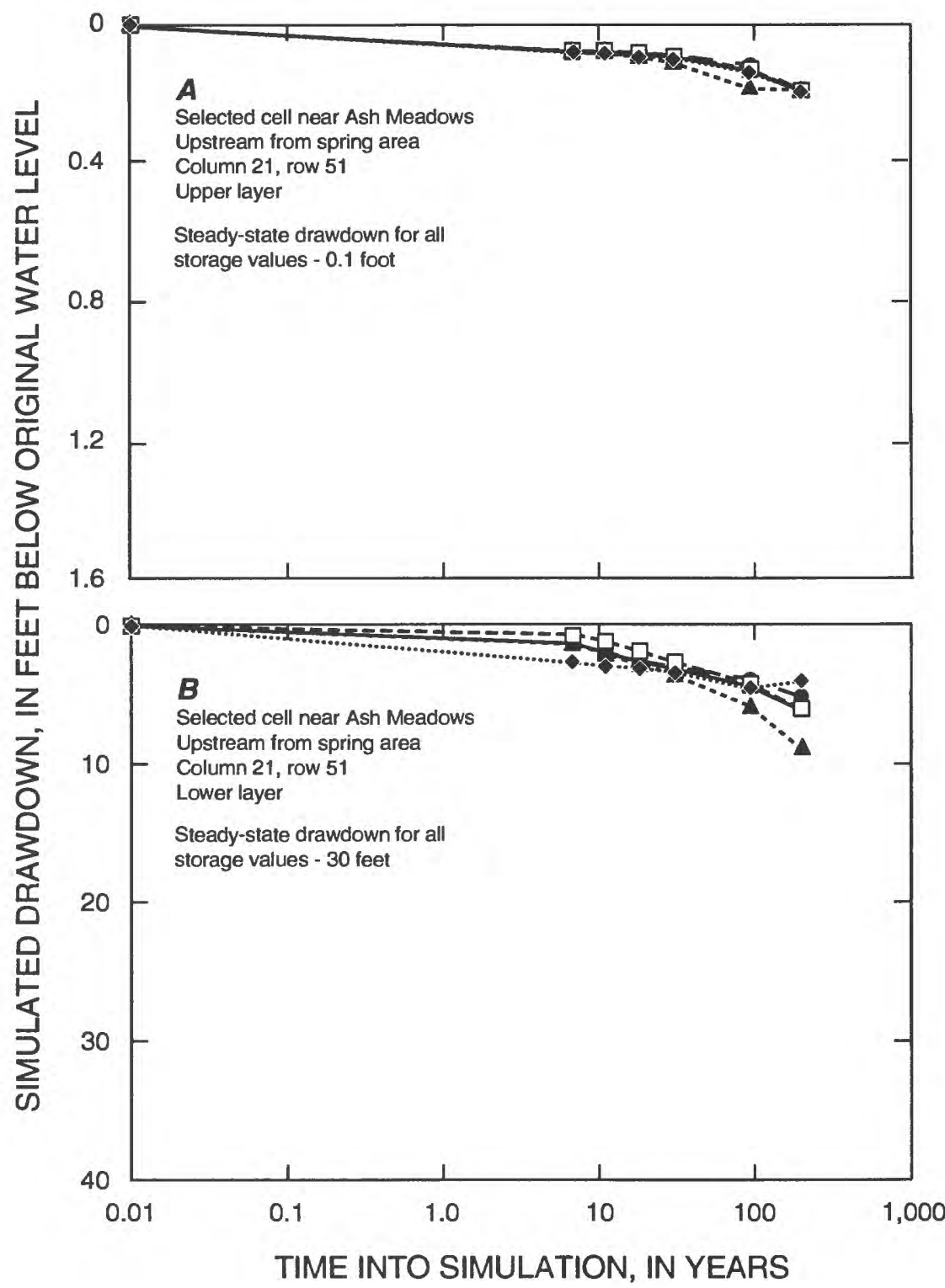

EXPLANATION

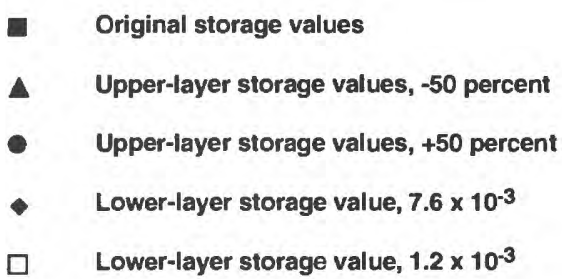

Figure 19. Hydrographs of simulated water-level drawdowns associated with selected storage values for selected cell representing an area in Ash Meadows, southern Nevada. $A$, upper layer. $B$, lower layer. 

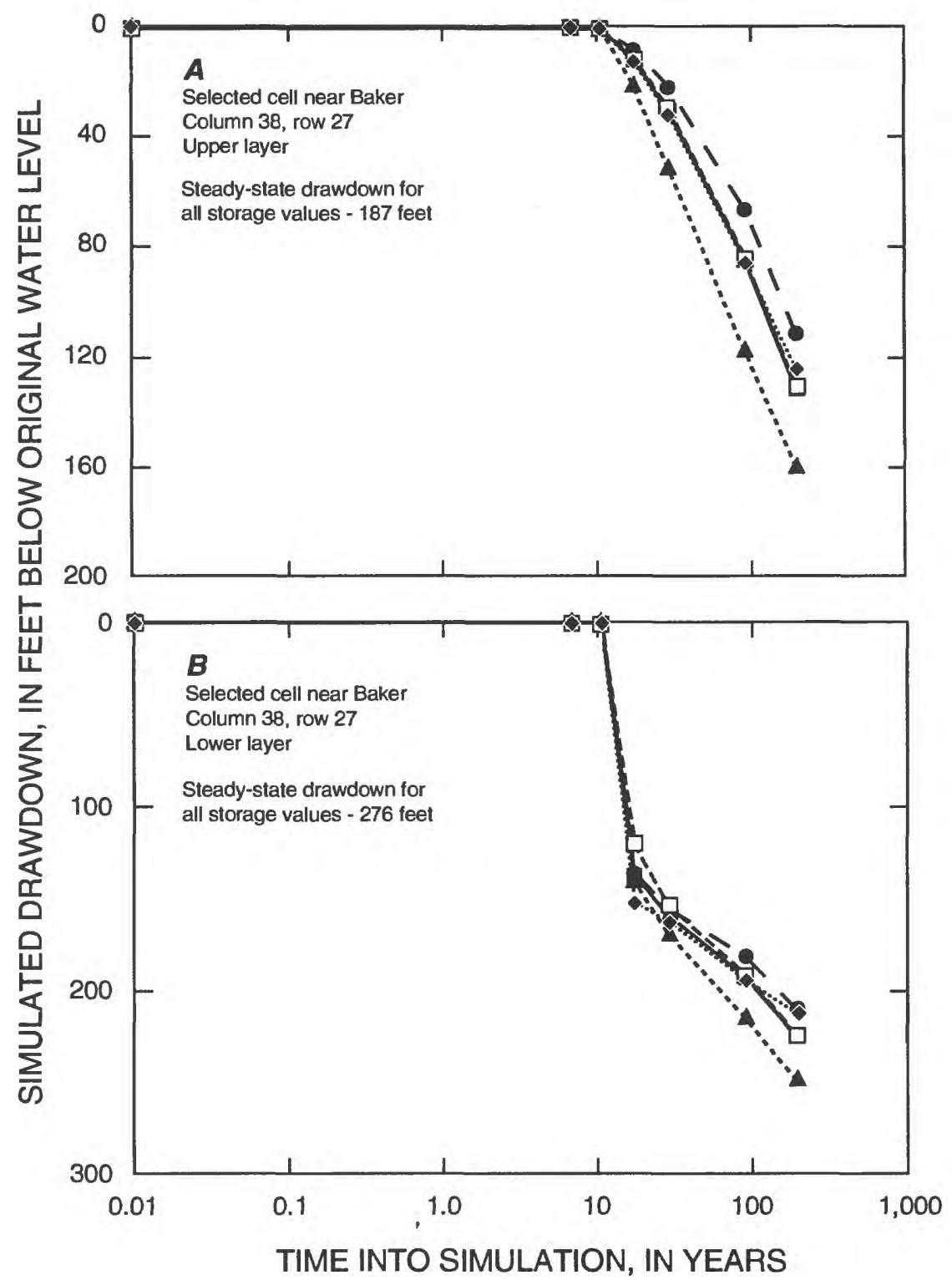

INT SIMULATION,

EXPLANATION

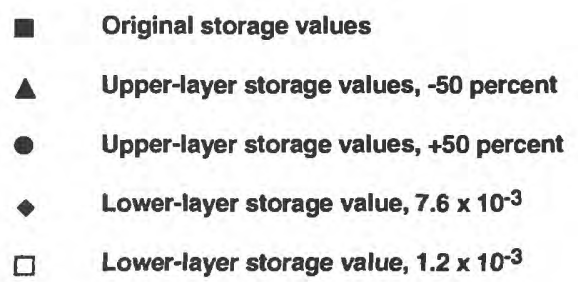

Figure 20. Hydrographs of simulated water-level drawdowns associated with selected storage values for selected cell representing an area at Baker, eastcentral Nevada. $A$, upper layer. $B$, lower layer. 


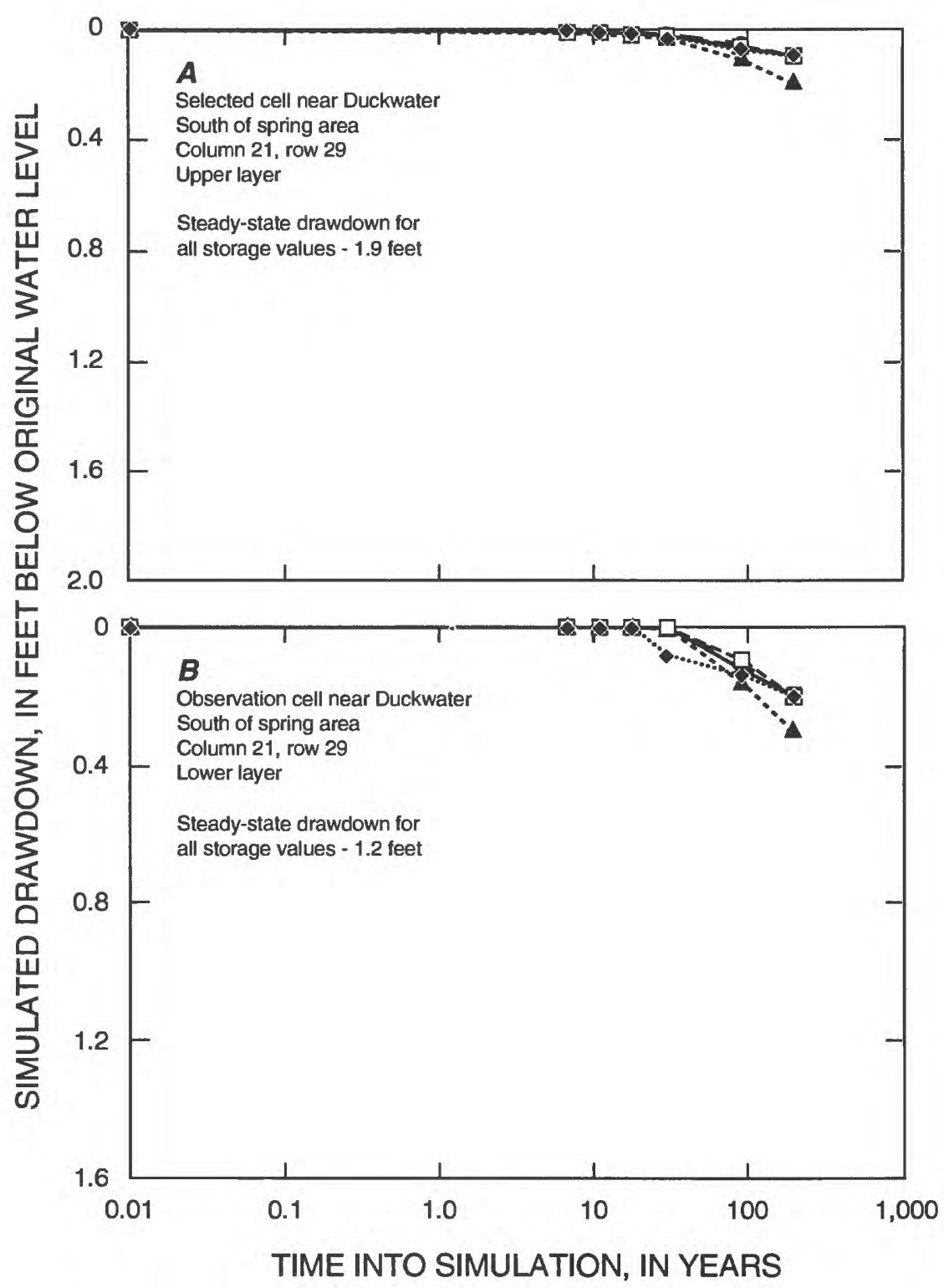

\section{EXPLANATION}

- Original storage values

U Upper-layer storage values, -50 percent

- Upper-layer storage values, +50 percent

- Lower-layer storage value, $7.6 \times 10^{-3}$

$\square \quad$ Lower-layer storage value, $1.2 \times 10^{-3}$

Figure 21. Hydrographs of simulated water-level drawdowns associated with selected storage values for selected cell representing an area at Duckwater, east-central Nevada. $A$, upper layer. $B$, lower layer. 
Figure 22 shows the simulated drawdowns at the selected cell in Northern Railroad Valley in both layers. The upper layer demonstrates a difference in drawdowns of about $40 \mathrm{ft}$ after about 100 years into the simulation. The lower layer shows a difference of about $50 \mathrm{ft}$ after the same time period.

Figure 23 shows the simulated drawdowns at the selected cell near Moapa for both layers. The upper layer shows a difference of about $0.02 \mathrm{ft}$ in the simulated drawdowns and the lower layer shows about a 2-ft difference, after about 100 years into the simulation.

Overall, the model appears to be relatively insensitive to variations in aquifer storage coefficients. Changes in these values elicit only minor changes in evapotranspiration, spring discharge, movement of ground water out of storage, and variations in simulated drawdowns. Changes in pumping-location and rate-have a greater influence on model results.

\section{Ultimate Source of Pumped Water}

The simulation of pumping ground water in east-central and southern Nevada illustrates several concepts discussed by Theis (1940). The ultimate source of pumped ground water in an aquifer system is an increase in recharge, a decrease of natural discharge, or removal of ground water from storage. As was stated succinctly by Theis (p. 280), "All water discharged by wells is balanced by a loss of water somewhere."

The boundaries for this simulation do not allow additional water to be made available to the groundwater system of the Great Basin; pumpage will not increase precipitation and, hence, recharge. If wells were placed near some of the bounding surface-water bodies, some additional water would recharge the local ground water to make up any deficit caused by pumping. But throughout the study area, additional water from these sources is not available.

The previous discussion of how pumping in the study area affects ET and spring discharge suggests that much of the ground water pumped would be derived from these sources. Since ET is dependent on shallow water levels to support vegetation, once water levels decline sufficiently, ET would cease. Simulated spring discharge is also affected by the proposed pumping in the sense that ground-water flow to the spring is intercepted by the expanded cones of depression of the wells.

The last source of water available to the proposed pumping is from ground water in storage. Figure 24 illustrates the change in various ground-water model budget components as the simulation progresses. Also shown is a series of figures illustrating the source of water pumped in the simulation. Early in the simulation, the major source of pumped water is from groundwater storage ( 83 percent at 9 years into the simulation). As the simulation progresses, less and less water is removed from storage and the remainder of the pumped water comes from reduction in ET and spring discharge. The final stage of this progression is the steady-state simulation, where none of the pumped water is from storage, 77 percent is from what had been used by ET, and 23 percent is from reduction of springflow. This represents a simulated equilibrium within the ground-water system.

\section{Limitations and Uses of the Model}

Simulations of the proposed pumpage show that many aspects of the ground-water systems in the Great Basin may be affected. The simulations were based on a computer model of regional ground-water flow that greatly simplifies the complex distribution of geology and, consequently, the hydraulic properties of many of the rocks in the Great Basin. As the authors of the original model state, "Simulation results are based on assuming recharge to the province is known with the distribution of transmissivities simulated to match the general distribution of water levels and estimates of discharge. However, water levels in consolidated rocks are generally unknown and estimates of recharge and discharge are known only approximately" (Prudic and others, 1993, p. 91).

The adequacy of the model in simulating the effects of the proposed pumping will remain untested until actual pumping stresses have been in place long enough to cause measurable effects within the system. This would allow for calibration of transient simulations that was not possible with the previous model. 


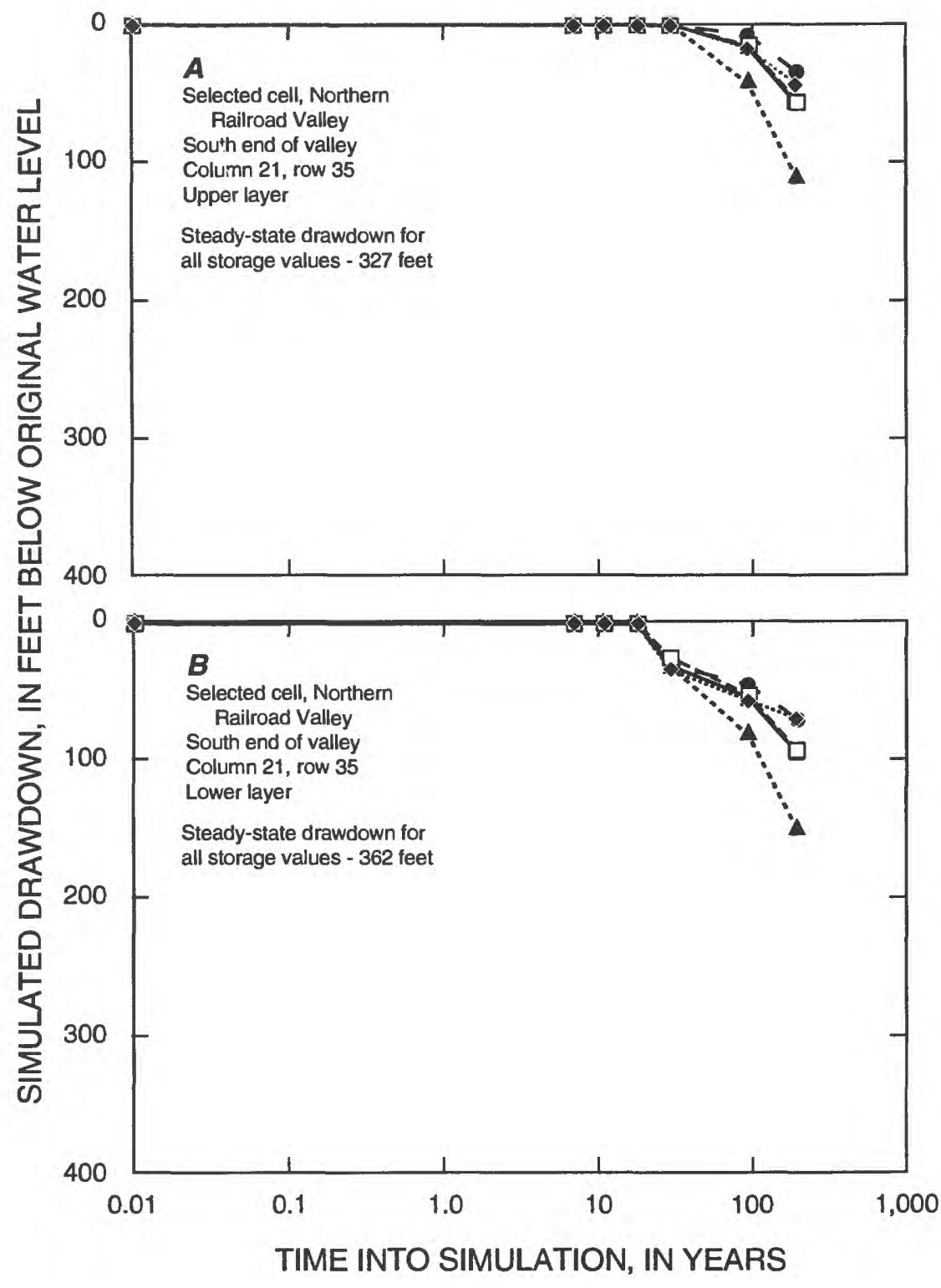

\section{EXPLANATION}

- Original storage values

U Upper-layer storage values, -50 percent

- Upper-layer storage values, +50 percent

- Lower-layer storage value, $7.6 \times 10^{-3}$

$\square \quad$ Lower-layer storage value, $1.2 \times 10^{-3}$

Figure 22. Hydrographs of simulated water-level drawdowns associated with selected storage values for selected cell representing an area in northern Railroad Valley, east-central Nevada. A, upper layer. B, lower layer. 

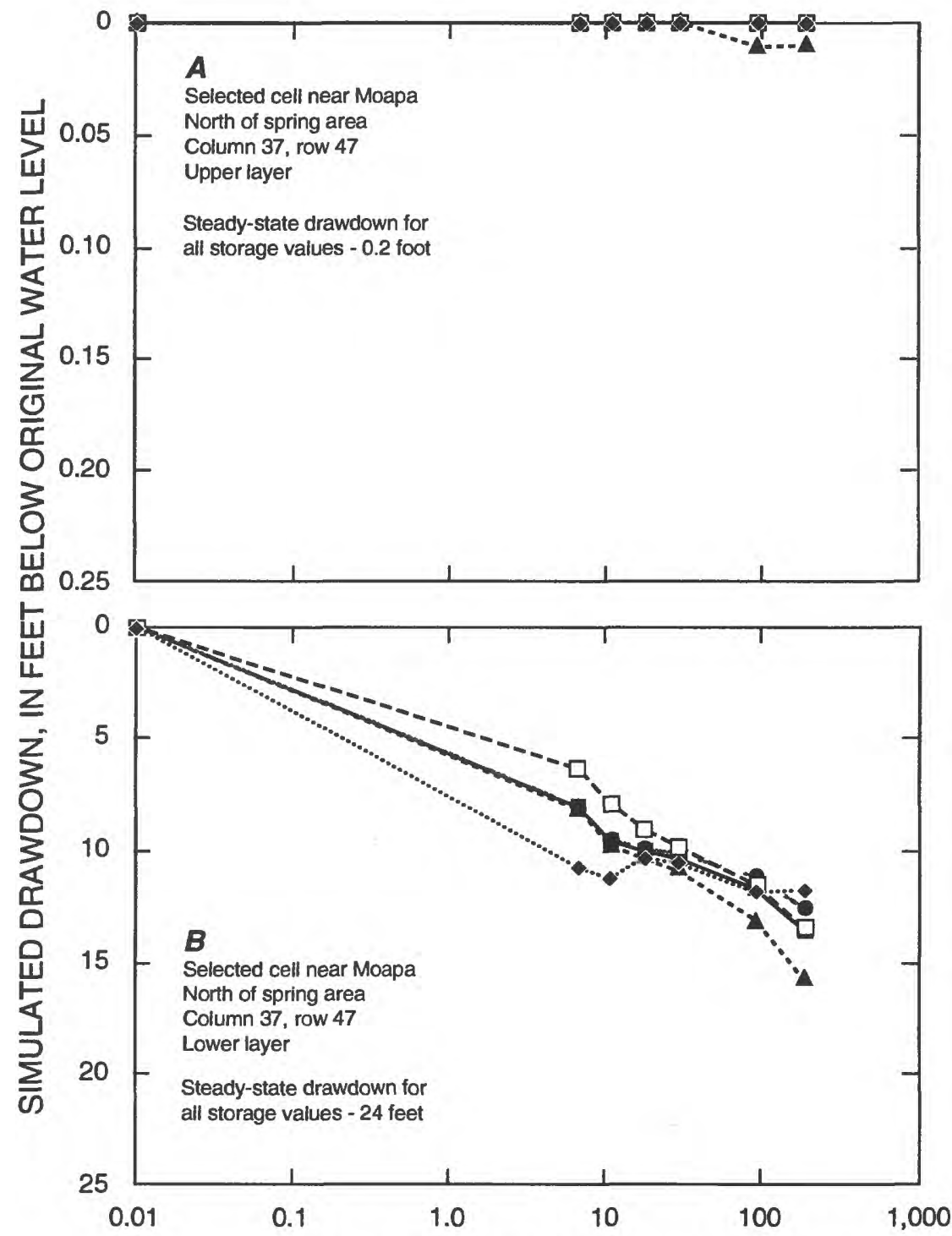

TIME INTO SIMULATION, IN YEARS

\section{EXPLANATION}

- Original storage values

U Upper-layer storage values, -50 percent

Upper-layer storage values, +50 percent

- Lower-layer storage value, $7.6 \times 10^{-3}$

$\square \quad$ Lower-layer storage value, $1.2 \times 10^{-3}$

Figure 23. Hydrographs of simulated water-level drawdowns associated with selected storage values for selected cell representing an area at Moapa, southern Nevada. $A$, upper layer. $B$, lower layer. 

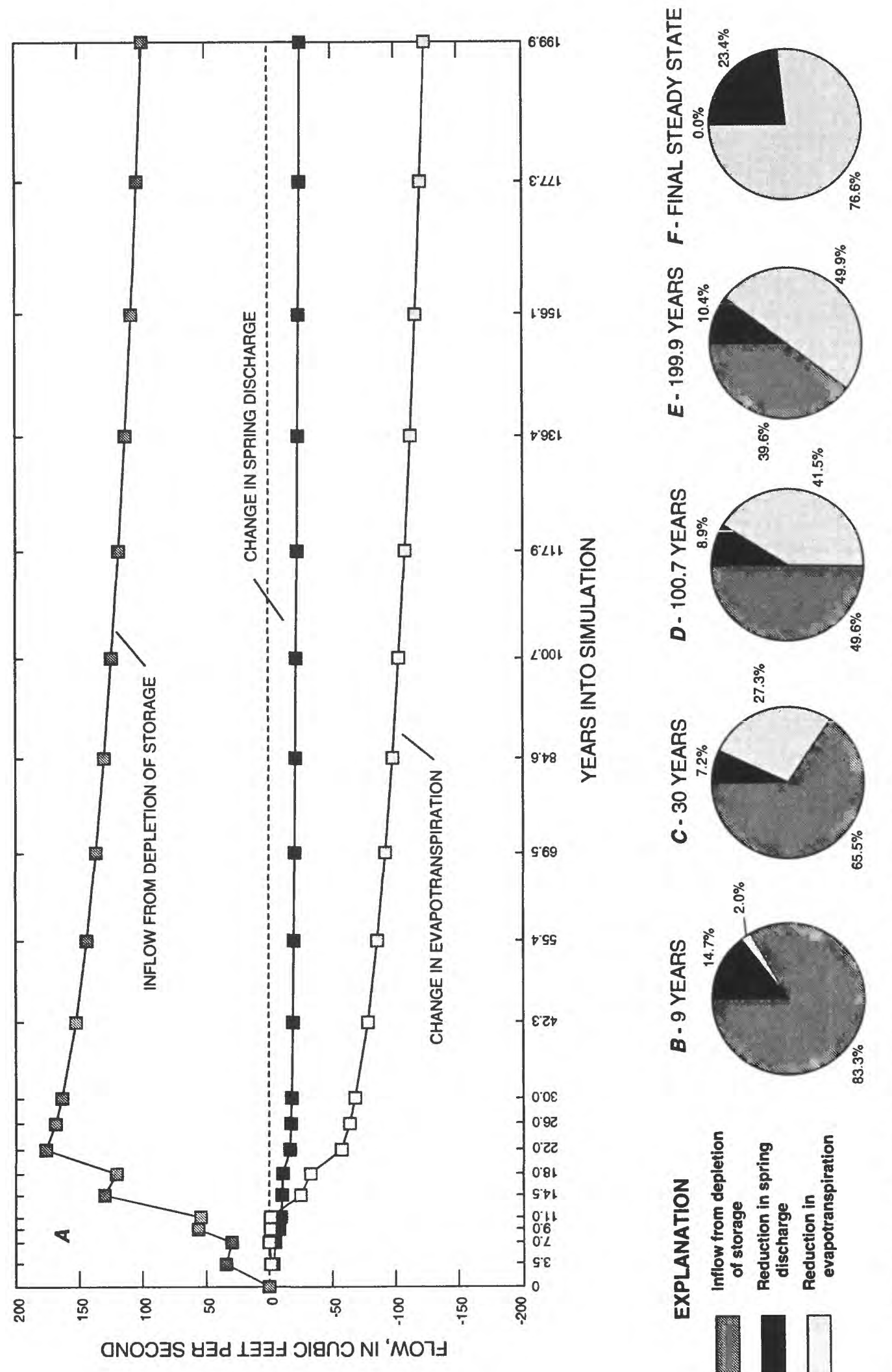

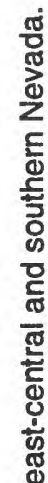
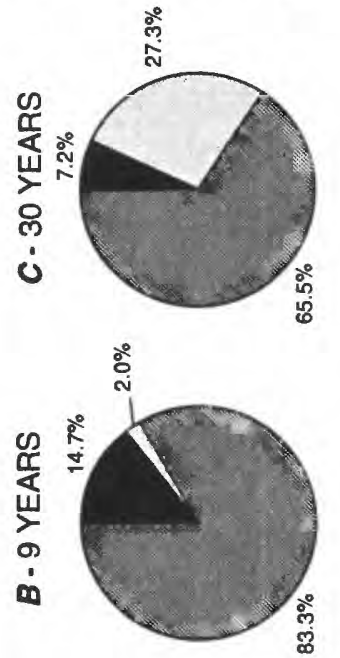

용

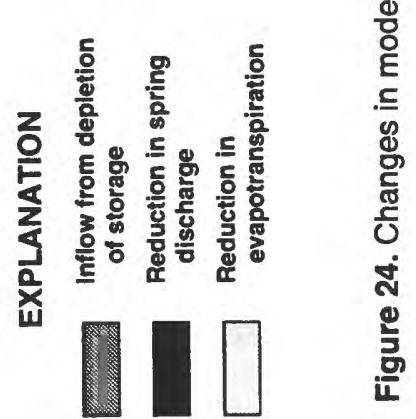




\section{SUMMARY AND CONCLUSIONS}

In 1989, the Las Vegas Valley Water District (LVVWD) filed applications with the Nevada State Engineer for water rights in east-central and southern Nevada. These applications would result in a maximum pumpage of about $180,800 \mathrm{acre}-\mathrm{ft} / \mathrm{yr}$ from 17 basins (LVVWD, written commun., 1992).

In 1991, several Department of the Interior (DOI) bureaus requested that the U.S. Geological Survey simulate possible effects of this pumping on regional flow, as well as on large regional springs, using a two-layer ground-water flow model originally designed to conceptualize regional flow in the carbonate-rock province. The simulations were made using a phased pumping schedule, with ultimate pumpage totaling 180,800 acre-ft/yr.

The simulation of pumping in the carbonate-rock province of the Great Basin indicates that water levels, the flow of regional springs, and ground-water discharge by evapotranspiration would be affected. The upper layer of the model generally represents basin fill and the intervening mountains. Simulated water levels in the basin fill are most strongly affected by localized pumping within the basin. The lower layer of the model, simulating the more extensively connected and confined carbonate-rock aquifer system, generates larger, areally more expansive declines. Several tens of years of pumpage can result in hundreds of feet of simulated water-level declines throughout a large area of the aquifer system.

By extending the pumping schedule for long periods of time, some estimate can be made of when the ground-water system will approach a new equilib- rium. This equilibrium is reached when the change in water-level decline approaches zero, and pumpage is sustained entirely by water diverted from other sources, instead of by depletion of stored ground water.

The simulations also showed that discharge from several regional springs could decrease. Modeling indicated that, after about 100 years of simulation, flow from Muddy River springs; Hiko, Crystal, and Ash Springs; and Ash Meadows springs would all be affected to some degree. Discharge at Muddy River springs decreased the most, with a reduction of about $6 \mathrm{ft}^{3} / \mathrm{s}$ (11 percent). Discharge from the Hiko-CrystalAsh Springs complex decreased about $5 \mathrm{ft}^{3} / \mathrm{s}$ (14 percent), and flow from Ash Meadows springs decreased about $0.5 \mathrm{ft}^{3} / \mathrm{s}$ ( 2 percent).

The modeling also indicated that ground-water discharge by evapotranspiration would probably be affected by the pumpage proposed by LVVWD. The model indicates that the three valleys with the largest proposed pumpage will have the largest decrease in ET rates. In Spring Valley, which is scheduled to have 50,000 acre-ft/yr of ground water pumped, ET decreases about 45.21 cubic feet per second in the first 100 years of pumping (table 4). This is based on the normal estimated ET discharge of 70,000 acre-ft/yr (Rush and Kazmi, 1965, table 7). Railroad and Snake Valleys show similar patterns, with a decrease in ET discharge of 33.02 and 18.23 cubic feet per second, respectively, after about 100 years of pumping.

Irrespective of the obvious limitations of this model, the results of the simulation provide valuable insight regarding the regional-scale response to pumping and can serve as a basis for the development of a more detailed analysis of pumping effects. 


\section{REFERENCES CITED}

Berger, D.L., 1992, Lithologic properties of carbonate-rock aquifers at five test wells in the Coyote Springs Valley area, southern Nevada, as determined from geophysical logs: U.S. Geological Survey Water-Resources Investigations Report 91-4167, 27 p.

Harrill, J.R., Gates, J.S., and Thomas, J.M., 1988, Major ground-water flow systems in the Great Basin region of Nevada, Utah, and adjacent states: U.S. Geological Survey Hydrologic Investigations Atlas HA-694-C, 2 sheets, scale 1:1,000,000.

Harrill, J.R., Welch, A.H., Prudic, D.E., Thomas, J.M., Carman, R.L., Plume, R.W., Gates, J.S., and Mason, J.L., 1983, Aquifer systems in the Great Basin region of Nevada, Utah, and adjacent states-A study plan: U.S. Geological Survey Open-File Report 82-445, 49 p.

Krynine, D.P., and Judd, W.R., 1957, Principles of engineering geology and geotectonics: New York, McGraw-Hill, $750 \mathrm{p}$.

Lohman, S.W., 1972, Ground-water hydraulics: U.S. Geological Survey Professional Paper 708, 70 p.

McDonald, M.G., and Harbaugh, A.W., 1988, A modular three-dimensional finite-difference ground-water flow model: U.S. Geological Survey Techniques of WaterResources Investigations, book 6, chap. A1, 586 p.

Plume, R.W., and Carlton, S.M., 1988, Hydrogeology of the Great Basin region of Nevada, Utah, and adjacent states: U.S. Geological Survey Hydrologic Investigation Atlas HA-694-A, 1 sheet, scale 1:1,000,000.
Prudic, D.E., Harrill, J.R., and Burbey, T.J., 1993, Conceptual evaluation of regional ground-water flow in the carbonate-rock province of the Great Basin, Nevada, Utah, and adjacent states: U.S. Geological Survey Open-File Report 93-170, 103 p.

Rush, F.E., 1968, Index of hydrographic areas in Nevada: Nevada Division of Water Resources, Information Report 6, 38 p.

Rush, F.E., and Kazmi, S.A.T., 1965, Water resources appraisal of Spring Valley, White Pine and Lincoln Counties, Nevada: Nevada Department of Conservation and Natural Resources, Water ResourcesReconnaissance Report 33, 39 p.

Schaefer, D.H., 1993, Documentation of model input and output values for simulation of regional groundwater flow, carbonate-rock province, Nevada, Utah, and adjacent states: U.S. Geological Survey Open-File Report 93-420, 4 p. plus disk.

Snow, D.T., 1979, Packer injection test data from sites of fractured rock: Lawrence Berkeley Laboratories Report LBL-10080, UC-66B, 15 p.

Theis, C.V., 1940, The source of water derived from wells: Civil Engineering, v. 10, no. 5, p. 277-280.

Van Denburgh, A.S., and Rush, F.E., 1974, Water-resources appraisal of Railroad and Penoyer Valleys, east-central Nevada: Nevada Division of Water Resources, Reconnaissance Report 60, 61 p. 

Appendixes 



\section{APPENDIX 1. STORAGE VALUES USED FOR SIMULATION}

(Units are dimensionless; multiply values by 0.005 to obtain acutal value used)

UPPER LAYER

$\begin{array}{lllllllllllllllllllllll}2 & 2 & 2 & 2 & 2 & 2 & 2 & 2 & 2 & 2 & 2 & 2 & 2 & 2 & 2 & 2 & 2 & 2 & 2 & 2 & \text { ROW } & 1\end{array}$

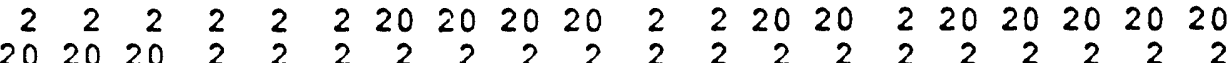

$\begin{array}{rrrrrrrrrrrrrrrrrrrrrr}20 & 20 & 20 & 2 & 2 & 2 & 2 & 2 & 2 & 2 & 2 & 2 & 2 & 2 & 2 & 2 & 2 & 2 & 2 & 2 & & \\ 2 & 2 & 2 & 2 & 2 & 2 & 2 & 2 & 2 & 2 & 2 & 2 & 2 & 2 & 2 & 2 & 2 & 2 & 2 & 2 & \text { ROW } & 2\end{array}$

$\begin{array}{llllllllllllllllllll}2 & 2 & 2 & 2 & 2 & 2 & 20 & 20 & 20 & 20 & 2 & 2 & 20 & 20 & 2 & 2 & 20 & 20 & 20 & 20\end{array}$

$\begin{array}{llllllllllllllllllll}2 & 20 & 20 & 2 & 2 & 2 & 2 & 2 & 2 & 2 & 2 & 2 & 2 & 2 & 2 & 2 & 2 & 2 & 2 & 2\end{array}$

$\begin{array}{llllllllllllllllllllll}2 & 2 & 2 & 2 & 2 & 2 & 2 & 2 & 2 & 2 & 2 & 2 & 2 & 2 & 2 & 2 & 2 & 2 & 2 & 2 & \text { ROW } & 3\end{array}$

$\begin{array}{llllllllllllllllllll}2 & 2 & 2 & 2 & 2 & 2 & 20 & 20 & 2 & 2 & 2 & 2 & 2 & 20 & 20 & 2 & 20 & 20 & 20 & 20\end{array}$

$\begin{array}{llllllllllllllllllll}2 & 2 & 20 & 2 & 2 & 2 & 2 & 2 & 2 & 2 & 2 & 2 & 2 & 2 & 2 & 2 & 2 & 2 & 2 & 2\end{array}$

$\begin{array}{llllllllllllllllllllll}2 & 2 & 2 & 2 & 2 & 2 & 2 & 2 & 2 & 2 & 2 & 2 & 2 & 2 & 2 & 2 & 2 & 2 & 2 & 2 & \text { ROW } & 4\end{array}$

$\begin{array}{llllllllllllllllllll}2 & 2 & 2 & 2 & 2 & 2 & 20 & 2 & 2 & 2 & 2 & 2 & 20 & 20 & 20 & 20 & 20 & 20 & 20 & 20\end{array}$

$\begin{array}{lllllllllllllllllllll}20 & 20 & 20 & 20 & 20 & 2 & 2 & 2 & 2 & 2 & 2 & 2 & 2 & 2 & 2 & 2 & 2 & 2 & 2 & 2\end{array}$

$\begin{array}{llllllllllllllllllllll}2 & 2 & 2 & 2 & 2 & 2 & 2 & 2 & 2 & 2 & 2 & 2 & 2 & 2 & 2 & 2 & 2 & 2 & 2 & 2 & \text { ROW } & 5\end{array}$

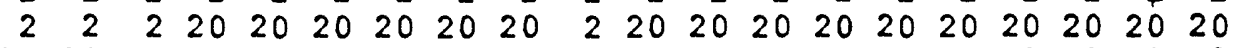

$\begin{array}{lllllllllllllllllllll}20 & 20 & 20 & 20 & 20 & 20 & 2 & 2 & 2 & 2 & 2 & 2 & 2 & 2 & 2 & 2 & 2 & 2 & 2 & 2\end{array}$

$\begin{array}{llllllllllllllllllllll}2 & 2 & 2 & 2 & 2 & 2 & 2 & 2 & 2 & 2 & 2 & 2 & 2 & 2 & 2 & 2 & 2 & 2 & 2 & 2 & \text { ROW } & 6\end{array}$

$\begin{array}{llllllllllllllllllll}2 & 20 & 2 & 2 & 2 & 2 & 20 & 20 & 2 & 2 & 20 & 20 & 2 & 20 & 20 & 20 & 20 & 20 & 20 & 2\end{array}$

$\begin{array}{llllllllllllllllllllll}20 & 20 & 20 & 20 & 2 & 20 & 20 & 20 & 20 & 2 & 2 & 2 & 2 & 2 & 2 & 2 & 2 & 2 & 2 & 2\end{array}$

$\begin{array}{llllllllllllllllllllll}2 & 2 & 2 & 2 & 2 & 2 & 2 & 2 & 2 & 2 & 2 & 2 & 2 & 2 & 2 & 2 & 2 & 2 & 2 & 20 & \text { ROW } & 7\end{array}$

$\begin{array}{llllllllllllllllllll}20 & 20 & 20 & 2 & 2 & 2 & 20 & 20 & 20 & 20 & 2 & 20 & 2 & 10 & 10 & 2 & 20 & 20 & 20 & 20\end{array}$

$\begin{array}{llllllllllllllllllllll}20 & 10 & 20 & 20 & 20 & 2 & 20 & 20 & 20 & 20 & 20 & 2 & 2 & 2 & 2 & 2 & 2 & 2 & 2 & 2\end{array}$

$\begin{array}{llllllllllllllllllllll}2 & 2 & 2 & 2 & 2 & 2 & 2 & 2 & 2 & 2 & 2 & 2 & 2 & 2 & 2 & 2 & 2 & 2 & 20 & 20 & \text { ROW } & 8\end{array}$

$\begin{array}{llllllllllllllllllll}20 & 20 & 20 & 20 & 2 & 20 & 20 & 2 & 20 & 20 & 2 & 20 & 2 & 20 & 20 & 2 & 2 & 20 & 20 & 20\end{array}$

$\begin{array}{lllllllllllllllllllllll}20 & 20 & 20 & 20 & 20 & 2 & 2 & 20 & 20 & 20 & 20 & 20 & 20 & 2 & 2 & 2 & 2 & 2 & 2 & 2\end{array}$

$\begin{array}{llllllllllllllllllllll}2 & 2 & 2 & 2 & 2 & 2 & 2 & 2 & 2 & 2 & 2 & 2 & 2 & 2 & 2 & 2 & 2 & 20 & 20 & 20 & \text { ROW } & 9\end{array}$

$\begin{array}{llllllllllllllllllll}20 & 2 & 20 & 20 & 2 & 2 & 20 & 2 & 20 & 20 & 2 & 20 & 20 & 20 & 20 & 20 & 10 & 20 & 20 & 20\end{array}$

$\begin{array}{llllllllllllllllllllll}20 & 20 & 20 & 20 & 20 & 2 & 20 & 20 & 2 & 20 & 20 & 20 & 20 & 2 & 2 & 2 & 2 & 2 & 2 & 2\end{array}$

$\begin{array}{lllllllllllllllllllllllll}2 & 2 & 2 & 2 & 2 & 2 & 2 & 2 & 2 & 2 & 2 & 2 & 2 & 2 & 2 & 2 & 20 & 20 & 20 & 20 & \text { ROW } & 10\end{array}$ $\begin{array}{llllllllllllllllllll}20 & 2 & 2 & 20 & 20 & 20 & 20 & 2 & 20 & 20 & 2 & 2 & 20 & 2 & 20 & 20 & 20 & 10 & 10 & 10\end{array}$

$\begin{array}{llllllllllllllllllllll}20 & 20 & 20 & 20 & 20 & 2 & 20 & 20 & 2 & 20 & 20 & 20 & 2 & 2 & 2 & 2 & 2 & 2 & 2 & 2\end{array}$

$\begin{array}{llllllllllllllllllllll}2 & 2 & 2 & 2 & 2 & 2 & 2 & 2 & 2 & 2 & 20 & 20 & 2 & 2 & 2 & 20 & 20 & 20 & 20 & 20 & \text { ROW } & 11\end{array}$

$\begin{array}{llllllllllllllllllll}2 & 2 & 2 & 20 & 20 & 20 & 20 & 20 & 2 & 20 & 2 & 2 & 20 & 20 & 20 & 20 & 20 & 10 & 20 & 20\end{array}$

$\begin{array}{llllllllllllllllllllll}20 & 20 & 20 & 20 & 20 & 2 & 20 & 20 & 2 & 2 & 20 & 20 & 2 & 2 & 2 & 20 & 20 & 20 & 2 & 2\end{array}$

$\begin{array}{llllllllllllllllllllllllll}2 & 2 & 2 & 2 & 2 & 2 & 2 & 2 & 20 & 2 & 20 & 20 & 20 & 20 & 20 & 20 & 20 & 20 & 20 & 2 & \text { ROW } & 12\end{array}$

$\begin{array}{llllllllllllllllllll}2 & 20 & 20 & 20 & 20 & 2 & 20 & 2 & 2 & 20 & 20 & 2 & 2 & 20 & 20 & 20 & 20 & 20 & 20 & 20\end{array}$

$\begin{array}{lllllllllllllllllllll}20 & 20 & 20 & 20 & 20 & 2 & 20 & 20 & 20 & 2 & 20 & 20 & 20 & 2 & 2 & 20 & 2 & 20 & 2 & 2\end{array}$

$\begin{array}{llllllllllllllllllll}2 & 2 & 2 & 2 & 2 & 2 & 2 & 2 & 20 & 2 & 2 & 20 & 20 & 20 & 20 & 2 & 20 & 20 & 2 & 2\end{array}$

$\begin{array}{llllllllllllllllllll}2 & 20 & 20 & 20 & 20 & 2 & 2 & 2 & 20 & 20 & 20 & 2 & 2 & 2 & 20 & 20 & 20 & 20 & 20 & 20\end{array}$

$\begin{array}{lllllllllllllllllllll}20 & 20 & 20 & 20 & 20 & 20 & 2 & 20 & 20 & 20 & 2 & 20 & 20 & 10 & 2 & 20 & 20 & 20 & 2 & 2\end{array}$

$\begin{array}{llllllllllllllllllllll}2 & 2 & 2 & 2 & 2 & 2 & 2 & 2 & 20 & 20 & 20 & 20 & 2 & 2 & 20 & 20 & 20 & 20 & 2 & 2\end{array}$

$\begin{array}{llllllllllllllllllll}2 & 20 & 20 & 20 & 20 & 20 & 20 & 20 & 20 & 2 & 20 & 20 & 2 & 20 & 20 & 20 & 20 & 20 & 20 & 20\end{array}$

$\begin{array}{lllllllllllllllllllll}20 & 20 & 20 & 20 & 20 & 20 & 20 & 20 & 20 & 20 & 2 & 20 & 20 & 20 & 2 & 20 & 20 & 20 & 2 & 2\end{array}$

$\begin{array}{llllllllllllllllllll}2 & 2 & 2 & 2 & 2 & 2 & 2 & 2 & 20 & 20 & 2 & 2 & 20 & 2 & 2 & 2 & 20 & 20 & 2 & 2\end{array}$

$\begin{array}{llllllllllllllllllll}10 & 20 & 20 & 20 & 20 & 2 & 20 & 2 & 20 & 2 & 2 & 20 & 2 & 20 & 20 & 2 & 2 & 2 & 20 & 20\end{array}$

$\begin{array}{lllllllllllllllllllll}20 & 20 & 20 & 20 & 20 & 20 & 20 & 20 & 20 & 20 & 20 & 2 & 2 & 20 & 20 & 20 & 2 & 20 & 2 & 2\end{array}$

$\begin{array}{llllllllllllllllllll}2 & 2 & 2 & 2 & 2 & 2 & 2 & 2 & 20 & 20 & 20 & 2 & 20 & 2 & 2 & 20 & 20 & 20 & 2 & 2\end{array}$ $\begin{array}{llllllllllllllllllll}20 & 20 & 2 & 2 & 20 & 2 & 2 & 20 & 10 & 2 & 2 & 2 & 10 & 2 & 20 & 20 & 2 & 2 & 20 & 20\end{array}$ $\begin{array}{lllllllllllllllllllll}20 & 20 & 20 & 20 & 2 & 2 & 20 & 20 & 20 & 2 & 20 & 20 & 2 & 2 & 20 & 20 & 2 & 2 & 20 & 2\end{array}$

$\begin{array}{llllllllllllllllllll}2 & 2 & 2 & 2 & 2 & 2 & 2 & 2 & 20 & 20 & 2.20 & 20 & 20 & 2 & 20 & 20 & 20 & 2 & 2\end{array}$ $\begin{array}{llllllllllllllllllll}10 & 2 & 2 & 2 & 20 & 20 & 2 & 2 & 20 & 20 & 2 & 2 & 20 & 2 & 20 & 20 & 20 & 2 & 20 & 20\end{array}$ $\begin{array}{llllllllllllllllllll}20 & 20 & 20 & 20 & 20 & 2 & 20 & 2 & 2 & 20 & 20 & 20 & 20 & 20 & 20 & 20 & 20 & 20 & 20 & 20\end{array}$ $\begin{array}{llllllllllllllllllll}2 & 2 & 2 & 2 & 2 & 2 & 2 & 2 & 2 & 2 & 2 & 20 & 20 & 20 & 2 & 10 & 2 & 20 & 20 & 2\end{array}$ $\begin{array}{llllllllllllllllllll}20 & 2 & 2 & 2 & 20 & 20 & 2 & 2 & 20 & 2 & 20 & 2 & 2 & 20 & 20 & 20 & 20 & 2 & 20 & 20\end{array}$ $\begin{array}{llllllllllllllllllll}20 & 20 & 2 & 20 & 20 & 2 & 20 & 2 & 20 & 20 & 20 & 20 & 20 & 20 & 20 & 2 & 20 & 20 & 2 & 20\end{array}$ $\begin{array}{llllllllllllllllllll}2 & 2 & 2 & 2 & 2 & 2 & 2 & 2 & 20 & 20 & 20 & 20 & 20 & 20 & 2 & 10 & 2 & 20 & 20 & 2\end{array}$ $\begin{array}{llllllllllllllllllll}2 & 20 & 20 & 2 & 20 & 2 & 2 & 20 & 20 & 2 & 20 & 2 & 20 & 20 & 2 & 2 & 2 & 2 & 20 & 20\end{array}$ ROW 13

ROW 14

ROW 15

ROW 16

ROW 17

ROW 18

ROW 19

$\begin{array}{llllllllllllllllllll}20 & 20 & 2 & 20 & 20 & 2 & 2 & 20 & 20 & 2 & 20 & 20 & 20 & 20 & 20 & 20 & 2 & 20 & 2 & 2\end{array}$ 


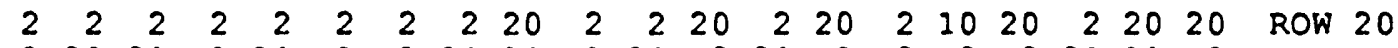

$\begin{array}{llllllllllllllllllll}2 & 20 & 20 & 2 & 20 & 2 & 2 & 20 & 20 & 2 & 20 & 2 & 20 & 2 & 2 & 2 & 2 & 20 & 20 & 2\end{array}$

$\begin{array}{lllllllllllllllllllll}2 & 2 & 20 & 2 & 20 & 20 & 2 & 2 & 20 & 20 & 20 & 20 & 20 & 20 & 20 & 20 & 2 & 20 & 20 & 20\end{array}$

$\begin{array}{lrrrrrrrrrrrrrrrrrrr}2 & 2 & 2 & 2 & 2 & 2 & 2 & 2 & 10 & 2 & 2 & 2 & 2 & 2 & 2 & 20 & 20 & 2 & 20 & 2 \\ 2 & 20 & 2 & 2 & 20 & 20 & 2 & 2 & 20 & 2 & 2 & 20 & 20 & 20 & 2 & 2 & 20 & 20 & 20 & 2\end{array}$

$\begin{array}{lllllllllllllllllllllll}2 & 20 & 20 & 20 & 2 & 20 & 20 & 2 & 20 & 20 & 20 & 20 & 20 & 20 & 20 & 20 & 20 & 20 & 20 & 20\end{array}$

$\begin{array}{llllllllllllllllllll}2 & 2 & 2 & 2 & 2 & 2 & 2 & 2 & 20 & 2 & 20 & 20 & 20 & 20 & 20 & 20 & 20 & 2 & 10 & 2\end{array}$

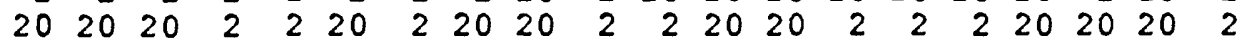

$\begin{array}{llllllllllllllllllll}2 & 20 & 10 & 20 & 2 & 2 & 20 & 20 & 20 & 20 & 20 & 20 & 10 & 20 & 20 & 20 & 20 & 2 & 2 & 20\end{array}$

$\begin{array}{llllllllllllllllllll}2 & 2 & 2 & 2 & 2 & 2 & 20 & 20 & 2 & 2 & 20 & 20 & 20 & 20 & 20 & 20 & 20 & 2 & 20 & 20\end{array}$

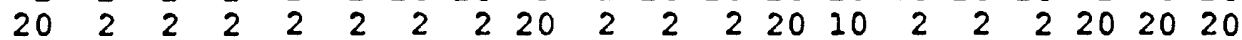

$2 \begin{array}{lllllllllllllllllllll}2 & 20 & 20 & 2 & 20 & 20 & 20 & 20 & 20 & 10 & 10 & 10 & 2 & 20 & 20 & 20 & 20 & 20 & 2\end{array}$

$\begin{array}{rrrrrrrrrrrrrrrrrrrr}2 & 2 & 2 & 2 & 2 & 2 & 20 & 2 & 2 & 20 & 20 & 20 & 20 & 20 & 2 & 2 & 2 & 2 & 20 & 2 \\ 20 & 2 & 2 & 2 & 20 & 2 & 2 & 2 & 20 & 2 & 2 & 2 & 20 & 20 & 2 & 2 & 2 & 20 & 20 & 2\end{array}$

$\begin{array}{lllllllllllllllllllll}2 & 2 & 20 & 20 & 2 & 2 & 20 & 20 & 20 & 20 & 20 & 20 & 20 & 2 & 2 & 20 & 20 & 20 & 20 & 2\end{array}$

$\begin{array}{llllllllllllllllllll}2 & 2 & 2 & 2 & 2 & 2 & 2 & 2 & 20 & 20 & 2 & 2 & 20 & 20 & 20 & 2 & 20 & 20 & 20 & 2\end{array}$

$\begin{array}{llllllllllllllllllll}20 & 2 & 2 & 2 & 20 & 2 & 2 & 2 & 20 & 20 & 20 & 2 & 20 & 20 & 2 & 20 & 20 & 20 & 20 & 2\end{array}$

$\begin{array}{llllllllllllllllllll}20 & 2 & 2 & 2 & 2 & 2 & 20 & 10 & 20 & 2 & 20 & 20 & 20 & 2 & 20 & 20 & 2 & 2 & 2 & 2\end{array}$

$\begin{array}{lllllllllllllllllllll}2 & 2 & 2 & 2 & 2 & 2 & 20 & 20 & 20 & 20 & 2 & 2 & 20 & 20 & 20 & 2 & 20 & 20 & 2 & 2\end{array}$

$\begin{array}{lllllllllllllllllllll}2 & 2 & 2 & 2 & 20 & 20 & 20 & 20 & 2 & 20 & 20 & 2 & 20 & 20 & 2 & 2 & 20 & 20 & 20 & 20\end{array}$

$\begin{array}{lllllllllllllllllllll}20 & 20 & 20 & 2 & 2 & 2 & 20 & 10 & 20 & 2 & 20 & 20 & 20 & 20 & 20 & 20 & 2 & 2 & 2 & 2\end{array}$

$\begin{array}{lllllllllllllllllllll}2 & 2 & 2 & 2 & 2 & 20 & 20 & 20 & 2 & 20 & 2 & 2 & 2 & 20 & 2 & 2 & 20 & 20 & 2 & 2\end{array}$

$\begin{array}{llllllllllllllllllll}20 & 20 & 2 & 2 & 2 & 2 & 20 & 20 & 2 & 20 & 20 & 2 & 20 & 20 & 20 & 2 & 2 & 20 & 20 & 2\end{array}$

$\begin{array}{llllllllllllllllllll}2 & 20 & 20 & 2 & 20 & 2 & 2 & 10 & 20 & 20 & 2 & 2 & 2 & 20 & 2 & 2 & 2 & 2 & 2 & 2\end{array}$

$\begin{array}{llllllllllllllllllll}2 & 2 & 2 & 2 & 2 & 20 & 20 & 2 & 2 & 20 & 20 & 2 & 2 & 2 & 2 & 20 & 20 & 2 & 2 & 20\end{array}$

$\begin{array}{llllllllllllllllllll}2 & 20 & 20 & 2 & 2 & 20 & 2 & 20 & 2 & 2 & 2 & 2 & 20 & 20 & 20 & 2 & 2 & 20 & 20 & 20\end{array}$

$\begin{array}{llllllllllllllllllll}20 & 2 & 20 & 2 & 2 & 20 & 10 & 20 & 2 & 20 & 20 & 20 & 20 & 2 & 2 & 2 & 2 & 2 & 2 & 2\end{array}$

$\begin{array}{lllllllllllllllllllll}2 & 2 & 2 & 2 & 20 & 10 & 20 & 2 & 2 & 20 & 20 & 2 & 2 & 20 & 2 & 2 & 20 & 2 & 20 & 2\end{array}$

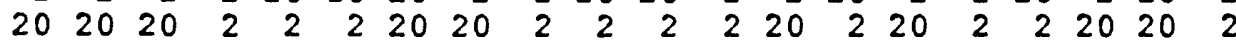

$\begin{array}{llllllllllllllllllll}20 & 2 & 20 & 20 & 2 & 20 & 20 & 2 & 20 & 20 & 20 & 20 & 2 & 2 & 2 & 2 & 2 & 2 & 2 & 2\end{array}$

$\begin{array}{llllllllllllllllllll}2 & 2 & 2 & 2 & 20 & 10 & 20 & 2 & 2 & 10 & 2 & 2 & 20 & 20 & 2 & 2 & 2 & 2 & 20 & 2\end{array}$

$\begin{array}{llllllllllllllllllll}2 & 20 & 20 & 20 & 2 & 2 & 20 & 20 & 2 & 2 & 20 & 2 & 20 & 20 & 2 & 20 & 2 & 20 & 20 & 2\end{array}$

$\begin{array}{llllllllllllllllllll}2 & 2 & 20 & 20 & 2 & 20 & 20 & 2 & 20 & 20 & 20 & 20 & 2 & 20 & 20 & 2 & 2 & 2 & 2 & 2\end{array}$

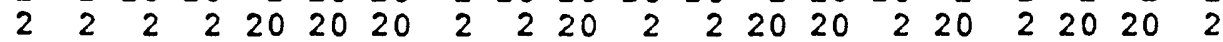

$\begin{array}{llllllllllllllllllll}2 & 20 & 20 & 20 & 2 & 2 & 20 & 20 & 20 & 2 & 2 & 2 & 20 & 20 & 2 & 2 & 2 & 20 & 20 & 2\end{array}$

$\begin{array}{llllllllllllllllllll}2 & 2 & 20 & 20 & 2 & 2 & 20 & 2 & 2 & 20 & 20 & 20 & 2 & 20 & 20 & 2 & 2 & 2 & 2 & 2\end{array}$

$\begin{array}{llllllllllllllllllll}2 & 2 & 2 & 2 & 2 & 20 & 20 & 2 & 2 & 20 & 2 & 2 & 20 & 2 & 2 & 20 & 2 & 20 & 2 & 2\end{array}$

$\begin{array}{llllllllllllllllllll}20 & 10 & 10 & 20 & 2 & 2 & 20 & 20 & 20 & 2 & 20 & 2 & 2 & 20 & 20 & 2 & 2 & 2 & 20 & 20\end{array}$

$\begin{array}{llllllllllllllllllllll}2 & 2 & 20 & 20 & 2 & 2 & 2 & 20 & 20 & 20 & 20 & 20 & 2 & 2 & 2 & 2 & 2 & 2 & 2 & 2\end{array}$

$\begin{array}{llllllllllllllllllll}2 & 2 & 2 & 2 & 2 & 20 & 2 & 2 & 2 & 20 & 2 & 2 & 2 & 2 & 20 & 20 & 20 & 20 & 2 & 2\end{array}$

$\begin{array}{llllllllllllllllllll}20 & 10 & 10 & 2 & 2 & 20 & 20 & 20 & 20 & 2 & 20 & 20 & 2 & 20 & 20 & 2 & 2 & 2 & 20 & 2\end{array}$

$\begin{array}{llllllllllllllllllll}20 & 2 & 2 & 20 & 2 & 2 & 20 & 20 & 20 & 2 & 2 & 2 & 2 & 2 & 20 & 2 & 2 & 2 & 2 & 2\end{array}$

$\begin{array}{llllllllllllllllllll}2 & 2 & 2 & 2 & 20 & 2 & 2 & 2 & 20 & 2 & 2 & 20 & 2 & 2 & 2 & 20 & 2 & 2 & 2 & 20\end{array}$

$\begin{array}{llllllllllllllllllll}20 & 20 & 20 & 2 & 2 & 20 & 20 & 20 & 2 & 20 & 2 & 20 & 2 & 2 & 20 & 20 & 2 & 2 & 20 & 2\end{array}$

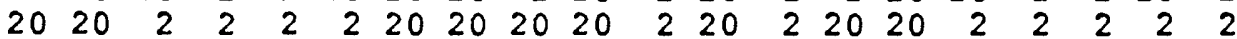

$\begin{array}{llllllllllllllllllllll}2 & 2 & 20 & 20 & 20 & 20 & 20 & 20 & 20 & 2 & 2 & 20 & 20 & 2 & 2 & 20 & 20 & 2 & 20 & 20\end{array}$

$\begin{array}{llllllllllllllllllll}20 & 20 & 2 & 2 & 20 & 20 & 20 & 20 & 20 & 20 & 2 & 20 & 20 & 20 & 20 & 20 & 20 & 2 & 2 & 2\end{array}$

$\begin{array}{lllllllllllllllllllllll}2 & 20 & 2 & 2 & 20 & 20 & 20 & 20 & 20 & 20 & 20 & 20 & 20 & 20 & 2 & 2 & 2 & 2 & 2 & 2\end{array}$

$\begin{array}{llllllllllllllllllll}2 & 2 & 2 & 20 & 20 & 2 & 2 & 20 & 2 & 2 & 2 & 20 & 20 & 20 & 2 & 20 & 20 & 2 & 20 & 20\end{array}$

$\begin{array}{llllllllllllllllllll}2 & 2 & 2 & 2 & 20 & 20 & 20 & 20 & 2 & 2 & 20 & 2 & 20 & 20 & 2 & 20 & 20 & 20 & 20 & 2\end{array}$

$\begin{array}{lllllllllllllllllllll}2 & 2 & 20 & 20 & 20 & 20 & 20 & 20 & 20 & 20 & 20 & 20 & 2 & 2 & 2 & 2 & 2 & 2 & 2 & 2\end{array}$

$\begin{array}{llllllllllllllllllll}2 & 2 & 20 & 20 & 20 & 2 & 2 & 20 & 2 & 2 & 2 & 2 & 20 & 20 & 2 & 20 & 2 & 2 & 20 & 20\end{array}$

$\begin{array}{rrrrrrrrrrrrrrrrrrrr}2 & 2 & 2 & 20 & 20 & 2 & 10 & 20 & 2 & 2 & 20 & 2 & 20 & 20 & 2 & 20 & 20 & 20 & 2 & 2\end{array}$

$\begin{array}{llllllllllllllllllll}20 & 2 & 20 & 20 & 20 & 20 & 20 & 2 & 2 & 20 & 20 & 20 & 2 & 2 & 2 & 2 & 2 & 2 & 2 & 2\end{array}$

$\begin{array}{lllllllllllllllllllll}2 & 20 & 20 & 2 & 20 & 2 & 2 & 20 & 20 & 20 & 20 & 20 & 20 & 2 & 2 & 20 & 2 & 2 & 20 & 20\end{array}$

$\begin{array}{lllllllllllllllllllll}2 & 20 & 20 & 20 & 20 & 2 & 20 & 10 & 2 & 2 & 2 & 2 & 10 & 20 & 2 & 2 & 20 & 20 & 2 & 2\end{array}$

$\begin{array}{llllllllllllllllllll}20 & 2 & 2 & 2 & 2 & 20 & 2 & 2 & 2 & 2 & 2 & 2 & 2 & 2 & 2 & 2 & 2 & 2 & 2 & 2\end{array}$

$\begin{array}{llllllllllllllllllll}20 & 10 & 20 & 2 & 20 & 20 & 2 & 20 & 20 & 20 & 20 & 20 & 20 & 2 & 2 & 2 & 20 & 20 & 20 & 20\end{array}$

$\begin{array}{llllllllllllllllllll}2 & 20 & 20 & 20 & 2 & 20 & 2 & 2 & 2 & 2^{\prime} & 2 & 2 & 20 & 2 & 2 & 2 & 2 & 2 & 2 & 2\end{array}$

$\begin{array}{llllllllllllllllllll}2 & 2 & 2 & 2 & 2 & 20 & 2 & 2 & 2 & 2 & 2 & 2 & 2 & 2 & 2 & 2 & 2 & 2 & 2 & 2\end{array}$

$\begin{array}{llllllllllllllllllll}20 & 20 & 2 & 2 & 10 & 20 & 20 & 2 & 10 & 20 & 20 & 20 & 20 & 20 & 20 & 20 & 2 & 20 & 20 & 20\end{array}$

ROW 21

ROW 22

ROW 23

ROW 24

ROW 25

ROW 26

ROW 27

ROW 28

ROW 29

ROW 30

ROW 31

ROW 32

ROW 33

ROW 34

ROW 35

ROW 36

ROW 37

ROW 38

ROW 39

ROW 40

$\begin{array}{llllllllllllllllllllll}2 & 20 & 20 & 20 & 2 & 2 & 2 & 2 & 20 & 20 & 2 & 2 & 20 & 2 & 2 & 2 & 2 & 2 & 2 & 2\end{array}$ 
$\begin{array}{rrrrrrrrrrrrrrrrrrrr}2 & 2 & 2 & 2 & 2 & 2 & 2 & 2 & 2 & 2 & 2 & 2 & 2 & 2 & 2 & 2 & 2 & 2 & 2 & 2 \\ 2 & 2 & 10 & 20 & 2 & 2 & 20 & 2 & 2 & 20 & 2 & 2 & 10 & 20 & 20 & 20 & 2 & 20 & 20 & 2\end{array}$ $\begin{array}{llllllllllllllllllll}20 & 20 & 2 & 2 & 20 & 20 & 2 & 2 & 20 & 2 & 2 & 2 & 20 & 20 & 2 & 2 & 2 & 2 & 2 & 2\end{array}$ $\begin{array}{llllllllllllllllllll}2 & 2 & 2 & 2 & 2 & 2 & 2 & 2 & 2 & 2 & 2 & 2 & 2 & 2 & 2 & 2 & 2 & 2 & 2 & 2\end{array}$ $\begin{array}{llllllllllllllllllll}2 & 20 & 10 & 20 & 2 & 2 & 2 & 20 & 20 & 20 & 20 & 2 & 2 & 2 & 2 & 20 & 2 & 20 & 20 & 2\end{array}$ $\begin{array}{llllllllllllllllllll}2 & 20 & 2 & 2 & 2 & 20 & 20 & 2 & 2 & 20 & 2 & 2 & 10 & 2 & 2 & 2 & 2 & 2 & 2 & 2\end{array}$ $\begin{array}{llllllllllllllllllll}20 & 20 & 20 & 2 & 2 & 2 & 2 & 2 & 2 & 2 & 2 & 2 & 2 & 2 & 2 & 2 & 2 & 2 & 2 & 2\end{array}$ $\begin{array}{llllllllllllllllllll}2 & 2 & 2 & 2 & 2 & 20 & 2 & 20 & 20 & 2 & 2 & 2 & 2 & 20 & 20 & 20 & 2 & 2 & 20 & 2\end{array}$

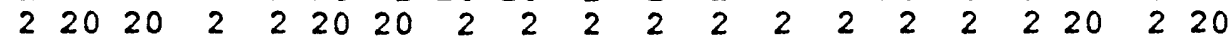
$\begin{array}{llllllllllllllllllll}2 & 20 & 20 & 20 & 2 & 2 & 2 & 2 & 2 & 2 & 2 & 2 & 2 & 2 & 2 & 2 & 2 & 2 & 2 & 2\end{array}$ $\begin{array}{llllllllllllllllllll}2 & 2 & 20 & 2 & 2 & 20 & 20 & 20 & 20 & 2 & 2 & 2 & 2 & 2 & 2 & 2 & 2 & 2 & 2 & 2\end{array}$ $\begin{array}{llllllllllllllllllll}2 & 20 & 20 & 20 & 2 & 2 & 20 & 20 & 2 & 2 & 2 & 2 & 2 & 2 & 2 & 2 & 2 & 20 & 2 & 20\end{array}$ $\begin{array}{lllllllllllllllllllll}2 & 20 & 20 & 20 & 20 & 2 & 2 & 2 & 2 & 2 & 2 & 2 & 2 & 2 & 2 & 2 & 2 & 2 & 2 & 2\end{array}$

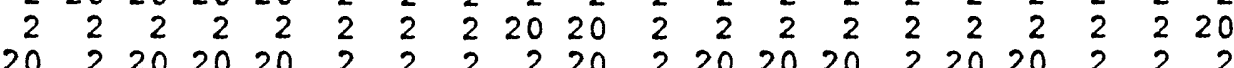
$\begin{array}{lllllllllllllllllllll}20 & 20 & 20 & 20 & 20 & 2 & 2 & 2 & 2 & 2 & 2 & 2 & 2 & 2 & 2 & 2 & 2 & 2 & 2 & 2\end{array}$ $\begin{array}{llllllllllllllllllll}2 & 2 & 2 & 20 & 20 & 2 & 2 & 20 & 20 & 20 & 20 & 20 & 20 & 2 & 2 & 2 & 2 & 2 & 2 & 20\end{array}$ $\begin{array}{llllllllllllllllllll}20 & 20 & 2 & 2 & 2 & 20 & 2 & 20 & 2 & 10 & 10 & 2 & 20 & 20 & 2 & 2 & 20 & 20 & 20 & 20\end{array}$ $\begin{array}{lllllllllllllllllllll}20 & 20 & 20 & 20 & 2 & 2 & 2 & 2 & 2 & 2 & 2 & 2 & 2 & 2 & 2 & 2 & 2 & 2 & 2 & 2\end{array}$

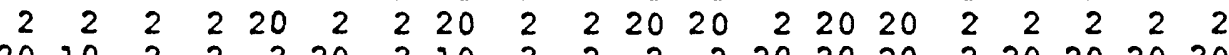
$\begin{array}{rrrrrrrrrrrrrrrrrrrr}20 & 10 & 2 & 2 & 2 & 20 & 2 & 10 & 2 & 2 & 2 & 2 & 20 & 20 & 20 & 2 & 20 & 20 & 20 & 20 \\ 20 & 20 & 2 & 2 & 2 & 2 & 2 & 2 & 2 & 2 & 2 & 2 & 2 & 2 & 2 & 2 & 2 & 2 & 2 & 2\end{array}$

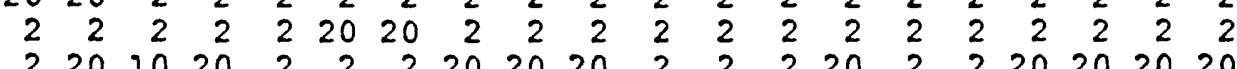

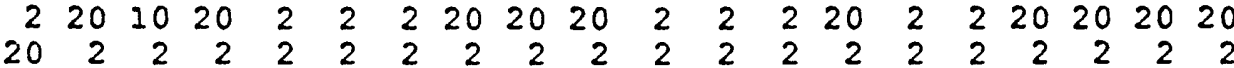
$\begin{array}{rlllllllllllllllllll}2 & 2 & 2 & 2 & 2 & 2 & 2 & 20 & 2 & 2 & 2 & 2 & 20 & 20 & 20 & 20 & 2 & 20 & 2 & 2\end{array}$ $\begin{array}{llllllllllllllllllll}2 & 2 & 2 & 2 & 2 & 20 & 10 & 20 & 2 & 20 & 2 & 2 & 2 & 20 & 2 & 20 & 20 & 2 & 2 & 2\end{array}$

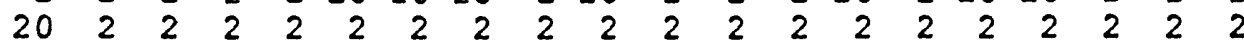
$\begin{array}{llllllllllllllllllll}2 & 2 & 2 & 2 & 2 & 2 & 2 & 2 & 20 & 20 & 2 & 2 & 2 & 20 & 20 & 20 & 20 & 20 & 20 & 2\end{array}$ $\begin{array}{llllllllllllllllllllll}2 & 2 & 20 & 20 & 20 & 20 & 20 & 20 & 20 & 20 & 2 & 20 & 2 & 20 & 20 & 20 & 20 & 2 & 2 & 20\end{array}$ $\begin{array}{llllllllllllllllllll}20 & 2 & 2 & 2 & 2 & 2 & 2 & 2 & 2 & 2 & 2 & 2 & 2 & 2 & 2 & 2 & 2 & 2 & 2 & 2\end{array}$ $\begin{array}{llllllllllllllllllll}2 & 2 & 2 & 2 & 2 & 2 & 2 & 2 & 20 & 20 & 20 & 20 & 20 & 2 & 2 & 20 & 20 & 20 & 20 & 20\end{array}$

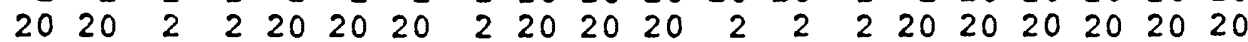
$\begin{array}{llllllllllllllllllll}20 & 2 & 2 & 2 & 2 & 2 & 2 & 2 & 2 & 2 & 2 & 2 & 2 & 2 & 2 & 2 & 2 & 2 & 2 & 2\end{array}$ $\begin{array}{rrrrrrrrrrrrrrrrrrrr}2 & 2 & 2 & 2 & 2 & 2 & 2 & 2 & 2 & 2 & 2 & 20 & 10 & 20 & 2 & 2 & 20 & 20 & 20 & 20 \\ 20 & 2 & 20 & 2 & 20 & 2 & 2 & 2 & 2 & 20 & 20 & 20 & 20 & 20 & 20 & 20 & 20 & 20 & 20 & 20\end{array}$ $\begin{array}{llllllllllllllllllll}20 & 2 & 2 & 2 & 2 & 2 & 2 & 2 & 2 & 2 & 2 & 2 & 2 & 2 & 2 & 2 & 2 & 2 & 2 & 2\end{array}$ $\begin{array}{llllllllllllllllllll}2 & 2 & 2 & 2 & 2 & 2 & 2 & 2 & 2 & 2 & 2 & 2 & 20 & 20 & 20 & 2 & 2 & 20 & 20 & 2\end{array}$ $\begin{array}{llllllllllllllllllll}2 & 2 & 10 & 20 & 2 & 2 & 2 & 2 & 2 & 2 & 20 & 20 & 20 & 20 & 2 & 20 & 20 & 20 & 2 & 2\end{array}$

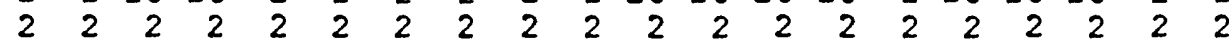
$\begin{array}{llllllllllllllllllll}2 & 2 & 2 & 2 & 2 & 2 & 2 & 2 & 2 & 2 & 2 & 2 & 2 & 20 & 20 & 20 & 2 & 2 & 2 & 2\end{array}$ $\begin{array}{llllllllllllllllllll}2 & 2 & 20 & 20 & 20 & 20 & 2 & 2 & 2 & 20 & 2 & 20 & 20 & 20 & 2 & 2 & 2 & 20 & 2 & 2\end{array}$ $\begin{array}{llllllllllllllllllll}2 & 2 & 2 & 2 & 2 & 2 & 2 & 2 & 2 & 2 & 2 & 2 & 2 & 2 & 2 & 2 & 2 & 2 & 2 & 2\end{array}$ $\begin{array}{llllllllllllllllllll}2 & 2 & 2 & 2 & 2 & 2 & 2 & 2 & 2 & 2 & 2 & 2 & 2 & 20 & 20 & 2 & 2 & 2 & 2 & 2\end{array}$ $\begin{array}{llllllllllllllllllll}2 & 20 & 2 & 10 & 20 & 20 & 20 & 20 & 2 & 2 & 20 & 2 & 2 & 20 & 2 & 20 & 20 & 2 & 2 & 2\end{array}$ $\begin{array}{llllllllllllllllllll}2 & 2 & 2 & 2 & 2 & 2 & 2 & 2 & 2 & 2 & 2 & 2 & 2 & 2 & 2 & 2 & 2 & 2 & 2 & 2\end{array}$ $\begin{array}{rrrrrrrrrrrrrrrrrrrr}2 & 2 & 2 & 2 & 2 & 2 & 2 & 2 & 2 & 2 & 2 & 2 & 2 & 2 & 20 & 20 & 2 & 2 & 2 & 20 \\ 20 & 20 & 2 & 20 & 20 & 20 & 20 & 20 & 2 & 2 & 2 & 20 & 2 & 2 & 20 & 20 & 2 & 2 & 2 & 2\end{array}$ $\begin{array}{llllllllllllllllllll}2 & 2 & 2 & 2 & 2 & 2 & 2 & 2 & 2 & 2 & 2 & 2 & 2 & 2 & 2 & 2 & 2 & 2 & 2 & 2\end{array}$ $\begin{array}{rrrrrrrrrrrrrrrrrrrr}2 & 2 & 2 & 2 & 2 & 2 & 2 & 2 & 2 & 2 & 2 & 2 & 2 & 2 & 2 & 20 & 20 & 2 & 2 & 2 \\ 20 & 20 & 2 & 20 & 2 & 2 & 20 & 20 & 10 & 20 & 20 & 20 & 20 & 2 & 20 & 20 & 2 & 2 & 2 & 2\end{array}$ $\begin{array}{llllllllllllllllllll}2 & 2 & 2 & 2 & 2 & 2 & 2 & 2 & 2 & 2 & 2 & 2 & 2 & 2 & 2 & 2 & 2 & 2 & 2 & 2\end{array}$

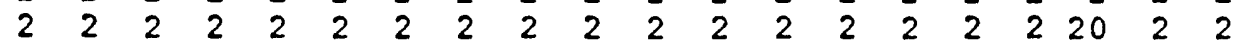
$\begin{array}{llllllllllllllllllll}2 & 20 & 20 & 20 & 2 & 20 & 20 & 2 & 2 & 2 & 2 & 20 & 2 & 2 & 2 & 2 & 20 & 2 & 2 & 2\end{array}$ $\begin{array}{llllllllllllllllllll}2 & 2 & 2 & 2 & 2 & 2 & 2 & 2 & 2 & 2 & 2 & 2 & 2 & 2 & 2 & 2 & 2 & 2 & 2 & 2\end{array}$ $\begin{array}{rrrrrrrrrrrrrrrrrrrr}2 & 2 & 2 & 2 & 2 & 2 & 2 & 2 & 2 & 2 & 2 & 2 & 2 & 2 & 2 & 2 & 2 & 2 & 20 & 20\end{array}$ $\begin{array}{llllllllllllllllllll}2 & 2 & 2 & 2 & 2 & 2 & 2 & 2 & 2 & 2 & 2 & 2 & 2 & 2 & 2 & 2 & 2 & 2 & 2 & 2\end{array}$

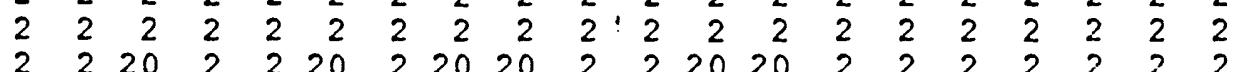
$\begin{array}{llllllllllllllllllll}2 & 2 & 2 & 2 & 2 & 2 & 2 & 2 & 2 & 2 & 2 & 2 & 2 & 2 & 2 & 2 & 2 & 2 & 2 & 2\end{array}$ $\begin{array}{llllllllllllllllllll}2 & 2 & 2 & 2 & 2 & 2 & 2 & 2 & 2 & 2 & 2 & 2 & 2 & 2 & 2 & 2 & 2 & 2 & 2 & 2\end{array}$
ROW 41

ROW 42

ROW 43

ROW 44

ROW 45

ROW 46

ROW 47

ROW 48

ROW 49

ROW 50

ROW 51

ROW 52

ROW 53

ROW 54

ROW 55

ROW 56

ROW 57

ROW 58

ROW 59

ROW 60

ROW 61 


\section{APPENDIX 1. STORAGE VALUES USED FOR SIMULATION-Continued}

$\begin{array}{rlrrrrrrrrrrrrrrrrrr}2 & 2 & 2 & 10 & 2 & 2 & 2 & 2 & 20 & 20 & 20 & 20 & 2 & 2 & 2 & 2 & 2 & 2 & 2 & 2 \\ 2 & 2 & 2 & 2 & 2 & 2 & 2 & 2 & 2 & 2 & 2 & 2 & 2 & 2 & 2 & 2 & 2 & 2 & 2 & 2 \\ \text { LOWER LAYER USES A CONSTANT VALUE } & \text { OF } & 6 & \text { X } & 10-4 & \end{array}$




\section{APPENDIX 2. STARTING HEADS USED FOR SIMULATION}

(Units are feet above sea level)

UPPER LAYER (LAYER 1)

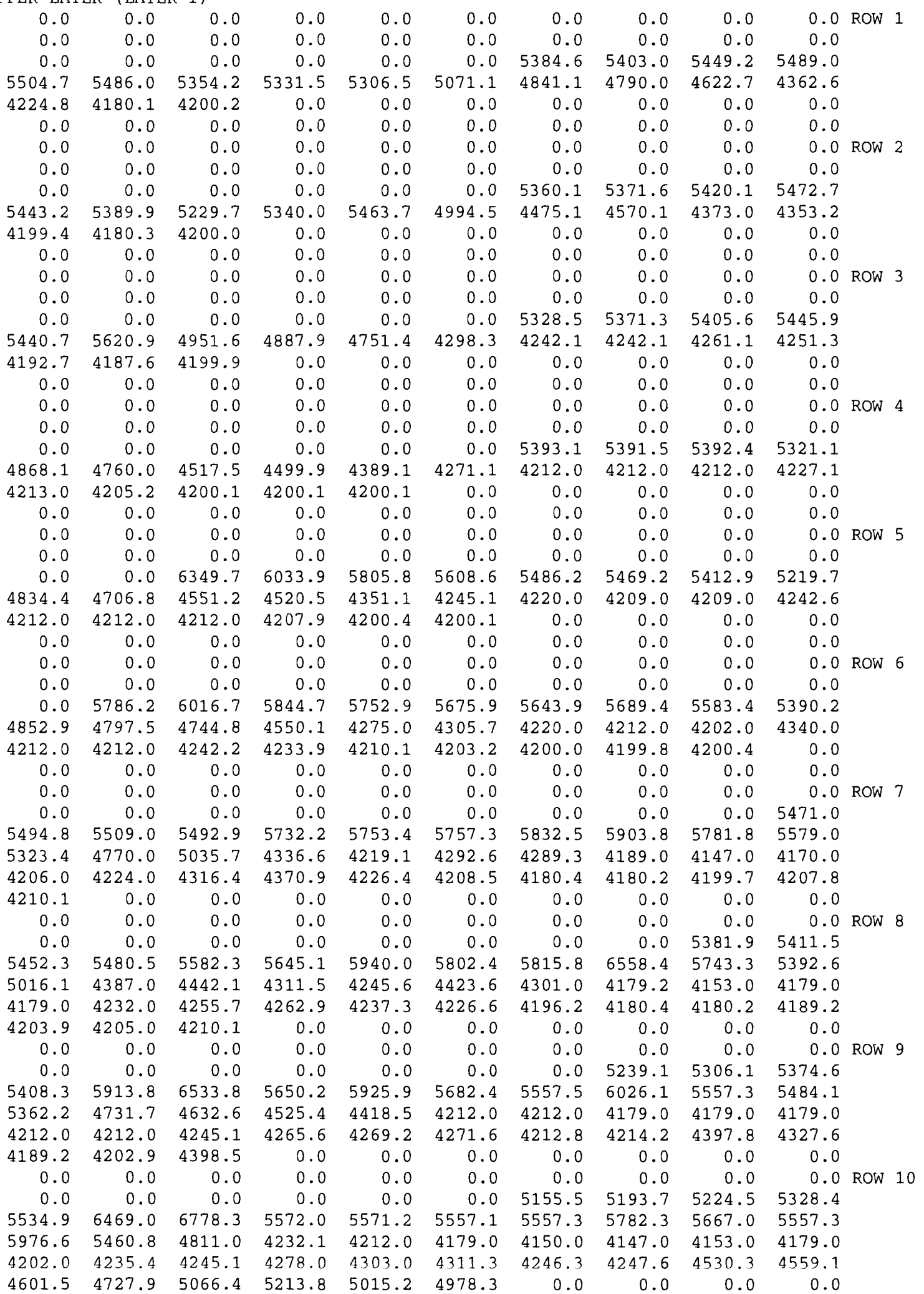


APPENDIX 2. STARTING HEADS USED FOR SIMULATION-Continued

\begin{tabular}{|c|c|c|c|c|c|c|c|c|c|c|c|}
\hline 0.0 & 0.0 & 0.0 & 0.0 & 0.0 & 0.0 & 0.0 & 0.0 & 0.0 & 0.0 & ROW & 11 \\
\hline 253.4 & 5257.9 & 5274.7 & 5244.1 & 5443.2 & 5093.6 & 5109.8 & 5231.4 & 5335.6 & 5426.8 & & \\
\hline 538.3 & 6426.9 & 5975.3 & 5810.7 & 5577.6 & 5626.3 & 5557.9 & 5679.5 & 5683.9 & 5557.2 & & \\
\hline 5702.7 & 6431.1 & 5018.0 & 4245.1 & 4212.0 & 4206.0 & 4173.0 & 4153.0 & 4160.0 & 4173.0 & & \\
\hline 1212.0 & 4225.1 & 4245.3 & 4278.0 & 4323.2 & 4369.3 & 4357.6 & 4376.4 & 4506.6 & 5331.5 & & \\
\hline 948.8 & 4942.9 & 5264.0 & 5304.0 & 5028.6 & 4895.8 & 4614.9 & 4533.0 & 0.0 & 0.0 & & \\
\hline 0.0 & 0.0 & 0.0 & 0.0 & 0.0 & 0.0 & 0.0 & 0.0 & 4669.0 & 4673.4 & ROW & 12 \\
\hline 4896.5 & 4984.7 & 4980.7 & 4980.5 & 5028.7 & 5065.7 & 5199.5 & 5301.6 & 5699.3 & 7046.8 & & \\
\hline 7507.8 & 6102.1 & 5953.0 & 5913.7 & 5900.4 & 5909.2 & 5858.2 & 5843.0 & 5778.0 & 5548.2 & & \\
\hline 5598.6 & 6301.4 & 4963.7 & 4498.0 & 4137.0 & 4219.0 & 4212.0 & 4186.0 & 4179.0 & 4206.0 & & \\
\hline 4212.0 & 4216.5 & 4213.5 & 4250.2 & 4308.1 & 4389.1 & 4393.5 & 4412.1 & 4586.6 & 5349.8 & & \\
\hline 5157.1 & 5099.4 & 5115.8 & 5149.3 & 4995.4 & 4830.7 & 4631.5 & 4524.2 & 0.0 & 0.0 & & \\
\hline 0.0 & 0.0 & 0.0 & 0.0 & 0.0 & 0.0 & 0.0 & 0.0 & 4672.4 & 4741.8 & ROW & \\
\hline 4841.3 & 4917.9 & 4972.8 & 5000.8 & 5029.0 & 5196.2 & 5351.4 & 5419.7 & 6089.4 & 7413.5 & & \\
\hline 7051.8 & 5938.7 & 5958.4 & 5959.3 & 6048.3 & 6269.4 & 6371.7 & 6088.1 & 5565.1 & 5507.3 & & \\
\hline 5504.3 & 6137.4 & 5064.9 & 4765.6 & 4510.0 & 4255.0 & 4248.0 & 4212.0 & 4212.0 & 4179.0 & & \\
\hline 4212.0 & 4212.1 & 4241.5 & 4248.5 & 4268.3 & 4303.0 & 4379.8 & 4499.7 & 4731.4 & 5344.5 & & \\
\hline 5185.9 & 5152.9 & 5144.2 & 5130.9 & 5002.6 & 4765.7 & 4477.4 & 4503.7 & 0.0 & 0.0 & & \\
\hline 0.0 & 0.0 & 0.0 & 0.0 & 0.0 & 0.0 & 0.0 & 0.0 & 4656.0 & 4734.2 & ROW & \\
\hline 4801.6 & 4899.1 & 4976.8 & 5096.3 & 5212.7 & 5334.9 & 5369.1 & 5393.5 & 6280.4 & 7843.6 & & \\
\hline 6015.9 & 5890.4 & 5995.2 & 5968.0 & 5954.7 & 6044.6 & 5952.5 & 5814.7 & 5737.8 & 5578.5 & & \\
\hline 5344.1 & 5278.6 & 5697.9 & 5317.6 & 5172.3 & 4969.2 & 4980.4 & 4212.0 & 4212.0 & 4212.0 & & \\
\hline 4212.0 & 4213.0 & 4237.7 & 4256.8 & 4273.6 & 4312.0 & 4381.4 & 4445.0 & 4723.0 & 5174.7 & & \\
\hline 5268.0 & 5231.3 & 5258.4 & 5226.4 & 5124.0 & 4889.9 & 4550.4 & 4507.2 & 0.0 & 0.0 & & \\
\hline 0.0 & 0.0 & 0.0 & 0.0 & 0.0 & 0.0 & 0.0 & 0.0 & 4726.3 & 4747.9 & ROW & \\
\hline 4890.2 & 5067.1 & 5103.2 & 5229.7 & 5715.8 & 5564.8 & 5561.9 & 5568.1 & 5813.5 & 7473.5 & & \\
\hline 5934.6 & 5920.2 & 5952.0 & 5988.8 & 6066.1 & 6230.1 & 6096.6 & 5787.6 & 5793.5 & 5707.6 & & \\
\hline 5316.4 & 5155.7 & 5306.0 & 5271.8 & 5265.5 & 5285.3 & 5325.0 & 4827.7 & 4371.0 & 4212.0 & & \\
\hline 4212.0 & 4235.3 & 4245.3 & 4269.4 & 4287.8 & 4328.4 & 4394.4 & 4464.6 & 4840.4 & 5360.6 & & \\
\hline 5398.9 & 5520.9 & 5657.1 & 6072.1 & 5525.2 & 5223.3 & 5085.7 & 4864.6 & 0.0 & 0.0 & & \\
\hline 0.0 & 0.0 & 0.0 & 0.0 & 0.0 & 0.0 & 0.0 & 0.0 & 4747.2 & 4744.1 & ROW & \\
\hline 5157.3 & 5393.4 & 5176.1 & 5312.1 & 5797.8 & 5690.0 & 5615.0 & 5544.5 & 5875.6 & 6112.4 & & \\
\hline 5952.6 & 5955.9 & 5967.9 & 6336.7 & 6191.4 & 6400.3 & 7120.7 & 6139.9 & 5820.2 & 5655.6 & & \\
\hline 5383.2 & 5229.2 & 5112.2 & 5393.1 & 5383.4 & 5353.2 & 5499.1 & 5128.2 & 4565.0 & 4212.0 & & \\
\hline 4212.0 & 4212.0 & 4212.1 & 4294.0 & 4311.4 & 4336.6 & 4397.7 & 4488.9 & 4588.6 & 5082.1 & & \\
\hline 5141.7 & 5385.2 & 5791.2 & 5571.7 & 5329.2 & 5222.8 & 5278.4 & 5046.2 & 4891.9 & 0.0 & & \\
\hline 0.0 & 0.0 & 0.0 & 0.0 & 0.0 & 0.0 & 0.0 & 0.0 & 4837.7 & 4758.1 & ROW & 17 \\
\hline 5843.5 & 5405.0 & 5296.5 & 5420.6 & 5872.6 & 5758.6 & 5680.4 & 5594.8 & 5898.7 & 6416.2 & & \\
\hline 5952.3 & 5962.4 & 6159.1 & 6500.5 & 6248.9 & 6246.6 & 6659.0 & 6044.8 & 5821.6 & 5859.0 & & \\
\hline 5738.1 & 5758.1 & 5603.4 & 5543.5 & 5549.5 & 5577.5 & 5650.7 & 6254.8 & 4794.3 & 4245.8 & & \\
\hline 4245.1 & 4266.1 & 4242.2 & 4245.4 & 4317.9 & 4364.8 & 4424.5 & 4496.0 & 4568.7 & 4626.9 & & \\
\hline 4665.0 & 4841.2 & 4921.5 & 4934.8 & 4985.4 & 5070.8 & 5158.9 & 5196.1 & 5213.1 & 5366.9 & & \\
\hline 0.0 & 0.0 & 0.0 & 0.0 & 0.0 & 0.0 & 0.0 & 0.0 & 5442.6 & 5702.3 & ROW & 18 \\
\hline 5606.0 & 5480.0 & 5495.2 & 5601.8 & 5770.2 & 5754.3 & 5796.6 & 5706.5 & 5913.6 & 6440.2 & & \\
\hline 5952.7 & 6460.5 & 6468.0 & 6632.2 & 6205.1 & 6293.3 & 6725.2 & 5821.8 & 5826.7 & 6377.6 & & \\
\hline 6149.2 & 6060.8 & 5787.7 & 5680.8 & 5687.2 & 5721.7 & 5771.7 & 5964.7 & 4839.2 & 4353.8 & & \\
\hline 4435.3 & 4389.6 & 4345.4 & 4281.9 & 4336.7 & 4392.2 & 4441.6 & 4506.0 & 4569.7 & 4587.1 & & \\
\hline 4586.3 & 4650.1 & 4761.6 & 4820.3 & 4897.7 & 5033.8 & 5132.7 & 5199.4 & 5216.8 & 5321.0 & & \\
\hline 0.0 & 0.0 & 0.0 & 0.0 & 0.0 & 0.0 & 0.0 & 0.0 & 5590.0 & 5729.2 & ROW & \\
\hline 5731.3 & 5650.0 & 5685.3 & 5813.1 & 5844.8 & 5736.3 & 5833.9 & 5932.4 & 6165.1 & 6355.5 & & \\
\hline 6610.5 & 6498.6 & 6507.2 & 6240.4 & 6243.1 & 6649.4 & 6435.4 & 5953.1 & 5887.0 & 6500.4 & & \\
\hline 6204.2 & 6109.7 & 5819.2 & 5813.9 & 6100.9 & 6329.6 & 6734.4 & 5665.3 & 4594.4 & 4590.0 & & \\
\hline 4531.1 & 4454.8 & 4423.1 & 4399.4 & 4409.5 & 4428.7 & 4445.5 & 4459.6 & 4509.4 & 4560.2 & & \\
\hline 4570.0 & 4610.0 & 4687.6 & 4719.0 & 4784.8 & 4906.6 & 5124.6 & 5139.9 & 5199.8 & 5297.5 & & \\
\hline 0.0 & 0.0 & 0.0 & 0.0 & 0.0 & 0.0 & 0.0 & 0.0 & 5590.1 & 6049.2 & ROW & \\
\hline 6053.8 & 6092.4 & 6461.0 & 6396.3 & 5937.9 & 5754.6 & 5757.2 & 5855.8 & 5787.8 & 6203.7 & & \\
\hline 6377.8 & 6132.2 & 6050.6 & 6508.2 & 6152.1 & 6425.2 & 6439.2 & 6079.3 & 5955.8 & 6081.5 & & \\
\hline 6131.4 & 5968.2 & 5890.8 & 6062.9 & 7054.4 & 5872.0 & 5337.2 & 4858.1 & 4704.2 & 4620.6 & & \\
\hline 4539.8 & 4477.3 & 4434.3 & 4432.3 & 4437.4 & 4439.1 & 4459.4 & 4517.8 & 4541.6 & 4551.0 & & \\
\hline 4555.1 & 4585.0 & 4619.0 & 4613.4 & 4673.2 & 5317.3 & 5401.4 & 5111.8 & 5085.2 & 5093.5 & & \\
\hline 0.0 & 0.0 & 0.0 & 0.0 & 0.0 & 0.0 & 0.0 & 0.0 & 5590.5 & 6077.7 & ROW & \\
\hline 6112.5 & 6190.8 & 6202.2 & 6174.4 & 5990.2 & 5831.8 & 5841.3 & 5915.4 & 5787.6 & 6191.8 & & \\
\hline 6217.8 & 6084.3 & 6256.6 & 6634.0 & 6238.4 & 6215.1 & 6204.1 & 6075.9 & 5984.5 & 6128.7 & & \\
\hline 6454.8 & 5801.1 & 5707.3 & 5914.5 & 6293.5 & 5620.9 & 5059.9 & 4903.2 & 4737.1 & 4633.4 & & \\
\hline 4495.3 & 4436.0 & 4384.2 & 4418.2 & 4468.4 & 4471.8 & 4487.0 & 4518.4 & 1545.0 & 4556.6 & & \\
\hline 4575.9 & 4583.8 & 4599.1 & 4647.1 & 4742.5 & 5278.1 & 5564.5 & 5306.8 & 5176.9 & 5118.1 & & \\
\hline
\end{tabular}


APPENDIX 2. STARTING HEADS USED FOR SIMULATION-Continued

\begin{tabular}{|c|c|c|c|c|c|c|c|c|c|c|c|}
\hline 0.0 & 0.0 & 0.0 & 0.0 & 0.0 & 0.0 & 0.0 & 0.0 & 5659.5 & 6079.9 & ROW & \\
\hline 079.6 & 6070.4 & 6046.2 & 6011.9 & 6002.9 & 5939.7 & 5897.9 & 5975.9 & 5787.6 & 6105.1 & & \\
\hline 133.8 & 6165.1 & 216.6 & 6608.2 & 6266.9 & 6230.8 & 6185.6 & 985.6 & 984.8 & 6100.7 & & \\
\hline 5.2 & 736.1 & 532.9 & 5934.7 & 7066.7 & 6288.5 & 5061.0 & 4772.0 & 757.0 & 4680.3 & & \\
\hline 1.2 & 433.1 & 389.1 & 401.2 & 4466.7 & 494.5 & 511.7 & 4528.7 & 544.4 & 4556.9 & & \\
\hline 59.7 & 4540.2 & 563.1 & 573.1 & 4730.0 & 037.6 & 335.8 & 513.1 & 346.3 & 5186.3 & & \\
\hline 0.0 & 0.0 & 0.0 & 0.0 & 0.0 & 6209.7 & 6097.3 & 5984.7 & 043.1 & 6114.2 & ROW & $\leqslant 2$ \\
\hline 068.1 & 6030.6 & 5016.5 & 5989.7 & 5987.5 & 6038.0 & 6021.5 & 6078.5 & 5787.6 & 5874.6 & & \\
\hline 44.1 & 152.4 & 181.2 & 6258.1 & 504.3 & 769.5 & 5653.3 & 6213.5 & 6083.3 & 6233.9 & & \\
\hline 10.3 & 309.0 & 526.1 & 527.1 & 5783.8 & 628.4 & 382.1 & 4863.1 & 803.8 & 4769.2 & & \\
\hline 561.2 & 547.9 & 4491.7 & 4493.6 & 4535.7 & 539.0 & 1532.2 & 4529.0 & 542.6 & 4555.4 & & \\
\hline 573.0 & 573.0 & 573.1 & 4599.4 & 4574.9 & 923.2 & 5253.2 & 5519.4 & 507.8 & 0.0 & & \\
\hline 0.0 & 0.0 & 0.0 & 0.0 & 0.0 & 6148.5 & 6110.6 & 6091.2 & 6373.3 & 6199.5 & ROW & \\
\hline 104.9 & 6075.7 & 6039.2 & 6036.4 & 6107.9 & 6435.5 & 6515.3 & 6251.4 & 6002.1 & 6000.0 & & \\
\hline 051.3 & 6110.8 & 6366.5 & 6305.6 & 6334.1 & 6431.2 & 6674.8 & 6301.6 & 6156.8 & 6313.1 & & \\
\hline 468.1 & 6364.4 & 5527.4 & 5622.7 & 6847.7 & 6904.1 & 5350.3 & 5021.4 & 36.6 & 4836.5 & & \\
\hline 740.5 & 4637.5 & 4566.9 & 4569.2 & 4605.6 & 4588.1 & 4535.1 & 4475.1 & 27.7 & 4547.6 & & \\
\hline 616.2 & 4583.8 & 4637.7 & 4652.3 & 4618.1 & 5030.2 & 5387.5 & 5669.0 & 5657.1 & 0.0 & & \\
\hline 0.0 & 0.0 & 0.0 & 0.0 & 0.0 & 5900.2 & 5812.4 & 5851.6 & 6165.9 & 6416.4 & ROW & \\
\hline 424.2 & 6241.2 & 6112.4 & 6072.8 & 6099.4 & 6151.0 & 6026.3 & 5954.6 & 5979.2 & 5991.2 & & \\
\hline 033.4 & 6127.6 & 6533.4 & 6297.5 & 6258.2 & 6255.8 & 6368.0 & 6374.7 & 6377.1 & 6401.2 & & \\
\hline 827.8 & 6500.3 & 5721.0 & 5654.4 & 6299.0 & 5994.7 & 5638.5 & 5103.4 & 4941.7 & 4923.4 & & \\
\hline 4849.4 & 4785.1 & 4686.3 & 4634.3 & 4645.1 & 4648.6 & 4525.6 & 4521.7 & 4621.8 & 4698.1 & & \\
\hline 723.5 & 4732.1 & 4757.1 & 4774.7 & 4676.3 & 5256.1 & 5701.9 & 5932.0 & 0.0 & 0.0 & & \\
\hline 0.0 & 0.0 & 0.0 & 0.0 & 0.0 & 5652.9 & 5635.8 & 5633.4 & 6109.2 & 6471.2 & ROW & \\
\hline 508.8 & 6495.5 & 6317.0 & 6091.6 & 6102.2 & 6056.4 & 6040.0 & 6054.0 & 6168.7 & 5911.8 & & \\
\hline 5920.7 & 5947.4 & 6413.8 & 6386.5 & 6202.0 & 6141.3 & 6105.5 & 6112.3 & 6413.0 & 6495.0 & & \\
\hline 6526.7 & 6467.0 & 5806.6 & 5788.4 & 5903.9 & 6317.4 & 5423.0 & 5106.6 & 4974.5 & 4953.4 & & \\
\hline 929.8 & 4913.0 & 4799.8 & 4697.1 & 4669.8 & 4663.3 & 4562.1 & 31.8 & 4605.6 & 4772.3 & & \\
\hline 866.6 & 4896.1 & 4944.1 & 5043.4 & 5373.6 & 5786.9 & 6024.7 & 6163.0 & 0.0 & 0.0 & & \\
\hline 0.0 & 0.0 & 0.0 & 0.0 & 5576.4 & 5564.4 & 5522.0 & 5580.9 & 6697.0 & 6576.2 & ROW & \\
\hline 585.1 & 6603.9 & 7193.1 & 6164.5 & 6176.8 & 6158.9 & 6140.7 & 6138.7 & 6442.4 & 5777.3 & & \\
\hline 767.6 & 5776.9 & 5811.1 & 6369.9 & 6214.7 & 6094.4 & 6006.2 & 5900.4 & 6709.0 & 6863.4 & & \\
\hline 6576.6 & 6519.5 & 5814.9 & 5788.8 & 5847.8 & 6443.9 & 5588.8 & 5375.9 & 5277.7 & 5203.5 & & \\
\hline 5038.3 & 4866.5 & 4821.2 & 4727.2 & 4709.5 & 4704.8 & 4656.2 & 4556.3 & 4731.5 & 4879.2 & & \\
\hline 947.5 & 5015.5 & 5319.4 & 5680.8 & 5888.6 & 6152.1 & 0.0 & 0.0 & 0.0 & 0.0 & & \\
\hline 0.0 & 0.0 & 0.0 & 0.0 & 5528.9 & 5461.4 & 5459.3 & 6344.8 & 6634.6 & 6612.4 & ROW & \\
\hline 595.9 & 6641.2 & 6798.1 & 6492.3 & 6415.3 & 6666.7 & 6162.2 & 45.7 & 6311.1 & 5631.2 & & \\
\hline 551.8 & 5547.3 & 5608.1 & 6312.5 & 6455.0 & 6003.2 & 5834.6 & 5578.6 & 6536.8 & 6829.2 & & \\
\hline 6542.8 & 6350.9 & 6002.6 & 5788.2 & 5788.3 & 6839.5 & 6894.5 & 03.7 & 23.4 & 5477.9 & & \\
\hline 5240.8 & 4884.2 & 4851.2 & 4788.1 & 4761.0 & 57.3 & 4756.2 & 5102.1 & 4959.9 & 4901.6 & & \\
\hline 899.7 & 5157.8 & 5608.5 & 6010.3 & 6280.3 & 44.5 & 0.0 & 0.0 & 0.0 & 0.0 & & \\
\hline 0.0 & 0.0 & 0.0 & 0.0 & 5557.3 & 02.0 & 5545.3 & 70.0 & 53.4 & 6647.4 & ROW & \\
\hline 640.5 & 6683.2 & 6775.8 & 6396.2 & 6524.1 & 14.1 & 6230.0 & 19.3 & 13.2 & 5508.0 & & \\
\hline 163.9 & 4976.7 & 5247.8 & 5932.1 & 6243.6 & 320.5 & 5620.7 & 5357.5 & 5884.6 & 6179.7 & & \\
\hline 443.2 & 6427.9 & 6025.9 & 5867.9 & 5858.0 & 46.9 & 5882.6 & 5692.5 & 5555.0 & 5680.0 & & \\
\hline 561.0 & 206.4 & 4946.0 & 4871.4 & 4814.4 & 308.2 & 4959.5 & 5487.9 & 5072.5 & 5034.1 & & \\
\hline 044.6 & 244.0 & 6546.8 & 6651.2 & 01.1 & 84.4 & 7216.3 & 0. & 0.0 & 0.0 & & \\
\hline 0.0 & 0.0 & 0.0 & 0.0 & 60.6 & 27.6 & 5586.2 & 6708.7 & 6.9 & 6692.0 & ROW & \\
\hline 703.9 & 6756.1 & 476.8 & 190.5 & 5.6 & 9.1 & 39.7 & 4.6 & 3.4 & 5694.2 & & \\
\hline 966.9 & 1.3 & 4839.8 & 2.3 & 24.2 & 2.1 & 78.5 & 95.3 & 6.7 & 79.2 & & \\
\hline 109.7 & 2.1 & 912.9 & 3.9 & 06.4 & 1.4 & 5845 . & 23.9 & 93.5 & 5940.0 & & \\
\hline 2.4 & 9.4 & 29.2 & 7.4 & 6.8 & 8.9 & 50 & 68.1 & 5101.3 & 5052.7 & & \\
\hline 49.0 & 43.8 & 439.9 & 000.5 & 9. & 4.1 & 1. & 39.5 & 0.0 & 0.0 & & \\
\hline 0.0 & 0.0 & 0.0 & 0.0 & 83.5 & 3.8 & 56 & 73.5 & 39 & 6726.2 & ROW & \\
\hline 32.4 & 6753.4 & 444.3 & 124.0 & 8.9 & 1.8 & 62 & 38.5 & 3.4 & 5203.5 & & \\
\hline & 24.7 & 705.3 & 2.2 & 4.8 & 9.2 & 88. & 36.2 & 5.5 & 5781.1 & & \\
\hline 4.3 & 2.7 & 950.8 & 5.3 & 58.8 & 1.1 & 6060. & 04.8 & 5973.1 & 6144.9 & & \\
\hline 05.0 & 6022.3 & 717.4 & 5625.7 & 42.3 & 0.2 & 92. & 05.1 & 5035.3 & 4967.8 & & \\
\hline 66.6 & 84.9 & 613.7 & 186.6 & 51.8 & 24.6 & 7.7 & 06.6 & 0.0 & 0.0 & & \\
\hline 0.0 & 0.0 & 0.0 & 0.0 & 10.5 & 77.1 & 5680.2 & 6770.7 & 6756.2 & 6741.6 & ROW & \\
\hline 43.6 & 58.9 & 98.7 & 29.8 & 36.1 & 42.4 & 5654.4 & 5455.3 & 64.4 & 5414.0 & & \\
\hline 4723.3 & 4645.2 & 4672.3 & 4986.2 & 5128.6 & 5176.2 & 5262.5 & 95.0 & 5164.3 & 5545.1 & & \\
\hline 5524.8 & 5780.8 & 6094.7 & 5912.2 & 6052.0 & 6311.0 & 6655.0 & 6377.0 & 6288.0 & 6307.7 & & \\
\hline 6377.9 & 6703.9 & 6331.1 & 6406.4 & 6872.1 & 5872.0 & 57.57 .2 & 502.4 .8 & 5003.2 & 4990.3 & & \\
\hline 032.3 & 5322.6 & 5739.1 & 6267.6 & 6228.5 & 6652.0 & 6907.5 & 6991.9 & 0.0 & 0.0 & & \\
\hline
\end{tabular}




\section{APPENDIX 2. STARTING HEADS USED FOR SIMULATION-Continued}

\begin{tabular}{|c|c|c|c|c|c|c|c|c|c|c|c|}
\hline 0.0 & 0.0 & 0.0 & 0.0 & 6100.9 & 5645.1 & 5669.3 & 6703.8 & 6784.6 & 6773.0 & ROW & 73 \\
\hline 6799.8 & 6721.3 & 6310.5 & 5849.9 & 5681.3 & 5508.1 & 5466.6 & 5371.9 & 5321.4 & 5390.3 & & \\
\hline 666.9 & 4650.9 & 4672.9 & 4844.2 & 5051.3 & 112.5 & 5181.4 & 139.8 & 5169.1 & 5200.1 & & \\
\hline 322.9 & 5636.5 & 5669.6 & 5889.4 & 6077.1 & 867.2 & 7026.6 & 6234.1 & 6381.0 & 6586.2 & & \\
\hline 498.1 & 6792.5 & 6886.5 & 6403.2 & 6272.0 & 007.9 & 5353.9 & 032.3 & 5052.5 & 5159.3 & & \\
\hline 274.1 & 5460.2 & 5654.2 & 5783.6 & 5729.0 & 398.2 & 6705.6 & 0.0 & 0.0 & 0.0 & & \\
\hline 0.0 & 0.0 & 0.0 & 5489.9 & 303.3 & 387.2 & 5559.8 & 5931.7 & 6245.6 & 6707.0 & ROW & \\
\hline 7291.0 & 6117.0 & 5968.2 & 5890.2 & 5480.2 & 357.7 & 5323.7 & 270.2 & 5118.0 & 4930.4 & & \\
\hline 739.5 & 4711.9 & 4828.3 & 4941.0 & 5293.7 & 083.6 & 5047.8 & 1989.6 & 4952.9 & 4917.3 & & \\
\hline 901.9 & 5117.9 & 5266.6 & 5623.0 & 5881.3 & 923.3 & 6194.8 & 155.2 & 6155.4 & 6299.8 & & \\
\hline 451.5 & 6401.0 & 6346.4 & 6582.5 & 5751.8 & 469.0 & 5052.1 & 5090.2 & 5150.1 & 5339.3 & & \\
\hline 412.8 & 5515.6 & 5675.1 & 5763.3 & 6186.5 & 6456.1 & 0.0 & 0.0 & 0.0 & 0.0 & & \\
\hline 0.0 & 0.0 & 5223.1 & 5112.0 & 5155.1 & 234.5 & 5355.5 & 5416.6 & 5489.3 & 5758.7 & ROW & \\
\hline 205.6 & 5688.2 & 5679.2 & 6307.0 & 5433.6 & 5272.6 & 5164.5 & 092.3 & 4999.5 & 4868.5 & & \\
\hline 336.7 & 4967.0 & 5122.5 & 5156.7 & 5088.0 & 5005.7 & 4923.4 & 1868. & 4845.5 & 4810.6 & & \\
\hline 61.1 & 4850.4 & 4840.9 & 5393.6 & 6166.9 & 5705.2 & 5775.3 & 840. & 5812.4 & 5913.3 & & \\
\hline 245.9 & 5981.8 & 5951.7 & 5497.8 & 5288.2 & 5197.1 & 5065.4 & 133. & 5187.4 & 5303.6 & & \\
\hline 371.8 & 5395.7 & 5835.9 & 6216.5 & 6486.5 & 6628.7 & 0.0 & 0 . & 0.0 & 0.0 & & \\
\hline 530.7 & 4652.1 & 4675.7 & 4731.7 & 4837.1 & 4968.9 & 5931.3 & 5377. & 5397.2 & 5902.5 & ROW & \\
\hline 621.3 & 5597.4 & 5590.3 & 5493.1 & 5379.2 & 5315.2 & 0.8 & 5 . & 5024.1 & 5051.0 & & \\
\hline 308.5 & 6024.9 & 5921.2 & 5220.0 & & 4856.4 & 4804.3 & 1774.1 & 4745.8 & 4682.3 & & \\
\hline 598.6 & 4793.6 & 4813.4 & 4880.6 & & 5341.8 & 5193.1 & 209.4 & 5436.6 & 5525.4 & & \\
\hline 562.7 & 6164.2 & 5387.9 & 5186.5 & & 5131.1 & 5132.5 & 5238. & 5318.1 & 5374.0 & & \\
\hline 427.0 & 5726.0 & 6134.9 & 6423.9 & 6590.2 & 0.0 & 0.0 & & 0.0 & 0.0 & & \\
\hline 582.5 & 4585.8 & 4583.1 & 4589.0 & & 4813.8 & 5263.2 & 5261. & 5255.2 & 5283.4 & ROW & \\
\hline 472.5 & 5517.1 & 5514.9 & 5507.1 & & 77.6 & & & 5043.0 & 4832.4 & & \\
\hline 165.9 & 5566.0 & 5133.1 & 31.5 & & 72.9 & & & 4626.6 & 4559.7 & & \\
\hline 532.8 & 4711.2 & 4615.1 & 4658.7 & & 29.1 & & 478 & 5031.6 & 5154.4 & & \\
\hline 5255.2 & 5304.9 & 5311.6 & 5282.8 & 5243.0 & 131.4 & 383.1 & & 5492.2 & 5457.0 & & \\
\hline 5460.4 & 5814.1 & 6210.9 & 6424.4 & 0.0 & 0.0 & 0.0 & & 0.0 & 0.0 & & \\
\hline 320 & 4514.3 & 4514.1 & 4523.6 & 4544.2 & 4595.0 & 5033.4 & & 5160.4 & 5175.2 & ROW & \\
\hline 319.1 & 5455.3 & 5466.1 & 5478.6 & 19.6 & 5389.2 & 526 & & 5049.3 & 4986.4 & & \\
\hline 9.5 & 4902.6 & 4869.0 & 4818.9 & 4758.4 & 7.6 & 2.4 & & 78.5 & 4456.1 & & \\
\hline & 4433.7 & 45.4 & 4485.5 & 4538. & 4581.4 & 458 & & 4704.7 & 4886.4 & & \\
\hline & 5190.6 & 5326.7 & 5378.3 & & 5463.4 & 5575.1 & 5788. & 5864.2 & 0.0 & & \\
\hline 0.0 & 0.0 & 0.0 & 0.0 & & 0.0 & 0.0 & & 0.0 & 0.0 & & \\
\hline 1792 & 476.8 & 179.5 & 470.0 & & 31.2 & 4764.1 & 1 & 7.4 & 5152.3 & ROW & \\
\hline & 51.6 & 2.6 & & & 5.3 & & & 9.3 & 4954.2 & & \\
\hline & 3.0 & 1.2 & & & & & & 42.6 & & & \\
\hline & 9.0 & 5.9 & 7.1 & & 9.9 & & & 617.0 & 722.5 & & \\
\hline 97.0 & 119.2 & 11.6 & 423.6 & 16.6 & 5581.8 & 707.0 & & 0.0 & 0.0 & & \\
\hline & 0.0 & 0.0 & 0.0 & & 0.0 & 0.0 & & 0.0 & 0.0 & & \\
\hline 4436.4 & 417.5 & 09.6 & 386.8 & & 8.7 & 4619.7 & & 5077.7 & 5142.4 & ROW & \\
\hline & 8.4 & .6 & 1.9 & & 8.8 & 7.2 & 7 & 7.6 & 7.4 & & \\
\hline & 4.6 & .4 & 1.6 & & 5.6 & & & 5.1 & 4.1 & & \\
\hline & 1.4 & & 4.2 & 39. & 07.8 & 257.0 & 78. & 24.9 & 34.1 & & \\
\hline & 53.3 & 4 & 90.4 & & & 0.0 & & 0.0 & 0.0 & & \\
\hline 0. & 0.0 & & 0.0 & & & & & 0. & 0.0 & & \\
\hline 4406 . & 4327.1 & & 280 . & & & 4705.2 & 516 & 4.9 & 74.6 & ROW & \\
\hline & & & & & & & & & 2.5 & & \\
\hline & & & 7.0 & & 7.5 & & & 6.6 & 7.4 & & \\
\hline & .8 & .0 & 5.8 & & 69.4 & 52.8 & 37 & 05.9 & 84.4 & & \\
\hline 50 & 139.7 & 57.4 & 79.7 & 0. & 0.0 & 0.0 & & 0.0 & 0.0 & & \\
\hline 0.0 & 0.0 & 0.0 & 0.0 & 0. & 0.0 & 0.0 & c & 0.0 & 0.0 & & \\
\hline & 302.6 & 78.5 & 84.0 & 97. & 55.8 & 42.0 & & 07.8 & 58.2 & ROW & \\
\hline & 4.1 & 3.7 & 7.1 & & 2.8 & 8.2 & & 2.7 & 0.0 & & \\
\hline & 5.2 & 9.5 & 1.0 & & & .9 & 37 & 47.7 & 9.1 & & \\
\hline 4.3 & 1.5 & 3.4 & 9.0 & 47.5 & 66.1 & 3449.4 & 32 & 396.0 & 3498.0 & & \\
\hline 3512.1 & 3508.4 & 41.2 & 3670.0 & 0.0 & 0.0 & 0.0 & & 0.0 & 0.0 & & \\
\hline 0.0 & 0.0 & 0.0 & 0.0 & 0. & 0. & 0.0 & 0 & 0.0 & 0.0 & & \\
\hline 76.4 & 804.0 & 36.0 & 73.4 & 13.3 & 33.7 & 53.6 & 76 & 58.6 & 4555.2 & ROW & \\
\hline & 4543.8 & 3.1 & 4745.7 & 25.0 & 33.0 & 4916.0 & & 4960.2 & 5086.3 & & \\
\hline 4834.3 & 4613.7 & 4254.0 & 3869.8 & 3768.5 & 41.1 & 3568.1 & 350 & 3449.6 & 3337.6 & & \\
\hline 3244.7 & 3234.9 & $3370: 2$ & 4007.0 & 01.5 & 63.1 & 2980.4 & 2847.9 & 2928.6 & 3009.2 & & \\
\hline 3071.2 & 3040.6 & 2906.2 & 3093.6 & 10.3 & 0.0 & 0.0 & & 0.0 & 0.0 & & \\
\hline 0.0 & 0.0 & 0.0 & 0.0 & 0.0 & 0.0 & 0.0 & 0.0 & 0.0 & 0.0 & & \\
\hline
\end{tabular}




\section{APPENDIX 2. STARTING HEADS USED FOR SIMULATION-Continued}

\begin{tabular}{|c|c|c|c|c|c|c|c|c|c|c|c|}
\hline 0.0 & 0.0 & 0.0 & 5167.5 & 4498.1 & 4395.9 & 4317.3 & 4252.6 & 4189.1 & 4201.2 & ROW & 44 \\
\hline 4350.2 & 4447.4 & 4568.0 & 4742.5 & 4810.4 & 4856.8 & 4861.5 & 4853.9 & 4796.2 & 4615.4 & & \\
\hline 4386.8 & 4246.1 & 3813.2 & 3570.5 & 3514.8 & 3441.8 & 3422.1 & 3387.9 & 3301.2 & 3151.5 & & \\
\hline 3008.0 & 2854.9 & 2682.1 & 2720.3 & 2670.9 & 2735.6 & 2618.7 & 2756.0 & 2644.4 & 2634.8 & & \\
\hline 2445.0 & 2396.8 & 2361.8 & 2399.0 & 2523.8 & 0.0 & 0.0 & 0.0 & 0.0 & 0.0 & & \\
\hline 0.0 & 0.0 & 0.0 & 0.0 & 0.0 & 0.0 & 0.0 & 0.0 & 0.0 & 0.0 & & \\
\hline 0.0 & 0.0 & 0.0 & 4299.7 & 4270.4 & 4405.8 & 4990.6 & 4198.5 & 4038.6 & 3950.1 & ROW & 45 \\
\hline 4103.5 & 4221.3 & 4319.8 & 4418.5 & 4564.6 & 4569.5 & 4519.3 & 4509.8 & 4625.6 & 4183.9 & & \\
\hline 3429.7 & 3059.9 & 3176.2 & 3191.2 & 3311.4 & 3456.3 & 3621.4 & 3409.3 & 3064.0 & 2870.8 & & \\
\hline 2791.3 & 2533.1 & 2221.3 & 2217.3 & 2394.6 & 2213.7 & 2188.3 & 2322.5 & 2302.2 & 2191.8 & & \\
\hline 2120.6 & 2062.0 & 1902.9 & 1853.6 & 1747.2 & 0.0 & 0.0 & 0.0 & 0.0 & 0.0 & & \\
\hline 0.0 & 0.0 & 0.0 & 0.0 & 0.0 & 0.0 & 0.0 & 0.0 & 0.0 & 0.0 & & \\
\hline 0.0 & 0.0 & 0.0 & 3825.0 & 3642.0 & 3574.7 & 3904.9 & 3568.5 & 3688.3 & 3814.7 & ROW & 46 \\
\hline 3876.3 & 3969.9 & 4072.0 & 4073.8 & 4161.0 & 4185.5 & 4103.5 & 4081.8 & 4008.5 & 3711.9 & & \\
\hline 2894.2 & 2864.9 & 2976.8 & 2934.7 & 3027.9 & 3056.1 & 3049.3 & 3028.1 & 3022.4 & 2829.4 & & \\
\hline 2743.0 & 2510.9 & 2199.3 & 2184.3 & 2146.1 & 2118.5 & 2125.5 & 2115.7 & 2116.2 & 2055.6 & & \\
\hline 2011.7 & 1878.4 & 1687.5 & 1668.4 & 0.0 & 0.0 & 0.0 & 0.0 & 0.0 & 0.0 & & \\
\hline 0.0 & 0.0 & 0.0 & 0.0 & 0.0 & 0.0 & 0.0 & 0.0 & 0.0 & 0.0 & & \\
\hline 0.0 & 0.0 & 0.0 & 0.0 & 3107.3 & 3042.5 & 2998.8 & 3146.7 & 3913.6 & 3696.7 & ROW & 47 \\
\hline 3593.2 & 3701.0 & 4081.3 & 3510.1 & 3488.2 & 3611.4 & 3607.8 & 3525.6 & 3614.7 & 3078.1 & & \\
\hline 2777.1 & 2768.7 & 2794.8 & 2883.8 & 3185.9 & 2922.0 & 2866.2 & 2861.7 & 3201.3 & 2904.7 & & \\
\hline 2525.1 & 2458.7 & 2188.4 & 2160.1 & 2086.7 & 1997.7 & 1892.5 & 1876.5 & 1896.5 & 1854.7 & & \\
\hline 1752.0 & 1635.8 & 0.0 & 0.0 & 0.0 & 0.0 & 0.0 & 0.0 & 0.0 & 0.0 & & \\
\hline 0.0 & 0.0 & 0.0 & 0.0 & 0.0 & 0.0 & 0.0 & 0.0 & 0.0 & 0.0 & & \\
\hline 0.0 & 0.0 & 0.0 & 0.0 & 0.0 & 2742.1 & 2458.0 & 2350.0 & 2549.0 & 2981.4 & ROW & 48 \\
\hline 2796.2 & 2886.5 & 3041.4 & 3094.2 & 3163.5 & 2965.1 & 2882.1 & 2746.0 & 2633.7 & 2637.2 & & \\
\hline 2663.1 & 2688.2 & 2717.9 & 2747.5 & 2835.6 & 2848.7 & 2854.6 & 2864.6 & 2880.4 & 2849.0 & & \\
\hline 2757.8 & 3214.4 & 2717.9 & 2050.6 & 1930.1 & 1815.9 & 1598.5 & 1588.7 & 1633.8 & 1562.6 & & \\
\hline 1489.2 & 0.0 & 0.0 & 0.0 & 0.0 & 0.0 & 0.0 & 0.0 & 0.0 & 0.0 & & \\
\hline 0.0 & 0.0 & 0.0 & 0.0 & 0.0 & 0.0 & 0.0 & 0.0 & 0.0 & 0.0 & & \\
\hline 0.0 & 0.0 & 0.0 & 0.0 & 0.0 & 0.0 & 0.0 & 1716.0 & 1533.2 & 1529.6 & ROW & 49 \\
\hline 1480.2 & 1586.5 & 1970.7 & 2371.5 & 2461.4 & 2470.7 & 2537.6 & 2543.2 & 2558.8 & 2574.7 & & \\
\hline 2627.5 & 2677.3 & 2727.0 & 2798.4 & 2835.1 & 2841.0 & 2847.0 & 2856.2 & 2869.1 & 2918.2 & & \\
\hline 3073.0 & 3011.2 & 2463.0 & 2043.4 & 1956.9 & 1862.2 & 1736.3 & 1654.8 & 1595.3 & 1223.4 & & \\
\hline 1271.9 & 0.0 & 0.0 & 0.0 & 0.0 & 0.0 & 0.0 & 0.0 & 0.0 & 0.0 & & \\
\hline 0.0 & 0.0 & 0.0 & 0.0 & 0.0 & 0.0 & 0.0 & 0.0 & 0.0 & 0.0 & & \\
\hline 0.0 & 0.0 & 0.0 & 0.0 & 0.0 & 0.0 & 0.0 & 0.0 & 0.0 & 24.0 & ROW & 50 \\
\hline 227.7 & 445.6 & 847.7 & 1481.7 & 1902.9 & 2227.6 & 2410.7 & 2455.3 & 2473.7 & 2517.9 & & \\
\hline 2548.3 & 2604.1 & 2755.5 & 2906.3 & 2960.2 & 2997.8 & 2987.6 & 2880.7 & 2811.7 & 2749.0 & & \\
\hline 2707.4 & 2562.9 & 2639.5 & 2055.8 & 1963.4 & 1931.9 & 1891.3 & 2049.0 & 1650.9 & 1345.0 & & \\
\hline 1229.9 & 0.0 & 0.0 & 0.0 & 0.0 & 0.0 & 0.0 & 0.0 & 0.0 & 0.0 & & \\
\hline 0.0 & 0.0 & 0.0 & 0.0 & 0.0 & 0.0 & 0.0 & 0.0 & 0.0 & 0.0 & & \\
\hline 0.0 & 0.0 & 0.0 & 0.0 & 0.0 & 0.0 & 0.0 & 0.0 & 0.0 & 0.0 & ROW & 51 \\
\hline-143.4 & -132.0 & 118.2 & 826.9 & 1426.2 & 1917.7 & 2155.2 & 2273.0 & 2314.3 & 2377.4 & & \\
\hline 2477.3 & 2617.1 & 2834.6 & 3068.0 & 3246.1 & 3301.2 & 3322.2 & 3070.9 & 2755.1 & 2650.1 & & \\
\hline 2524.9 & 2396.8 & 2305.9 & 2175.7 & 2036.8 & 1961.7 & 1920.0 & 1907.9 & 1775.3 & 1492.1 & & \\
\hline 1221.2 & 0.0 & 0.0 & 0.0 & 0.0 & 0.0 & 0.0 & 0.0 & 0.0 & 0.0 & & \\
\hline 0.0 & 0.0 & 0.0 & 0.0 & 0.0 & 0.0 & 0.0 & 0.0 & 0.0 & 0.0 & & \\
\hline 0.0 & 0.0 & 0.0 & 0.0 & 0.0 & 0.0 & 0.0 & 0.0 & 0.0 & 0.0 & ROW & \\
\hline 0.0 & 0.0 & -182.5 & 186.1 & 834.9 & 1499.4 & 1927.6 & 2118.6 & 2139.2 & 2136.7 & & \\
\hline 2331.2 & 2461.7 & 2801.4 & 3147.9 & 3341.7 & 3463.2 & 3562.9 & 3611.5 & 2844.5 & 2672.4 & & \\
\hline 2494.3 & 2308.4 & 2124.1 & 1975.6 & 1915.6 & 1779.6 & 1650.3 & 1519.2 & 1235.7 & 1211.5 & & \\
\hline 1204.9 & 0.0 & 0.0 & 0.0 & 0.0 & 0.0 & 0.0 & 0.0 & 0.0 & 0.0 & & \\
\hline 0.0 & 0.0 & 0.0 & 0.0 & 0.0 & 0.0 & 0.0 & 0.0 & 0.0 & 0.0 & & \\
\hline 0.0 & 0.0 & 0.0 & 0.0 & 0.0 & 0.0 & 0.0 & 0.0 & 0.0 & 0.0 & ROW & 53 \\
\hline 0.0 & 0.0 & -200.0 & -228.0 & 184.9 & 952.9 & 1562.3 & 1808.9 & 1977.9 & 2087.2 & & \\
\hline 2228.4 & 2434.9 & 2762.0 & 2944.2 & 3083.3 & 3282.2 & 3477.7 & 3964.4 & 3652.7 & 2698.4 & & \\
\hline 2473.6 & 2209.9 & 1889.7 & 1749.1 & 1653.7 & 1454.7 & 1202.4 & 1200.0 & 0.0 & 0.0 & & \\
\hline 0.0 & 0.0 & 0.0 & 0.0 & 0.0 & 0.0 & 0.0 & 0.0 & 0.0 & 0.0 & & \\
\hline 0.0 & 0.0 & 0.0 & 0.0 & 0.0 & 0.0 & 0.0 & 0.0 & 0.0 & 0.0 & & \\
\hline 0.0 & 0.0 & 0.0 & 0.0 & 0.0 & 0.0 & 0.0 & 0.0 & 0.0 & 0.0 & ROW & 54 \\
\hline 0.0 & 0.0 & 0.0 & -258.4 & 38.1 & 269.7 & 958.7 & 1358.4 & 1638.7 & 1814.7 & & \\
\hline 1898.2 & 2063.3 & 2344.6 & 2506.9 & 2693.5 & 2910.3 & 3045.7 & 3297.0 & 3496.5 & 2825.8 & & \\
\hline 2530.1 & 2227.2 & 1907.7 & 1702.8 & 1558.8 & 1504.1 & 1353.3 & 1105.7 & 0.0 & 0.0 & & \\
\hline 0.0 & 0.0 & 0.0 & 0.0 & 0.0 & 0.0 & 0.0 & 0.0 & 0.0 & 0.0 & & \\
\hline 0.0 & 0.0 & 0.0 & 0.0 & 0.0 & 0.0 & 0.0 & 0.0 & 0.0 & 0.0 & & \\
\hline
\end{tabular}




\begin{tabular}{|c|c|c|c|c|c|c|c|c|c|c|}
\hline 0.0 & 0.0 & 0.0 & 0.0 & 0.0 & 0.0 & 0.0 & 0.0 & 0.0 & 0.0 & ROW 55 \\
\hline 0.0 & 0.0 & 0.0 & 0.0 & -225.8 & 250.8 & 840.3 & 1275.8 & 1444.1 & 1646.0 & \\
\hline 1735.4 & 1861.5 & 2100.3 & 2344.3 & 2536.2 & 2722.6 & 2837.3 & 3002.6 & 3257.2 & 3596.0 & \\
\hline 883.8 & 2464.0 & 2182.1 & 1960.7 & 1740.9 & 1579.2 & 1549.9 & 1471.0 & 0.0 & 0.0 & \\
\hline 0.0 & 0.0 & 0.0 & 0.0 & 0.0 & 0.0 & 0.0 & 0.0 & 0.0 & 0.0 & \\
\hline 0.0 & 0.0 & 0.0 & 0.0 & 0.0 & 0.0 & 0.0 & 0.0 & 0.0 & 0.0 & \\
\hline 0.0 & 0.0 & 0.0 & 0.0 & 0.0 & 0.0 & 0.0 & 0.0 & 0.0 & 0.0 & ROW 56 \\
\hline 0.0 & 0.0 & 0.0 & 0.0 & 0.0 & -71.3 & 93.5 & 603.6 & 1023.0 & 1333.3 & \\
\hline 1453.8 & 1560.8 & 1778.7 & 2101.0 & 2352.5 & 2557.9 & 2706.3 & 2809.5 & 2906.0 & 2998.5 & \\
\hline 2994.4 & 2567.0 & 2514.6 & 2337.3 & 1740.3 & 1648.6 & 1627.1 & 1573.7 & 0.0 & 0.0 & \\
\hline 0.0 & 0.0 & 0.0 & 0.0 & 0.0 & 0.0 & 0.0 & 0.0 & 0.0 & 0.0 & \\
\hline 0.0 & 0.0 & 0.0 & 0.0 & 0.0 & 0.0 & 0.0 & 0.0 & 0.0 & 0.0 & \\
\hline 0.0 & 0.0 & 0.0 & 0.0 & 0.0 & 0.0 & 0.0 & 0.0 & 0.0 & 0.0 & ROW \\
\hline 0.0 & 0.0 & 0.0 & 0.0 & 0.0 & -0.5 & 3.9 & 274.2 & 628.6 & 1059.2 & \\
\hline 1380.5 & 1391.5 & 1474.7 & 1776.2 & 2150.9 & 2406.4 & 2562.5 & 2621.2 & 2572.1 & 2652.6 & \\
\hline 2626.7 & 2591.5 & 2561.2 & 2569.2 & 1986.9 & 1677.9 & 1728.1 & 0.0 & 0.0 & 0.0 & \\
\hline 0.0 & 0.0 & 0.0 & 0.0 & 0.0 & 0.0 & 0.0 & 0.0 & 0.0 & 0.0 & \\
\hline 0.0 & 0.0 & 0.0 & 0.0 & 0.0 & 0.0 & 0.0 & 0.0 & 0.0 & 0.0 & \\
\hline 0.0 & 0.0 & 0.0 & 0.0 & 0.0 & 0.0 & 0.0 & 0.0 & 0.0 & 0.0 & ROW \\
\hline 0.0 & 0.0 & 0.0 & 0.0 & 0.0 & 0.0 & 10.6 & 17.5 & 195.6 & 609.5 & \\
\hline 1049.6 & 1326.0 & 1422.6 & 1743.0 & 2397.7 & 2745.1 & 2909.1 & 2825.7 & 2572.1 & 2586.3 & \\
\hline 2592.9 & 2605.3 & 2562.3 & 2421.3 & 2150.4 & 1938.3 & 1884.3 & 0.0 & 0.0 & 0.0 & \\
\hline 0.0 & 0.0 & 0.0 & 0.0 & 0.0 & 0.0 & 0.0 & 0.0 & 0.0 & 0.0 & \\
\hline 0.0 & 0.0 & 0.0 & 0.0 & 0.0 & 0.0 & 0.0 & 0.0 & 0.0 & 0.0 & \\
\hline 0.0 & 0.0 & 0.0 & 0.0 & 0.0 & 0.0 & 0.0 & 0.0 & 0.0 & 0.0 & ROW 59 \\
\hline 0.0 & 0.0 & 0.0 & 0.0 & 0.0 & 0.0 & 0.0 & 0.0 & 454.0 & 436.0 & \\
\hline 505.0 & 654.0 & 879.0 & 1378.3 & 1843.2 & 2211.7 & 2475.6 & 2645.2 & 2723.8 & 2721.8 & \\
\hline 2698.2 & 2690.1 & 2692.6 & 2641.6 & 0.0 & 0.0 & 0.0 & 0.0 & 0.0 & 0.0 & \\
\hline 0.0 & 0.0 & 0.0 & 0.0 & 0.0 & 0.0 & 0.0 & 0.0 & 0.0 & 0.0 & \\
\hline 0.0 & 0.0 & 0.0 & 0.0 & 0.0 & 0.0 & 0.0 & 0.0 & 0.0 & 0.0 & \\
\hline 0.0 & 0.0 & 0.0 & 0.0 & 0.0 & 0.0 & 0.0 & 0.0 & 0.0 & 0.0 & ROW 60 \\
\hline 0.0 & 0.0 & 0.0 & 0.0 & 0.0 & 0.0 & 0.0 & 0.0 & 676.2 & 701.1 & \\
\hline 753.1 & 827.7 & 913.0 & 1062.2 & 1518.0 & 1993.7 & 2348.8 & 2657.3 & 2835.3 & 2913.6 & \\
\hline 2841.9 & 2762.0 & 2733.7 & 2712.2 & 0.0 & 0.0 & 0.0 & 0.0 & 0.0 & 0.0 & \\
\hline 0.0 & 0.0 & 0.0 & 0.0 & 0.0 & 0.0 & 0.0 & 0.0 & 0.0 & 0.0 & \\
\hline 0.0 & 0.0 & 0.0 & 0.0 & 0.0 & 0.0 & 0.0 & 0.0 & 0.0 & 0.0 & \\
\hline 0.0 & 0.0 & 0.0 & 0.0 & 0.0 & 0.0 & 0.0 & 0.0 & 0.0 & 0.0 & ROW 61 \\
\hline 0.0 & 0.0 & 0.0 & 0.0 & 0.0 & 0.0 & 0.0 & 0.0 & 0.0 & 0.0 & \\
\hline 0.0 & 0.0 & 0.0 & 0.0 & 0.0 & 0.0 & 0.0 & 2817.7 & 2876.8 & 2911.2 & \\
\hline 3098.1 & 2855.9 & 2821.7 & 0.0 & 0.0 & 0.0 & 0.0 & 0.0 & 0.0 & 0.0 & \\
\hline 0.0 & 0.0 & 0.0 & 0.0 & 0.0 & 0.0 & 0.0 & 0.0 & 0.0 & 0.0 & \\
\hline 0.0 & 0.0 & 0.0 & 0.0 & 0.0 & 0.0 & 0.0 & 0.0 & 0.0 & 0.0 & \\
\hline LOWER & LAYER ( & AYER 2) & & & ' & & & & & \\
\hline 0.0 & 0.0 & 0.0 & 0.0 & 0.0 & 0.0 & 0.0 & 0.0 & 0.0 & 0.0 & ROW \\
\hline 0.0 & 0.0 & 0.0 & 0.0 & 0.0 & 0.0 & 0.0 & 0.0 & 0.0 & 0.0 & \\
\hline 0.0 & 0.0 & 0.0 & 0.0 & 0.0 & 0.0 & 5388.9 & 5395.8 & 5406.8 & 5452.6 & \\
\hline 5454.0 & 5404.7 & 5274.2 & 5240.7 & 5178.8 & 5042.4 & 4854.8 & 4697.4 & 4547.2 & 4405.3 & \\
\hline 4291.2 & 4211.8 & 4203.6 & 0.0 & 0.0 & 0.0 & 0.0 & 0.0 & 0.0 & 0.0 & \\
\hline 0.0 & 0.0 & 0.0 & 0.0 & 0.0 & 0.0 & 0.0 & 0.0 & 0.0 & 0.0 & \\
\hline 0.0 & 0.0 & 0.0 & 0.0 & 0.0 & 0.0 & 0.0 & 0.0 & 0.0 & 0.0 & ROW \\
\hline 0.0 & 0.0 & 0.0 & 0.0 & 0.0 & 0.0 & 0.0 & 0.0 & 0.0 & 0.0 & \\
\hline 0.0 & 0.0 & 0.0 & 0.0 & 0.0 & 0.0 & 5375.6 & 5382.9 & 5392.9 & 5460.5 & \\
\hline 5435.3 & 5351.1 & 5258.4 & 5261.3 & 5285.7 & 5021.2 & 4793.3 & 4637.3 & 4492.5 & 4363.4 & \\
\hline 4244.4 & 4201.9 & 4200.9 & 0.0 & 0.0 & 0.0 & 0.0 & 0.0 & 0.0 & 0.0 & \\
\hline 0.0 & 0.0 & 0.0 & 0.0 & 0.0 & 0.0 & 0.0 & 0.0 & 0.0 & 0.0 & \\
\hline 0.0 & 0.0 & 0.0 & 0.0 & 0.0 & 0.0 & 0.0 & 0.0 & 0.0 & 0.0 & ROW 3 \\
\hline 0.0 & 0.0 & 0.0 & 0.0 & 0 . & 0.0 & 0.0 & 0.0 & 0.0 & 0.0 & \\
\hline 0.0 & 0.0 & 0.0 & 0.0 & 0.0 & 0.0 & 5353.3 & 5369.0 & 5360.9 & 5329.3 & \\
\hline 5285.8 & 5302.7 & 5001.5 & 4903.2 & 4794.7 & 4521.4 & 4397.7 & 4343.2 & 4310.7 & 4271.4 & \\
\hline 4218.4 & 4199.5 & 4200.0 & 0.0 & 0.0 & 0.0 & 0.0 & 0.0 & 0.0 & 0.0 & \\
\hline 0.0 & 0.0 & 0.0 & 0.0 & 0.0 & 0.0 & 0.0 & 0.0 & 0.0 & 0.0 & \\
\hline 0.0 & 0.0 & 0.0 & 0.0 & 0.0 & 0.0 & 0.0 & 0.0 & 0.0 & 0.0 & ROW \\
\hline 0.0 & 0.0 & 0.0 & 0.0 & 0.0 & 0.0 & 0.0 & 0.0 & 0.0 & 0.0 & \\
\hline 0.0 & 0.0 & 0.0 & 0.0 & 0.0 & 0.0 & 5413.1 & 5398.1 & 5360.7 & 5276.8 & \\
\hline 5080.2 & 4855.1 & 4624.3 & 4597.5 & 4479.2 & 4335.8 & 4261.9 & 4238.9 & 4231.1 & 4230.7 & \\
\hline 1216.7 & 1207.6 & 4203.8 & 4205.0 & 4204.8 & 0.0 & 0.0 & 0.0 & 0.0 & 0.0 & \\
\hline 0.0 & 0.0 & 0.0 & 0.0 & 0.0 & 0.0 & 0.0 & 0.0 & 0.0 & 0.0 & \\
\hline
\end{tabular}




\section{APPENDIX 2. STARTING HEADS USED FOR SIMULATION-Continued}

\begin{tabular}{|c|c|c|c|c|c|c|c|c|c|c|c|}
\hline 0.0 & 0.0 & 0.0 & 0.0 & 0.0 & 0.0 & 0.0 & 0.0 & 0.0 & 0.0 & ROW & 5 \\
\hline 0.0 & 0.0 & 0.0 & 0.0 & 0.0 & 0.0 & 0.0 & 0.0 & 0.0 & 0.0 & & \\
\hline 0.0 & 0.0 & 5863.4 & 5805.6 & 5721.9 & 5614.8 & 5516.2 & 5480.7 & 5450.2 & 5226.7 & & \\
\hline 4856.6 & 4727.0 & 4604.6 & 4576.3 & 4430.5 & 4301.4 & 4248.8 & 4228.1 & 4225.3 & 4237.9 & & \\
\hline 4221.5 & 4215.3 & 4211.7 & 4208.4 & 4206.6 & 4205.3 & 0.0 & 0.0 & 0.0 & 0.0 & & \\
\hline 0.0 & 0.0 & 0.0 & 0.0 & 0.0 & 0.0 & 0.0 & 0.0 & 0.0 & 0.0 & & \\
\hline 0.0 & 0.0 & 0.0 & 0.0 & 0.0 & 0.0 & 0.0 & 0.0 & 0.0 & 0.0 & ROW & 6 \\
\hline 0.0 & 0.0 & 0.0 & 0.0 & 0.0 & 0.0 & 0.0 & 0.0 & 0.0 & 0.0 & & \\
\hline 0.0 & 5752.3 & 5762.5 & 5755.3 & 5734.6 & 5674.2 & 5619.5 & 5606.8 & 5580.2 & 5387.5 & & \\
\hline 4964.3 & 4799.0 & 4710.5 & 4582.9 & 4453.2 & 4362.7 & 4300.7 & 4268.3 & 4261.8 & 4288.6 & & \\
\hline 4248.6 & 4232.2 & 4223.9 & 4214.9 & 4209.9 & 4205.0 & 4202.7 & 4202.6 & 4207.1 & 0.0 & & \\
\hline 0.0 & 0.0 & 0.0 & 0.0 & 0.0 & 0.0 & 0.0 & 0.0 & 0.0 & 0.0 & & \\
\hline 0.0 & 0.0 & 0.0 & 0.0 & 0.0 & 0.0 & 0.0 & 0.0 & 0.0 & 0.0 & ROW & 7 \\
\hline 0.0 & 0.0 & 0.0 & 0.0 & 0.0 & 0.0 & 0.0 & 0.0 & 0.0 & 5472.5 & & \\
\hline 5509.8 & 5568.0 & 5580.3 & 5692.6 & 5716.8 & 5720.4 & 5717.4 & 5725.1 & 5727.6 & 5580.7 & & \\
\hline 5276.4 & 4780.5 & 4828.5 & 4614.9 & 4472.5 & 4386.8 & 4324.5 & 4277.0 & 4251.6 & 4245.5 & & \\
\hline 4240.1 & 4240.2 & 4245.8 & 4242.2 & 4227.7 & 4215.2 & 4210.4 & 4205.6 & 4248.9 & 4305.9 & & \\
\hline 4323.1 & 0.0 & 0.0 & 0.0 & 0.0 & 0.0 & 0.0 & 0.0 & 0.0 & 0.0 & & \\
\hline 0.0 & 0.0 & 0.0 & 0.0 & 0.0 & 0.0 & 0.0 & 0.0 & 0.0 & 0.0 & ROW & 8 \\
\hline 0.0 & 0.0 & 0.0 & 0.0 & 0.0 & 0.0 & 0.0 & 0.0 & 5394.5 & 5428.2 & & \\
\hline 5465.8 & 5515.0 & 5588.1 & 5640.2 & 5779.1 & 5752.8 & 5736.4 & 5971.5 & 5683.6 & 5377.3 & & \\
\hline 4922.8 & 4785.5 & 4723.9 & 4618.9 & 4485.0 & 4402.9 & 4331.8 & 4277.6 & 4247.6 & 4236.9 & & \\
\hline 4235.5 & 4243.3 & 4254.8 & 4255.2 & 4246.2 & 4238.2 & 4241.2 & 4289.6 & 4493.8 & 4611.4 & & \\
\hline 4639.7 & 4674.5 & 4693.0 & 0.0 & 0.0 & 0.0 & 0.0 & 0.0 & 0.0 & 0.0 & & \\
\hline 0.0 & 0.0 & 0.0 & 0.0 & 0.0 & 0.0 & 0.0 & 0.0 & 0.0 & 0.0 & ROW & 9 \\
\hline 0.0 & 0.0 & 0.0 & 0.0 & 0.0 & 0.0 & 0.0 & 5254.2 & 5309.2 & 5377.8 & & \\
\hline 5434.6 & 5826.9 & 6044.6 & 5671.3 & 5755.1 & 5659.4 & 5614.8 & 5771.2 & 5618.7 & 5558.8 & & \\
\hline 5316.9 & 4917.8 & 4743.0 & 4641.4 & 4494.3 & 4384.6 & 4315.7 & 4270.2 & 4245.2 & 4235.2 & & \\
\hline 4236.7 & 4243.8 & 4250.9 & 4263.3 & 4268.2 & 4272.6 & 4280.4 & 4308.6 & 4490.1 & 4671.6 & & \\
\hline 4703.1 & 4733.9 & 4757.3 & 0.0 & 0.0 & 0.0 & 0.0 & 0.0 & 0.0 & 0.0 & & \\
\hline 0.0 & 0.0 & 0.0 & 0.0 & 0.0 & 0.0 & 0.0 & 0.0 & 0.0 & 0.0 & ROW & 10 \\
\hline 0.0 & 0.0 & 0.0 & 0.0 & 0.0 & 0.0 & 5178.6 & 5225.3 & 5290.0 & 5425.0 & & \\
\hline 5674.1 & 6127.5 & 5954.0 & 5689.0 & 5614.6 & 5594.8 & 5600.6 & 5689.7 & 5638.7 & 5591.6 & & \\
\hline 5542.5 & 5436.2 & 4971.7 & 4634.0 & 4455.9 & 4356.4 & 4296.4 & 4260.1 & 4240.5 & 4234.1 & & \\
\hline 4237.1 & 4246.1 & 4253.1 & 4270.4 & 4286.7 & 4299.7 & 4305.5 & 4416.0 & 4590.8 & 4751.6 & & \\
\hline 4792.5 & 4834.9 & 4891.5 & 4942.2 & 4925.1 & 4908.5 & 0.0 & 0.0 & 0.0 & 0.0 & & \\
\hline 0.0 & 0.0 & 0.0 & 0.0 & 0.0 & 0.0 & 0.0 & 0.0 & 0.0 & 0.0 & ROW & 11 \\
\hline 5116.7 & 5103.5 & 5103.7 & 5112.6 & 5136.1 & 5126.9 & 5182.7 & 5330.2 & 5439.7 & 5636.0 & & \\
\hline 5919.3 & 5969.7 & 5842.9 & 5760.7 & 5672.9 & 5651.0 & 5605.3 & 5643.5 & 5642.9 & 5558.1 & & \\
\hline 5505.9 & 5469.6 & 5011.0 & 4458.3 & 4356.4 & 4323.9 & 4293.2 & 4266.1 & 4247.4 & 4238.3 & & \\
\hline 4239.2 & 4245.3 & 4257.1 & 4276.4 & 4304.8 & 4337.5 & 4376.9 & 4458.7 & 4714.3 & 4896.9 & & \\
\hline 4887.4 & 4909.0 & 4956.2 & 4965.4 & 4919.7 & 4867.9 & 4786.9 & 4741.2 & 0.0 & 0.0 & & \\
\hline 0.0 & 0.0 & 0.0 & 0.0 & 0.0 & 0.0 & 0.0 & 0.0 & 4695.3 & 4744.7 & ROW & 12 \\
\hline 4923.5 & 4999.8 & 5002.7 & 5017.5 & 5063.6 & 5138.7 & 5327.0 & 5567.8 & 5888.2 & 6645.2 & & \\
\hline 6869.9 & 6226.8 & 5949.4 & 5912.2 & 5874.8 & 5878.2 & 5830.4 & 5775.9 & 5653.0 & 5451.6 & & \\
\hline 5340.1 & 5151.9 & 4666.6 & 4369.7 & 4262.8 & 4343.1 & 4339.2 & 4306.8 & 4274.2 & 4249.4 & & \\
\hline 4239.1 & 4242.0 & 4249.6 & 4261.5 & 4301.8 & 4378.8 & 4445.0 & 4501.6 & 4764.8 & 5088.0 & & \\
\hline 5009.7 & 4990.1 & 4977.8 & 4951.4 & 4922.6 & 4891.5 & 4800.9 & 4719.8 & 0.0 & 0.0 & & \\
\hline 0.0 & 0.0 & 0.0 & 0.0 & 0.0 & 0.0 & 0.0 & 0.0 & 4702.9 & 4771.1 & ROW & 13 \\
\hline 4850.0 & 4928.3 & 4978.8 & 5027.9 & 5091.5 & 5242.9 & 5413.7 & 5752.8 & 6252.3 & 6944.0 & & \\
\hline 6741.5 & 6230.9 & 6025.8 & 5994.8 & 6034.0 & 5985.0 & 5942.7 & 5817.5 & 5637.5 & 5467.5 & & \\
\hline 5224.2 & 4956.8 & 4673.6 & 4582.5 & 4541.9 & 4589.3 & 4509.9 & 4405.6 & 4328.8 & 4267.5 & & \\
\hline 4240.8 & 4240.6 & 4249.6 & 4262.3 & 4277.2 & 4307.6 & 4402.1 & 4520.2 & 4764.8 & 5128.4 & & \\
\hline 5120.6 & 5069.2 & 5031.8 & 4982.2 & 4946.9 & 4857.1 & 4718.0 & 4591.5 & 0.0 & 0.0 & & \\
\hline 0.0 & 0.0 & 0.0 & 0.0 & 0.0 & 0.0 & 0.0 & 0.0 & 4662.7 & 4741.8 & ROW & \\
\hline 4806.9 & 4904.3 & 5023.9 & 5133.9 & 5218.8 & 5326.0 & 5434.7 & 5654.7 & 6303.3 & 7023.4 & & \\
\hline 6241.4 & 6139.0 & 6091.4 & 6064.6 & 6020.9 & 6031.6 & 5960.7 & 5831.1 & 5686.4 & 5421.7 & & \\
\hline 5029.4 & 4897.2 & 4849.9 & 4833.8 & 4804.9 & 4789.2 & 4714.9 & 4534.2 & 4403.9 & 4299.2 & & \\
\hline 4245.8 & 4232.1 & 4244.8 & 4264.8 & 4298.2 & 4340.9 & 4388.5 & 4435.4 & 4656.0 & 5010.1 & & \\
\hline 5167.2 & 5171.5 & 5150.7 & 5080.7 & 5022.4 & 4948.7 & 4735.5 & 4615.6 & 0.0 & 0.0 & & \\
\hline
\end{tabular}




\section{APPENDIX 2. STARTING HEADS USED FOR SIMULATION-Continued}

\begin{tabular}{|c|c|c|c|c|c|c|c|c|c|c|c|}
\hline 0.0 & 0.0 & 0.0 & 0.0 & 0.0 & 0.0 & 0.0 & 0.0 & 4727.5 & 4755.7 & ROW & 15 \\
\hline 4910.5 & 5056.5 & 5149.8 & 5272.2 & 5659.2 & 5563.4 & 5599.8 & 5708.9 & 6134.4 & 6698.5 & & \\
\hline 168.2 & 6117.1 & 6106.6 & 6109.0 & 6099.9 & 6105.4 & 6034.1 & 5900.3 & 5801.0 & 5602.7 & & \\
\hline 227.2 & 4991.2 & 4984.3 & 5090.4 & 5020.5 & 4975.7 & 4896.3 & 4702.4 & 4512.9 & 4354.7 & & \\
\hline 4276.0 & 4254.9 & 4257.7 & 4275.6 & 4299.0 & 4337.3 & 4388.3 & 4434.6 & 4621.6 & 4967.1 & & \\
\hline 5250.3 & 5302.2 & 5329.1 & 5538.8 & 5364.4 & 5172.6 & 5044.3 & 4904.7 & 0.0 & 0.0 & & \\
\hline 0.0 & 0.0 & 0.0 & 0.0 & 0.0 & 0.0 & 0.0 & 0.0 & 4783.8 & 4854.1 & ROW & 16 \\
\hline 130.5 & 5276.4 & 5206.2 & 5504.1 & 5706.2 & 5673.1 & 5646.8 & 5675.6 & 5944.6 & 6128.9 & & \\
\hline 103.9 & 6097.6 & 6100.3 & 6216.3 & 6196.9 & 6151.4 & 6075.2 & 6019.5 & 5886.1 & 5647.6 & & \\
\hline 05.4 & 5093.0 & 5073.4 & 5100.5 & 5101.6 & 5079.1 & 4985.9 & 4801.3 & 4618.6 & 4444.6 & & \\
\hline 51.7 & 4316.8 & 4295.9 & 4302.8 & 4319.7 & 4347.0 & 4398.3 & 4460.1 & 4538.8 & 4877.5 & & \\
\hline 20.6 & 5289.6 & 5326.3 & 5291.0 & 5261.4 & 5195.9 & 5181.4 & 5070.7 & 5005.8 & 0.0 & & \\
\hline 0.0 & 0.0 & 0.0 & 0.0 & 0.0 & 0.0 & 0.0 & 0.0 & 4856.2 & 5011.6 & ROW & 17 \\
\hline 517.0 & 5426.6 & 5315.1 & 5451.2 & 5808.5 & 5753.3 & 5720.8 & 5724.9 & 5977.8 & 6143.5 & & \\
\hline 15.3 & 6125.1 & 6184.1 & 6357.2 & 6299.4 & 6288.7 & 6324.1 & 6062.4 & 5923.7 & 5850.5 & & \\
\hline 723.9 & 5544.3 & 5324.9 & 5198.4 & 5249.8 & 5278.7 & 4919.5 & 4770.7 & 4674.8 & 4540.2 & & \\
\hline 452.3 & 4360.8 & 4303.5 & 4326.9 & 4339.9 & 4349.4 & 4385.4 & 4433.6 & 4537.8 & 4653.8 & & \\
\hline 746.0 & 4897.1 & 4986.6 & 5045.1 & 5041.9 & 5075.2 & 5122.6 & 5169.4 & 5222.9 & 5316.5 & & \\
\hline 0.0 & 0.0 & 0.0 & 0.0 & 0.0 & 0.0 & 0.0 & 0.0 & 5457.7 & 5585.5 & ROW & \\
\hline 513.7 & 5591.6 & 5554.4 & 5650.5 & 5775.4 & 5768.5 & 5791.6 & 5832.4 & 5939.5 & 6372.1 & & \\
\hline 32.3 & 6308.5 & 6306.4 & 6336.5 & 6320.2 & 6342.1 & 6388.0 & 6067.0 & 6044.3 & 6323.8 & & \\
\hline 25.8 & 5769.2 & 5710.1 & 5604.8 & 5575.1 & 5570.7 & 5483.0 & 5232.1 & 4706.0 & 4576.8 & & \\
\hline 888.7 & 4408.6 & 4369.1 & 4373.9 & 4372.5 & 4383.4 & 4427.4 & 4487.1 & 4553.7 & 4612.3 & & \\
\hline 578.8 & 4726.6 & 4796.4 & 4882.8 & 4946.9 & 5023.3 & 5096.2 & 5159.4 & 5218.5 & 5288.0 & & \\
\hline 0.0 & 0.0 & 0.0 & 0.0 & 0.0 & 0.0 & 0.0 & 0.0 & 5669.6 & 5690.5 & ROW & \\
\hline 596.2 & 5708.8 & 5755.9 & 5807.2 & 5804.9 & 5781.1 & 5834.0 & 5934.0 & 6147.0 & 6340.2 & & \\
\hline 346.6 & 6315.1 & 6291.8 & 6279.8 & 6309.3 & 6449.5 & 6403.4 & 6111.4 & 6103.0 & 6446.0 & & \\
\hline 121.2 & 5883.2 & 5831.1 & 5812.3 & 5838.4 & 5966.3 & 5802.5 & 4906.3 & 4749.2 & 4626.9 & & \\
\hline 532.7 & 4452.2 & 4412.8 & 4411.5 & 4411.5 & 4430.6 & 4454.9 & 4482.9 & 4530.7 & 4578.4 & & \\
\hline 530.2 & 4682.2 & 4741.3 & 4800.0 & 4848.0 & 4974.2 & 5074.3 & 5140.0 & 5198.4 & 5259.0 & & \\
\hline 0.0 & 0.0 & 0.0 & 0.0 & 0.0 & 0.0 & 0.0 & 0.0 & 5698.7 & 5882.8 & ROW & \\
\hline 973.3 & 6027.8 & 6172.7 & 6058.9 & 5800.6 & 5791.9 & 5806.5 & 5871.7 & 5905.6 & 6146.3 & & \\
\hline 263.3 & 6210.4 & 6200.3 & 6195.3 & 6183.5 & 6169.9 & 6154.0 & 6130.4 & 6105.2 & 6118.2 & & \\
\hline 64.4 & 5909.3 & 5882.8 & 5911.4 & 5983.2 & 5851.0 & 5318.0 & 4799.8 & 4721.4 & 4631.5 & & \\
\hline 546.4 & 4479.8 & 4448.2 & 4446.4 & 4443.1 & 4449.9 & 4458.5 & 4499.8 & 4536.7 & 4571.9 & & \\
\hline 509.6 & 4656.4 & 4712.4 & 4779.7 & 4873.6 & 5015.7 & 5106.2 & 5137.0 & 5166.0 & 5183.8 & & \\
\hline 0.0 & 0.0 & 0.0 & 0.0 & 0.0 & 0.0 & 0.0 & 0.0 & 5729.1 & 5991.2 & ROW & \\
\hline 029.8 & 6012.2 & 5968.5 & 5934.6 & 5880.8 & 5855.5 & 5857.6 & 5892.5 & 5893.7 & 6116.6 & & \\
\hline 153.5 & 6159.6 & 6167.5 & 6172.5 & 6166.3 & 6149.4 & 6140.5 & 6127.9 & 6116.5 & 6129.7 & & \\
\hline 203.1 & 5879.1 & 5806.6 & 5841.0 & 5834.6 & 5601.6 & 5160.2 & 4905.6 & 4755.4 & 4626.5 & & \\
\hline 4521.6 & 4492.1 & 4479.3 & 4478.5 & 4471.2 & 4474.2 & 4489.3 & 4517.2 & 4544.4 & 4570.0 & & \\
\hline 594.0 & 4644.2 & 4702.0 & 4779.0 & 4885.9 & 5030.0 & 5131.8 & 5209.9 & 5197.0 & 5191.7 & & \\
\hline 0.0 & 0.0 & 0.0 & 0.0 & 0.0 & 0.0 & 0.0 & 0.0 & 5853.3 & 6062.1 & ROW & 22 \\
\hline 56.1 & 6050.7 & 6024.0 & 5995.4 & 5977.2 & 5944.1 & 5935.0 & 5942.0 & 5884.9 & 6068.7 & & \\
\hline 132.5 & 6139.4 & 6147.8 & 6160.2 & 6164.6 & 6143.7 & 6129.3 & 6101.0 & 6110.5 & 6131.7 & & \\
\hline 6175.6 & 5761.7 & 5670.6 & 5827.6 & 5978.0 & 5933.3 & 5188.1 & 4888.4 & 4810.6 & 4723.9 & & \\
\hline 4582.8 & 4518.8 & 4511.8 & 4510.8 & 4496.1 & 4501.9 & 4517.9 & 4535.4 & 4555.1 & 4578.0 & & \\
\hline 505.6 & 4643.2 & 4697.8 & 4773.3 & 4882.8 & 5021.6 & 5149.1 & 5234.1 & 5244.1 & 5222.6 & & \\
\hline 0.0 & 0.0 & 0.0 & 0.0 & 0.0 & 6150.6 & 6079.0 & 6017.6 & 6045.1 & 6089.3 & ROW & 23 \\
\hline 070.3 & 6043.1 & 6023.1 & 6004.8 & 6002.6 & 6028.5 & 6023.5 & 6025.0 & 5901.8 & 5979.1 & & \\
\hline 6101.7 & 6113.4 & 6131.2 & 6163.3 & 6202.2 & 6210.2 & 6173.6 & 6160.3 & 6158.8 & 6178.1 & & \\
\hline 6215.3 & 6035.4 & 5798.7 & 5777.9 & 6043.2 & 6153.5 & 5369.3 & 4993.3 & 4934.9 & 4804.9 & & \\
\hline 4643.7 & 4553.0 & 4544.8 & 4544.8 & 4543.7 & 4542.3 & 4545.9 & 4552.1 & 4563.9 & 4585.3 & & \\
\hline 616.4 & 4652.7 & 4710.5 & 4786.4 & 4886.5 & 5030.9 & 5173.0 & 5275.0 & 5313.1 & 0.0 & & \\
\hline 0.0 & 0.0 & 0.0 & 0.0 & 0.0 & 6030.9 & 5969.5 & 6024.4 & 6178.1 & 6165.4 & ROW & \\
\hline 113.2 & 6079.3 & 6050.0 & 6049.4 & 6083.9 & 6194.5 & 6107.3 & 6066.8 & 6010.3 & 6019.7 & & \\
\hline 060.6 & 6070.2 & 6115.0 & 6154.3 & 6180.6 & 6257.5 & 6215.0 & 6182.2 & 6196.2 & 6226.1 & & \\
\hline 281.7 & 6116.7 & 6074.4 & 6051.8 & 6105.7 & 6128.7 & 5311.3 & 5137.5 & 5043.2 & 4886.2 & & \\
\hline 704.9 & 4584.7 & 4575.9 & 4580.6 & 4591.0 & 4584.8 & 4574.2 & 4567.0 & 4561.4 & 4584.9 & & \\
\hline 636.3 & 4651.9 & 4747.5 & 4834.0 & 4938.6 & 5096.5 & 5249.1 & 5343.6 & 5375.4 & 0.0 & & \\
\hline
\end{tabular}


APPENDIX 2. STARTING HEADS USED FOR SIMULATION-Continued

\begin{tabular}{|c|c|c|c|c|c|c|c|c|c|c|c|}
\hline 0.0 & 0.0 & 0.0 & 0.0 & 0.0 & 5733.5 & 5728.6 & 5774.4 & 6063.7 & 6311.3 & ROW & N 25 \\
\hline 6337.0 & 6230.8 & 6125.2 & 6077.2 & 6082.9 & 6101.3 & 6052.5 & 6013.7 & 6006.6 & 5994.4 & & \\
\hline 002.2 & 6011.2 & 6048.4 & 6102.2 & 6114.1 & 6098.2 & 6094.2 & 6100.9 & 6242.2 & 6277.5 & & \\
\hline 425.0 & 6167.9 & 6106.6 & 6036.2 & 5983.9 & 5814.9 & 5463.8 & 5157.7 & 5101.9 & 4969.2 & & \\
\hline 832.8 & 4680.0 & 4611.9 & 4621.3 & 4629.9 & 4621.9 & 4613.6 & 4622.0 & 4654.0 & 4698.2 & & \\
\hline 746.7 & 4794.5 & 4857.0 & 4927.4 & 5022.8 & 5205.8 & 5390.4 & 5644.9 & 0.0 & 0.0 & & \\
\hline 0.0 & 0.0 & 0.0 & 0.0 & 0.0 & 5660.0 & 5660.7 & 5663.3 & 6090.0 & 6457.1 & ROW & \\
\hline 496.4 & 6455.4 & 6281.4 & 6093.0 & 6062.4 & 6049.5 & 6040.4 & 6055.5 & 6092.8 & 5945.2 & & \\
\hline 5921.3 & 5933.7 & 5976.7 & 6051.7 & 6041.4 & 5967.7 & 5929.1 & 5948.6 & 6146.1 & 6341.2 & & \\
\hline 5403.3 & 6276.4 & 6071.3 & 6019.5 & 5935.3 & 5870.5 & 5373.7 & 5204.1 & 5165.6 & 5034.0 & & \\
\hline 918.2 & 4760.1 & 4651.7 & 4645.0 & 4649.4 & 4661.3 & 4657.3 & 4671.5 & 4734.5 & 4802.5 & & \\
\hline 869.4 & 4933.8 & 4996.2 & 5036.9 & 5309.3 & 5653.5 & 5695.1 & 5768.4 & 0.0 & 0.0 & & \\
\hline 0.0 & 0.0 & 0.0 & 0.0 & 5621.5 & 5634.5 & 5636.2 & 5791.6 & 6439.9 & 6538.9 & ROW & \\
\hline 6571.4 & 6596.9 & 6648.1 & 6163.8 & 6075.6 & 6057.5 & 6054.2 & 6084.8 & 6104.8 & 5827.6 & & \\
\hline 5810.6 & 5851.5 & 5876.8 & 5954.9 & 6004.9 & 5827.4 & 5820.8 & 5828.5 & 5830.8 & 6384.9 & & \\
\hline 5431.0 & 6420.6 & 6044.6 & 5918.2 & 5859.4 & 5795.4 & 5539.4 & 5314.1 & 5287.3 & 5203.5 & & \\
\hline 044.0 & 4855.5 & 4695.6 & 4672.9 & 4678.3 & 4684.7 & 4685.2 & 4706.4 & 4864.7 & 4923.5 & & \\
\hline 4999.3 & 5095.8 & 5208.7 & 5513.5 & 5865.0 & 6085.2 & 0.0 & 0.0 & 0.0 & 0.0 & & \\
\hline 0.0 & 0.0 & 0.0 & 0.0 & 5593.9 & 5596.0 & 5602.4 & 6288.2 & 6540.0 & 6570.3 & ROW & 28 \\
\hline 6596.8 & 6626.1 & 6614.8 & 6393.2 & 6298.2 & 6290.2 & 6069.9 & 6011.0 & 5882.5 & 5695.7 & & \\
\hline 5606.8 & 5634.2 & 5692.2 & 5788.6 & 5837.1 & 5759.5 & 5734.6 & 5651.4 & 5712.2 & 6658.9 & & \\
\hline 311.3 & 6224.8 & 6053.1 & 5958.9 & 5863.1 & 5905.5 & 5815.8 & 5581.4 & 5387.7 & 5388.7 & & \\
\hline 5262.4 & 5128.6 & 4890.1 & 4739.1 & 4697.1 & 4698.0 & 4702.4 & 4930.4 & 4990.7 & 5027.2 & & \\
\hline 107.3 & 5258.9 & 5497.9 & 5804.1 & 6048.1 & 6221.9 & 0.0 & 0.0 & 0.0 & 0.0 & & \\
\hline 0.0 & 0.0 & 0.0 & 0.0 & 5592.6 & 5586.1 & 5598.1 & 6120.1 & 6547.9 & 6590.5 & ROW & N 29 \\
\hline 6620.6 & 6653.8 & 6570.1 & 6275.0 & 6113.2 & 6102.2 & 6091.6 & 5981.5 & 5769.4 & 5566.5 & & \\
\hline 5465.2 & 5240.3 & 5309.7 & 5480.9 & 5785.4 & 5689.2 & 5644.7 & 5646.1 & 5687.1 & 5698.7 & & \\
\hline 5753.0 & 6096.9 & 6011.2 & 5911.1 & 5889.3 & 5885.5 & 5865.0 & 5750.9 & 5576.3 & 5661.9 & & \\
\hline 5507.7 & 5314.3 & 5103.0 & 4866.3 & 4711.4 & 4710.9 & 4717.1 & 5108.4 & 5073.7 & 5092.4 & & \\
\hline 153.2 & 5273.2 & 5967.5 & 6326.5 & 6492.9 & 6596.5 & 6709.9 & 0.0 & 0.0 & 0.0 & & \\
\hline 0.0 & 0.0 & 0.0 & 0.0 & 5610.8 & 5607.5 & 5612.7 & 6290.5 & 6580.3 & 6611.4 & ROW & \\
\hline 6628.1 & 6638.8 & 6413.3 & 6174.4 & 6110.7 & 6089.2 & 6066.6 & 5878.4 & 5614.6 & 5423.1 & & \\
\hline 5233.1 & 5022.6 & 4991.7 & 5219.6 & 5457.3 & 5678.8 & 5537.2 & 5567.7 & 5616.7 & 5620.6 & & \\
\hline 5858.6 & 5995.7 & 5960.3 & 5932.4 & 5921.5 & 5912.5 & 5870.8 & 5802.4 & 5839.7 & 5915.5 & & \\
\hline 5872.4 & 5664.0 & 5447.8 & 5021.7 & 4724.0 & 4721.1 & 4729.3 & 5368.0 & 5101.2 & 5090.6 & & \\
\hline 5117.3 & 5351.8 & 6101.1 & 6238.5 & 6366.3 & 6573.8 & 6724.5 & 6810.5 & 0.0 & 0.0 & & \\
\hline 0.0 & 0.0 & 0.0 & 0.0 & 5636.8 & 5623.2 & 5625.7 & 6331.6 & 6601.1 & 6626.1 & ROW & 31 \\
\hline 633.0 & 6620.6 & 6424.6 & 6097.2 & 6025.6 & 5953.8 & 5858.2 & 5619.8 & 5383.1 & 5147.7 & & \\
\hline 4983.4 & 4882.4 & 4813.3 & 4915.8 & 5415.5 & 5430.0 & 5418.3 & 5290.3 & 5442.4 & 5490.3 & & \\
\hline 5598.6 & 5871.4 & 5915.3 & 5929.3 & 5982.7 & 6040.4 & 6062.0 & 5989.2 & 6020.6 & 6112.7 & & \\
\hline 6133.3 & 6005.9 & 5761.9 & 5450.1 & 4887.8 & 4882.9 & 4994.3 & 5060.3 & 5043.5 & 5022.9 & & \\
\hline 5077.9 & 5281.2 & 5747.9 & 6104.4 & 6238.3 & 6450.8 & 6629.5 & 6728.9 & 0.0 & 0.0 & & \\
\hline 0.0 & 0.0 & 0.0 & 0.0 & 5688.5 & 5648.9 & 5650.7 & 6340.4 & 6610.3 & 6633.8 & ROW & \\
\hline 6634.0 & 6606.7 & 6276.0 & 5738.2 & 5750.0 & 5714.7 & 5620.9 & 5419.6 & 5147.3 & 4893.7 & & \\
\hline 4810.4 & 4744.9 & 4762.1 & 4765.4 & 4929.9 & 5178.2 & 5307.6 & 5284.7 & 5291.9 & 5327.0 & & \\
\hline 5324.9 & 5638.7 & 5920.6 & 5951.5 & 6100.4 & 6293.2 & 6474.0 & 6342.3 & 6290.4 & 6318.0 & & \\
\hline 6386.2 & 6532.0 & 6335.9 & 6273.7 & 6163.9 & 5646.6 & 5236.9 & 5047.8 & 5033.0 & 5047.2 & & \\
\hline 5132.5 & 5373.6 & 5679.9 & 5965.6 & 6164.8 & 6368.7 & 6533.1 & 6644.2 & 0.0 & 0.0 & & \\
\hline 0.0 & 0.0 & 0.0 & 0.0 & 5640.5 & 5623.9 & 5669.0 & 6273.0 & 6595.8 & 6682.3 & ROW & v 33 \\
\hline 6692.5 & 6538.8 & 6113.4 & 5688.4 & 5620.3 & 5546.4 & 5466.3 & 5361.9 & 5233.4 & 4963.7 & & \\
\hline 4799.0 & 4774.8 & 4777.7 & 4783.5 & 4914.4 & 5124.3 & 5238.9 & 5221.8 & 5224.4 & 5226.7 & & \\
\hline 5262.7 & 5481.1 & 5663.4 & 5895.5 & 6142.0 & 6564.9 & 6728.8 & 6390.2 & 6392.4 & 6481.3 & & \\
\hline 6504.2 & 6649.1 & 6672.5 & 6438.7 & 6243.0 & 5722.0 & 5235.3 & 5100.2 & 5099.1 & 5181.5 & & \\
\hline 5312.4 & 5486.4 & 5685.5 & 5878.3 & 6050.1 & 6241.0 & 6378.7 & 0.0 & 0.0 & 0.0 & & \\
\hline 0.0 & 0.0 & 0.0 & 5403.2 & 5436.0 & 5493.3 & 5576.6 & 5903.8 & 6204.0 & 6511.1 & ROW & v 34 \\
\hline 6657.8 & 6159.4 & 5951.4 & 5730.6 & 5570.7 & 5438.7 & 5364.7 & 5311.0 & 5154.0 & 4918.8 & & \\
\hline 4765.4 & 4758.2 & 4823.8 & 4803.0 & 5047.3 & 5088.4 & 5116.6 & 5052.8 & 5045.1 & 5053.0 & & \\
\hline 5035.0 & 5138.6 & 5264.7 & 5568.7 & 5883.3 & 5982.8 & 6076.2 & 6079.3 & 6154.5 & 6294.1 & & \\
\hline 6376.8 & 6358.0 & 6295.2 & 6191.5 & 5733.1 & 5466.4 & 5283.7 & 5173.9 & 5199.0 & 5311.9 & & \\
\hline 5413.7 & 5555.0 & 5720.0 & 5883.6 & 6044.7 & 6158.6 & 0.0 & 0.0 & 0.0 & 0.0 & & \\
\hline
\end{tabular}




\section{APPENDIX 2. STARTING HEADS USED FOR SIMULATION-Continued}

\begin{tabular}{|c|c|c|c|c|c|c|c|c|c|c|c|}
\hline 0.0 & 0.0 & 5199.1 & 5096.4 & 5167.3 & 5262.0 & 5327.4 & 5462.4 & 5598.7 & 5769.7 & ROW & 35 \\
\hline 5782.3 & 5701.9 & 5662.7 & 5613.3 & 5471.6 & 5341.8 & 5237.4 & 5222.6 & 5067.8 & 4881.2 & & \\
\hline 4850.4 & 4975.3 & 5080.6 & 5134.1 & 5037.9 & 4976.1 & 4964.7 & 4907.4 & 4872.7 & 4886.6 & & \\
\hline 4855.4 & 4871.4 & 5015.9 & 5395.2 & 5794.9 & 5585.1 & 5518.9 & 5638.8 & 5746.7 & 5950.8 & & \\
\hline 6122.2 & 5961.9 & 5766.9 & 5472.5 & 5395.8 & 5330.2 & 5280.7 & 5266.0 & 5280.0 & 5327.1 & & \\
\hline 5426.2 & 5589.4 & 5778.7 & 5951.8 & 6078.2 & 6337.3 & 0.0 & 0.0 & 0.0 & 0.0 & & \\
\hline 4630.8 & 4661.8 & 4804.1 & 4842.4 & 4894.5 & 4991.7 & 5509.4 & 5474.7 & 5508.7 & 5574.3 & ROW & 36 \\
\hline 5607.8 & 5591.7 & 5554.9 & 5481.8 & 5456.9 & 5438.4 & 5331.0 & 5243.2 & 5092.5 & 5095.5 & & \\
\hline 5304.0 & 5616.1 & 5514.6 & 5149.3 & 4922.0 & 4870.6 & 4824.8 & 4776.8 & 4760.5 & 4761.6 & & \\
\hline 4757.6 & 4780.4 & 4780.7 & 5007.6 & 5650.2 & 5220.1 & 5097.8 & 5005.3 & 5144.0 & 5447.7 & & \\
\hline 5592.7 & 5549.8 & 5414.4 & 5382.0 & 5360.5 & 5332.4 & 5304.2 & 5304.1 & 5331.0 & 5365.9 & & \\
\hline 5469.4 & 5657.1 & 5846.9 & 5999.3 & 6095.9 & 0.0 & 0.0 & 0.0 & 0.0 & 0.0 & & \\
\hline 4596.6 & 4632.9 & 4694.6 & 4747.3 & 4761.8 & 4849.6 & 5142.6 & 5243.6 & 5317.6 & 5455.1 & ROW & \\
\hline 5480.7 & 5500.7 & 5495.3 & 5464.1 & 5443.5 & 5425.0 & 5375.1 & 5267.4 & 5096.3 & 5058.3 & & \\
\hline 5307.9 & 5411.6 & 5212.4 & 5032.4 & 4870.7 & 4759.6 & 4672.1 & 4627.5 & 4644.3 & 4649.0 & & \\
\hline 4672.3 & 4710.1 & 4727.0 & 4713.0 & 4758.0 & 4823.2 & 4830.3 & 4771.4 & 4845.4 & 5079.7 & & \\
\hline 5273.9 & 5381.8 & 5369.2 & 5359.8 & 5351.3 & 5344.3 & 5345.7 & 5356.4 & 5376.3 & 5398.1 & & \\
\hline 5498.6 & 5687.2 & 5862.4 & 5970.8 & 0.0 & 0.0 & 0.0 & 0.0 & 0.0 & 0.0 & & \\
\hline 1575.6 & 4592.8 & 4621.4 & 4648.6 & 4665.4 & 4717.5 & 4863.4 & 4998.5 & 5072.0 & 5241.8 & ROW & \\
\hline 5404.9 & 5439.2 & 5443.4 & 5443.1 & 5445.9 & 5358.9 & 5268.3 & 5140.5 & 5053.8 & 4989.0 & & \\
\hline 4960.6 & 4919.3 & 4879.3 & 4823.9 & 4722.9 & 4589.2 & 4482.7 & 4496.2 & 4532.0 & 4537.9 & & \\
\hline 4479.5 & 4471.0 & 4530.7 & 4526.8 & 4544.6 & 4588.3 & 4618.1 & 4632.2 & 4688.8 & 4877.9 & & \\
\hline 5039.3 & 5186.3 & 5222.9 & 5247.6 & 5309.5 & 5360.4 & 5407.1 & 5450.2 & 5467.0 & 0.0 & & \\
\hline 0.0 & 0.0 & 0.0 & 0.0 & 0.0 & 0.0 & 0.0 & 0.0 & 0.0 & 0.0 & & \\
\hline 4540.9 & 4548.2 & 4563.8 & 4579.1 & 4591.1 & 4636.9 & 4755.9 & 5092.2 & 5122.5 & 5198.3 & ROW & \\
\hline 5296.4 & 5359.5 & 5390.1 & 5407.3 & 5467.9 & 5545.7 & 5246.8 & 5095.0 & 5032.2 & 4957.8 & & \\
\hline 4884.7 & 4817.6 & 4793.4 & 4785.7 & 4605.0 & 4278.7 & 4182.3 & 4219.0 & 4251.3 & 4269.0 & & \\
\hline 4225.4 & 4184.3 & 4247.2 & 4314.2 & 4301.8 & 4417.4 & 4436.4 & 4489.3 & 4506.5 & 4679.7 & & \\
\hline 902.8 & 4994.7 & 5027.0 & 5055.3 & 5200.8 & 5350.4 & 5446.5 & 5505.2 & 0.0 & 0.0 & & \\
\hline 0.0 & 0.0 & 0.0 & 0.0 & 0.0 & 0.0 & 0.0 & 0.0 & 0.0 & 0.0 & & \\
\hline 4505.8 & 4511.4 & 4510.5 & 4522.5 & 4531.3 & 4549.8 & 4667.6 & 4911.7 & 5040.6 & 5142.2 & ROW & 40 \\
\hline 5253.1 & 5291.4 & 5321.8 & 5354.5 & 5377.8 & 5404.4 & 5416.2 & 5059.8 & 5000.6 & 4955.7 & & \\
\hline 4899.3 & 4837.2 & 4773.4 & 4745.8 & 4642.3 & 4065.1 & 3990.3 & 3945.2 & 3811.7 & 3874.1 & & \\
\hline 4020.1 & 3976.1 & 3968.0 & 3974.1 & 3993.9 & 4071.5 & 4134.3 & 4180.4 & 4239.9 & 4346.2 & & \\
\hline 4596.2 & 4749.0 & 4752.2 & 4790.7 & 0.0 & 0.0 & 0.0 & 0.0 & 0.0 & 0.0 & & \\
\hline 0.0 & 0.0 & 0.0 & 0.0 & 0.0 & 0.0 & 0.0 & 0.0 & 0.0 & 0.0 & & \\
\hline 4480.9 & 4483.2 & 4476.4 & 4479.5 & 4490.5 & 4536.7 & 4667.0 & 4888.9 & 4843.5 & 4852.9 & ROW & 41 \\
\hline 4937.7 & 5076.9 & 5182.0 & 5215.1 & 5256.7 & 5330.3 & 5441.4 & 5145.4 & 5049.5 & 5002.9 & & \\
\hline 4929.0 & 4866.2 & 4817.3 & 4599.5 & 4213.0 & 3879.0 & 3856.8 & 3800.4 & 3695.4 & 3611.6 & & \\
\hline 3687.5 & 3776.1 & 3831.7 & 3872.1 & 3854.9 & 3837.1 & 3811.4 & 3794.6 & 3827.4 & 3920.7 & & \\
\hline 014.6 & 4131.0 & 4063.0 & 4206.0 & 0.0 & 0.0 & 0.0 & 0.0 & 0.0 & 0.0 & & \\
\hline 0.0 & 0.0 & 0.0 & 0.0 & 0.0 & 0.0 & 0.0 & 0.0 & 0.0 & 0.0 & & \\
\hline 4481.9 & 4459.2 & 4429.3 & 4428.1 & 4439.5 & 4439.8 & 4453.6 & 4480.5 & 4506.5 & 4543.9 & ROW & 42 \\
\hline 4567.8 & 4703.8 & 4858.3 & 4940.2 & 5009.1 & 5041.4 & 5045.4 & 5033.8 & 5058.0 & 5113.4 & & \\
\hline 4903.9 & 4739.0 & 4551.0 & 4211.7 & 3979.9 & 3838.1 & 3798.4 & 3735.3 & 3652.5 & 3566.2 & & \\
\hline 3503.7 & 3480.7 & 3505.2 & 3472.2 & 3546.2 & 3604.9 & 3455.2 & 3336.6 & 3380.6 & 3475.7 & & \\
\hline 3494.2 & 3505.5 & 3478.9 & 3592.9 & 0.0 & 0.0 & 0.0 & 0.0 & 0.0 & 0.0 & & \\
\hline 0.0 & 0.0 & 0.0 & 0.0 & 0.0 & 0.0 & 0.0 & 0.0 & 0.0 & 0.0 & & \\
\hline 4605.9 & 4561.7 & 4511.7 & 4481.1 & 4460.4 & 4426.6 & 4391.0 & 4399.7 & 4413.8 & 4450.3 & ROW & 43 \\
\hline 4467.4 & 4528.0 & 4625.1 & 4709.2 & 4784.6 & 4856.8 & 4865.9 & 4913.5 & 4933.6 & 4980.7 & & \\
\hline 4813.9 & 4600.9 & 4271.6 & 3893.1 & 3775.0 & 3648.9 & 3600.3 & 3509.9 & 3473.2 & 3426.0 & & \\
\hline 3376.6 & 3302.3 & 3242.1 & 3271.9 & 3217.3 & 3232.1 & 2956.8 & 2911.7 & 2921.2 & 2907.4 & & \\
\hline 2904.7 & 2876.2 & 2806.7 & 2869.6 & 2773.4 & 0.0 & 0.0 & 0.0 & 0.0 & 0.0 & & \\
\hline 0.0 & 0.0 & 0.0 & 0.0 & 0.0 & 0.0 & 0.0 & 0.0 & 0.0 & 0.0 & & \\
\hline 0.0 & 0.0 & 0.0 & 4558.6 & 4485.7 & 4438.0 & 4407.1 & 4365.1 & 4344.5 & 4350.3 & ROW & 44 \\
\hline 4369.3 & 4406.2 & 4439.7 & 4497.2 & 4559.4 & 4625.0 & 4706.1 & 4788.5 & 4810.0 & 4615.8 & & \\
\hline 4356.4 & 4200.7 & 3804.7 & 3575.2 & 3515.6 & 3470.5 & 3454.5 & 3389.4 & 3275.3 & 3099.3 & & \\
\hline 2958.7 & 2819.4 & 2772.6 & 2717.1 & 2571.1 & 2422.3 & 2381.5 & 2477.6 & 2485.0 & 2301.2 & & \\
\hline 2237.0 & 2275.4 & 2317.3 & 2398.3 & 2444.2 & 0.0 & 0.0 & 0.0 & 0.0 & 0.0 & & \\
\hline 0.0 & 0.0 & 0.0 & 0.0 & 0.0 & 0.0 & 0.0 & 0.0 & 0.0 & 0.0 & & \\
\hline
\end{tabular}




\section{APPENDIX 2. STARTING HEADS USED FOR SIMULATION-Continued}

\begin{tabular}{|c|c|c|c|c|c|c|c|c|c|c|c|}
\hline 0.0 & 0.0 & 0.0 & 4295.1 & 4279.4 & 4403.5 & 4868.4 & 4203.3 & 4042.8 & 4026.2 & ROW & 45 \\
\hline 4106.2 & 4219.6 & 4291.2 & 4331.5 & 4391.2 & 4438.0 & 4469.6 & 4489.1 & 4481.4 & 4106.4 & & \\
\hline 3089.4 & 3016.2 & 2983.6 & 3170.3 & 3305.7 & 3446.4 & 3573.2 & 3385.9 & 2932.3 & 2610.6 & & \\
\hline 2550.5 & 2400.9 & 2307.8 & 2253.5 & 2192.9 & 2126.0 & 2092.6 & 2110.4 & 2065.5 & 2070.2 & & \\
\hline 2101.3 & 2134.7 & 2152.4 & 2154.9 & 2180.5 & 0.0 & 0.0 & 0.0 & 0.0 & 0.0 & & \\
\hline 0.0 & 0.0 & 0.0 & 0.0 & 0.0 & 0.0 & 0.0 & 0.0 & 0.0 & 0.0 & & \\
\hline 0.0 & 0.0 & 0.0 & 3829.7 & 3633.0 & 3563.2 & 3533.9 & 3544.0 & 3672.0 & 3781.4 & ROW & 46 \\
\hline 3874.0 & 3969.7 & 4067.6 & 4080.7 & 4169.9 & 4222.8 & 4236.8 & 4226.9 & 4010.5 & 3650.4 & & \\
\hline 2848.4 & 2839.1 & 2842.0 & 2862.2 & 2982.8 & 2985.6 & 2833.3 & 2868.7 & 2657.4 & 2626.2 & & \\
\hline 2485.8 & 2274.7 & 2206.2 & 2161.9 & 2099.7 & 2046.1 & 2008.8 & 1993.9 & 1995.8 & 2005.7 & & \\
\hline 2021.1 & 2009.9 & 2005.3 & 2002.5 & 0.0 & 0.0 & 0.0 & 0.0 & 0.0 & 0.0 & & \\
\hline 0.0 & 0.0 & 0.0 & 0.0 & 0.0 & 0.0 & 0.0 & 0.0 & 0.0 & 0.0 & & \\
\hline 0.0 & 0.0 & 0.0 & 0.0 & 3096.5 & 3050.8 & 3080.1 & 3147.2 & 3488.2 & 3657.2 & ROW & 47 \\
\hline 3598.5 & 3691.6 & 3876.4 & 3691.1 & 3632.2 & 3619.7 & 3599.7 & 3528.3 & 3559.5 & 3037.2 & & \\
\hline 2767.8 & 2767.4 & 2770.8 & 2840.2 & 2976.1 & 2875.2 & 2800.0 & 2779.7 & 2742.0 & 2694.4 & & \\
\hline 2507.6 & 2206.6 & 2152.9 & 2110.6 & 2048.8 & 1975.8 & 1932.4 & 1940.1 & 1950.5 & 1943.8 & & \\
\hline 1926.4 & 1911.7 & 0.0 & 0.0 & 0.0 & 0.0 & 0.0 & 0.0 & 0.0 & 0.0 & & \\
\hline 0.0 & 0.0 & 0.0 & 0.0 & 0.0 & 0.0 & 0.0 & 0.0 & 0.0 & 0.0 & & \\
\hline 0.0 & 0.0 & 0.0 & 0.0 & 0.0 & 2828.5 & 2780.1 & 2761.9 & 2751.1 & 2779.7 & ROW & 48 \\
\hline 2782.1 & 2934.3 & 3064.3 & 3335.8 & 3126.0 & 2934.3 & 2816.9 & 2709.9 & 2635.6 & 2642.3 & & \\
\hline 2671.5 & 2686.7 & 2703.1 & 2715.1 & 2738.4 & 2761.7 & 2777.4 & 2772.6 & 2727.3 & 2609.9 & & \\
\hline 2388.4 & 2206.8 & 2148.2 & 2072.9 & 1971.4 & 1871.2 & 1805.2 & 1842.7 & 1847.6 & 1825.7 & & \\
\hline 1804.5 & 0.0 & 0.0 & 0.0 & 0.0 & 0.0 & 0.0 & 0.0 & 0.0 & 0.0 & & \\
\hline 0.0 & 0.0 & 0.0 & 0.0 & 0.0 & 0.0 & 0.0 & 0.0 & 0.0 & 0.0 & & \\
\hline 0.0 & 0.0 & 0.0 & 0.0 & 0.0 & 0.0 & 0.0 & 2528.8 & 2053.3 & 1723.5 & ROW & 49 \\
\hline 1565.8 & 1607.5 & 1998.2 & 2552.0 & 2514.5 & 2503.6 & 2557.1 & 2568.3 & 2572.8 & 2586.4 & & \\
\hline 2610.3 & 2636.3 & 2664.4 & 2689.0 & 2729.3 & 2772.2 & 2788.6 & 2797.7 & 2790.5 & 2645.6 & & \\
\hline 2435.9 & 2216.7 & 2150.6 & 2070.5 & 1991.4 & 1927.9 & 1877.3 & 1772.8 & 1740.9 & 1699.3 & & \\
\hline 1521.0 & 0.0 & 0.0 & 0.0 & 0.0 & 0.0 & 0.0 & 0.0 & 0.0 & 0.0 & & \\
\hline 0.0 & 0.0 & 0.0 & 0.0 & 0.0 & 0.0 & 0.0 & 0.0 & 0.0 & 0.0 & & \\
\hline 0.0 & 0.0 & 0.0 & 0.0 & 0.0 & 0.0 & 0.0 & 0.0 & 0.0 & 337.8 & ROW & \\
\hline 384.5 & 439.3 & 852.6 & 1523.6 & 2092.6 & 2296.0 & 2381.0 & 2461.6 & 2496.4 & 2512.6 & & \\
\hline 2542.7 & 2572.1 & 2630.8 & 2707.0 & 2769.8 & 2809.7 & 2830.2 & 2848.2 & 2790.2 & 2697.7 & & \\
\hline 2605.8 & 2387.7 & 2256.3 & 2114.7 & 2000.1 & 1946.2 & 1922.7 & 1910.7 & 1684.4 & 1580.2 & & \\
\hline 1402.3 & 0.0 & 0.0 & 0.0 & 0.0 & 0.0 & 0.0 & 0.0 & 0.0 & 0.0 & & \\
\hline 0.0 & 0.0 & 0.0 & 0.0 & 0.0 & 0.0 & 0.0 & 0.0 & 0.0 & 0.0 & & \\
\hline 0.0 & 0.0 & 0.0 & 0.0 & 0.0 & 0.0 & 0.0 & 0.0 & 0.0 & 0.0 & ROW & 51 \\
\hline-69.7 & -116.1 & 120.4 & 829.5 & 1627.4 & 2013.0 & 2200.4 & 2336.8 & 2408.4 & 2422.4 & & \\
\hline 2476.4 & 2527.0 & 2617.8 & 2757.8 & 2852.7 & 2881.8 & 2903.2 & 2949.0 & 2857.1 & 2723.8 & & \\
\hline 2577.3 & 2420.0 & 2289.4 & 2162.7 & 2053.2 & 1978.6 & 1935.3 & 1851.6 & 1688.6 & 1491.2 & & \\
\hline 1310.7 & 0.0 & 0.0 & 0.0 & 0.0 & 0.0 & 0.0 & 0.0 & 0.0 & 0.0 & & \\
\hline 0.0 & 0.0 & 0.0 & 0.0 & 0.0 & 0.0 & 0.0 & 0.0 & 0.0 & 0.0 & & \\
\hline 0.0 & 0.0 & 0.0 & 0.0 & 0.0 & 0.0 & 0.0 & 0.0 & 0.0 & 0.0 & ROW & 52 \\
\hline 0.0 & 0.0 & -64.9 & 202.1 & 867.5 & 1497.7 & 1957.2 & 2255.8 & 2301.7 & 2281.9 & & \\
\hline 2300.5 & 2459.0 & 2733.3 & 2992.4 & 3095.5 & 32.63 .1 & 3357.2 & 3385.9 & 3065.9 & 2814.4 & & \\
\hline 2598.0 & 2403.4 & 2235.4 & 2110.2 & 1957.1 & 1813.8 & 1696.3 & 1549.7 & 1357.8 & 1276.8 & & \\
\hline 1238.4 & 0.0 & 0.0 & 0.0 & 0.0 & 0.0 & 0.0 & 0.0 & 0.0 & 0.0 & & \\
\hline 0.0 & 0.0 & 0.0 & 0.0 & 0.0 & 0.0 & 0.0 & 0.0 & 0.0 & 0.0 & & \\
\hline 0.0 & 0.0 & 0.0 & 0.0 & 0.0 & 0.0 & 0.0 & 0.0 & 0.0 & 0.0 & ROW & 53 \\
\hline 0.0 & 0.0 & -140.9 & -49.7 & 341.7 & 936.2 & 1468.3 & 1810.6 & 1999.4 & 2132.9 & & \\
\hline 2263.4 & 2399.8 & 2672.8 & 2879.1 & 3036.5 & 3171.4 & 3351.7 & 3535.3 & 3226.0 & 2893.4 & & \\
\hline 2619.2 & 2372.0 & 2137.8 & 1902.8 & 1674.9 & 1619.3 & 1545.6 & 1494.3 & 0.0 & 0.0 & & \\
\hline 0.0 & 0.0 & 0.0 & 0.0 & 0.0 & 0.0 & 0.0 & 0.0 & 0.0 & 0.0 & & \\
\hline 0.0 & 0.0 & 0.0 & 0.0 & 0.0 & 0.0 & 0.0 & 0.0 & 0.0 & 0.0 & & \\
\hline 0.0 & 0.0 & 0.0 & 0.0 & 0.0 & 0.0 & 0.0 & 0.0 & 0.0 & 0.0 & ROW & 54 \\
\hline 0.0 & 0.0 & 0.0 & -130.4 & 104.1 & 435.9 & 960.0 & 1353.9 & 1628.3 & 1819.2 & & \\
\hline 1971.5 & 2116.8 & 2338.9 & 2565.9 & 2770.5 & 2899.1 & 3015.3 & 3105.9 & 3235.9 & 2933.6 & & \\
\hline 2649.1 & 2388.0 & 2160.0 & 1989.9 & 1595.6 & 1543.6 & 1507.3 & 1463.6 & 0.0 & 0.0 & & \\
\hline 0.0 & 0.0 & 0.0 & 0.0 & 0.0 & 0.0 & 0.0 & 0.0 & 0.0 & 0.0 & & \\
\hline 0.0 & 0.0 & 0.0 & 0.0 & 0.0 & 0.0 & 0.0 & 0.0 & 0.0 & 0.0 & & \\
\hline
\end{tabular}


APPENDIX 2. STARTING HEADS USED FOR SIMULATION-Continued

\begin{tabular}{|c|c|c|c|c|c|c|c|c|c|c|}
\hline 0.0 & 0.0 & 0.0 & 0.0 & 0.0 & 0.0 & 0.0 & 0.0 & 0.0 & 0.0 & ROW \\
\hline 0.0 & 0.0 & 0.0 & 0.0 & -38.8 & 292.6 & 750.4 & 1145.0 & 1395.6 & 1613.6 & \\
\hline 1804.8 & 2005.9 & 2134.1 & 2326.9 & 2571.2 & 2777.0 & 2915.6 & 3006.3 & 3148.0 & 3216.5 & \\
\hline 2834.6 & 2488.0 & 2224.4 & 2001.3 & 1766.6 & 1620.1 & 1558.9 & 1504.6 & 0.0 & 0.0 & \\
\hline 0.0 & 0.0 & 0.0 & 0.0 & 0.0 & 0.0 & 0.0 & 0.0 & 0.0 & 0.0 & \\
\hline 0.0 & 0.0 & 0.0 & 0.0 & 0.0 & 0.0 & 0.0 & 0.0 & 0.0 & 0.0 & \\
\hline 0.0 & 0.0 & 0.0 & 0.0 & 0.0 & 0.0 & 0.0 & 0.0 & 0.0 & 0.0 & ROW \\
\hline 0.0 & 0.0 & 0.0 & 0.0 & 0.0 & 62.9 & 255.7 & 638.8 & 1005.3 & 1314.6 & \\
\hline 1575.7 & 1848.1 & 1967.5 & 2159.4 & 2312.1 & 2530.1 & 2716.4 & 2824.0 & 2894.4 & 2940.2 & \\
\hline 2859.2 & 2597.6 & 2451.8 & 2241.6 & 1860.9 & 1699.0 & 1637.7 & 1583.1 & 0.0 & 0.0 & \\
\hline 0.0 & 0.0 & 0.0 & 0.0 & 0.0 & 0.0 & 0.0 & 0.0 & 0.0 & 0.0 & \\
\hline 0.0 & 0.3 & 0.0 & 0.0 & 0.0 & 0.0 & 0.0 & 0.0 & 0.0 & 0.0 & \\
\hline 0.0 & 0.0 & 0.0 & 0.0 & 0.0 & 0.0 & 0.0 & 0.0 & 0.0 & 0.0 & ROW \\
\hline 0.0 & 0.0 & 0.0 & 0.0 & 0.0 & 36.8 & 104.0 & 336.7 & 659.7 & 1035.4 & \\
\hline 1399.1 & 1669.9 & 1727.1 & 1876.4 & 2181.4 & 2421.1 & 2579.8 & 2645.0 & 2640.6 & 2672.0 & \\
\hline 2648.3 & 2591.2 & 2526.1 & 2410.8 & 2036.3 & 1791.3 & 1751.8 & 0.0 & 0.0 & 0.0 & \\
\hline 0.0 & 0.0 & 0.0 & 0.0 & 0.0 & 0.0 & 0.0 & 0.0 & 0.0 & 0.0 & \\
\hline 0.0 & 0.0 & 0.0 & 0.0 & 0.0 & 0.0 & 0.0 & 0.0 & 0.0 & 0.0 & \\
\hline 0.0 & 0.0 & 0.0 & 0.0 & 0.0 & 0.0 & 0.0 & 0.0 & 0.0 & 0.0 & ROW \\
\hline 0.0 & 0.0 & 0.0 & 0.0 & 0.0 & 0.0 & 55.4 & 128.5 & 343.7 & 669.4 & \\
\hline 1021.9 & 1319.8 & 1435.2 & 1762.9 & 2235.4 & 2564.2 & 2736.4 & 2735.3 & 2631.9 & 2620.4 & \\
\hline 2615.0 & 2601.6 & 2546.3 & 2410.7 & 2154.8 & 1960.7 & 1889.2 & 0.0 & 0.0 & 0.0 & \\
\hline 0.0 & 0.0 & 0.0 & 0.0 & 0.0 & 0.0 & 0.0 & 0.0 & 0.0 & 0.0 & \\
\hline 0.0 & 0.0 & 0.0 & 0.0 & 0.0 & 0.0 & 0.0 & 0.0 & 0.0 & 0.0 & \\
\hline 0.0 & 0.0 & 0.0 & 0.0 & 0.0 & 0.0 & 0.0 & 0.0 & 0.0 & 0.0 & ROW \\
\hline 0.0 & 0.0 & 0.0 & 0.0 & 0.0 & 0.0 & 0.0 & 0.0 & 482.5 & 528.1 & \\
\hline 636.1 & 800.9 & 1028.7 & 1418.5 & 1841.5 & 2200.4 & 2462.4 & 2626.5 & 2700.5 & 2716.8 & \\
\hline 2704.4 & 2688.7 & 2670.6 & 2630.8 & 0.0 & 0.0 & 0.0 & 0.0 & 0.0 & 0.0 & \\
\hline 0.0 & 0.0 & 0.0 & 0.0 & 0.0 & 0.0 & 0.0 & 0.0 & 0.0 & 0.0 & \\
\hline 0.0 & 0.0 & 0.0 & 0.0 & 0.0 & 0.0 & 0.0 & 0.0 & 0.0 & 0.0 & \\
\hline 0.0 & 0.0 & 0.0 & 0.0 & 0.0 & 0.0 & 0.0 & 0.0 & 0.0 & 0.0 & ROW \\
\hline 0.0 & 0.0 & 0.0 & 0.0 & 0.0 & 0.0 & 0.0 & 0.0 & 654.0 & 683.6 & \\
\hline 745.0 & 837.9 & 968.8 & 1191.0 & 1583.8 & 2001.1 & 2345.7 & 2631.8 & 2788.6 & 2854.2 & \\
\hline 2830.9 & 2774.2 & 2739.5 & 2709.7 & 0.0 & 0.0 & 0.0 & 0.0 & 0.0 & 0.0 & \\
\hline 0.0 & 0.0 & 0.0 & 0.0 & 0.0 & 0.0 & 0.0 & 0.0 & 0.0 & 0.0 & \\
\hline 0.0 & 0.0 & 0.0 & 0.0 & 0.0 & 0.0 & 0.0 & 0.0 & 0.0 & 0.0 & \\
\hline 0.0 & 0.0 & 0.0 & 0.0 & 0.0 & 0.0 & 0.0 & 0.0 & 0.0 & 0.0 & ROW \\
\hline 0.0 & 0.0 & 0.0 & 0.0 & 0.0 & 0.0 & 0.0 & 0.0 & 0.0 & 0.0 & \\
\hline 0.0 & 0.0 & 0.0 & 0.0 & 0.0 & 0.0 & 0.0 & 2806.3 & 2859.9 & 2909.6 & \\
\hline 2980.2 & 2868.3 & 2824.6 & 0.0 & 0.0 & 0.0 & 0.0 & 0.0 & 0.0 & 0.0 & \\
\hline 0.0 & 0.0 & 0.0 & 0.0 & 0.0 & 0.0 & 0.0 & 0.0 & 0.0 & 0.0 & \\
\hline 0.0 & 0.0 & 0.0 & 0.0 & 0.0 & $0.0^{\circ}$ & 0.0 & 0.0 & 0.0 & 0.0 & \\
\hline
\end{tabular}




\section{APPENDIX 3. PUMPAGE DATA USED IN SIMULATION}

(Pumpage units are cubic feet per second)

$\begin{array}{cc}\text { FIRST STRESS } & \text { PERIOD } \\ \text { LAYER } & \text { ROW } \\ 2 & 47 \\ 1 & 47 \\ 1 & 47 \\ 2 & 48 \\ 2 & 41 \\ 2 & 42 \\ 1 & 42 \\ 2 & 45 \\ 2 & 46 \\ 1 & 47 \\ 2 & 47 \\ 2 & 47 \\ 1 & 47 \\ 1 & 48 \\ 2 & 48 \\ 2 & 49 \\ 2 & 49 \\ 2 & 50 \\ 1 & 50 \\ 1 & 51 \\ 2 & 49 \\ 2 & 50 \\ 2 & 50 \\ 2 & 50 \\ 2 & 50 \\ 2 & 49 \\ 2 & 48 \\ 4 & 100\end{array}$

SECOND STRESS PERIOD

$$
\begin{array}{cc}
\text { COLUMN } & \text { RATE } \\
29 & -1.7265 \\
29 & -1.72650 \\
29 & -1.72650 \\
30 & -1.7265 \\
25 & -0.6906 \\
27 & -0.6906 \\
27 & -0.69060 \\
30 & -0.6906 \\
31 & -0.6880 \\
31 & -0.68800 \\
35 & -1.7260 \\
35 & -1.7260 \\
34 & -1.72600 \\
34 & -1.72600 \\
30 & -0.7670 \\
29 & -0.7670 \\
28 & -0.7670 \\
27 & -0.7670 \\
28 & -0.7670 \\
28 & -0.7670 \\
30 & -0.7670 \\
30 & -0.7670 \\
30 & -0.7670 \\
35 & -2.7620 \\
34 & -2.7620 \\
38 & -1.726 \\
35 & -1.726 \\
&
\end{array}
$$

COLUMN RATE$$
\begin{array}{ll}
29 & -1.7265 \\
29 & -1.7265
\end{array}
$$$$
29-1.7265
$$$$
30
$$$$
25
$$$$
27
$$$$
\begin{aligned}
& 27 \\
& 30
\end{aligned}
$$$$
31
$$$$
\begin{aligned}
& 31 \\
& 28
\end{aligned}
$$$$
28
$$$$
\begin{aligned}
& 28 \\
& 27
\end{aligned}
$$$$
31
$$$$
\begin{aligned}
& 31 \\
& 34
\end{aligned}
$$$$
33
$$$$
\begin{aligned}
& 32 \\
& 34
\end{aligned}
$$$$
\begin{aligned}
& 34 \\
& 37
\end{aligned}
$$$$
\begin{aligned}
& 37 \\
& 36
\end{aligned}
$$$$
\begin{aligned}
& 36 \\
& 38
\end{aligned}
$$$$
\begin{aligned}
& 38 \\
& 37
\end{aligned}
$$$$
\begin{aligned}
& 31 \\
& 30
\end{aligned}
$$$$
30
$$$$
30
$$$$
-1.7265
$$$$
-0.6906
$$$$
-0.69060
$$$$
-0.6906
$$$$
-0.6906
$$$$
-0.69060
$$$$
-2.0720
$$$$
-2.07200
$$$$
-2.07200
$$$$
-2.0720
$$$$
-1.3810
$$$$
-1.38100
$$$$
-1.7260
$$$$
-1.72600
$$$$
-2.07200
$$$$
-2.0720
$$$$
-1.3810
$$$$
-1.38100
$$$$
-1.3810
$$$$
-1.38100
$$$$
-0.98600
$$$$
-0.9860
$$$$
-0.98600
$$$$
-0.9860
$$

$\begin{array}{ll}\text { PERMIT NO. } & \text { BASIN } \\ 54061 & 168 \\ 54060 & 168 \\ 54068 & 168 \\ 54069 & 168 \\ 53949 & 169 A \\ 53948 & 169 A \\ 53947 & 169 A \\ 53952 & 169 \mathrm{~B} \\ 53951 & 169 \mathrm{~B} \\ 53950 & 169 \mathrm{~B} \\ 54058 & 210 \\ 54059 & 210 \\ 54056 & 210 \\ 54057 & 210 \\ 54066 & 211 \\ 54065 & 211 \\ 54106 & 211 \\ 54064 & 211 \\ 54063 & 211 \\ 54062 & 211 \\ 54072 & 211 \\ 54070 & 211 \\ 54071 & 211 \\ 54073 & 216 \\ 54074 & 217 \\ 54075 & 218 \\ 54076 & 218\end{array}$

$\begin{array}{ll}\text { PERMIT NO. BASIN } \\ 54061 & 168 \\ 54060 & 168 \\ 54068 & 168 \\ 54069 & 168 \\ 53949 & 169 \mathrm{~A} \\ 53948 & 169 \mathrm{~A} \\ 53947 & 169 \mathrm{~A} \\ 53952 & 169 \mathrm{~B} \\ 53951 & 169 \mathrm{~B} \\ 53950 & 169 \mathrm{~B} \\ 53958 & 171 \\ 53956 & 171 \\ 53957 & 171 \mathrm{~A} \\ 53959 & 171 \\ 53988 & 180 \\ 53987 & 180 \\ 53990 & 181 \mathrm{~A} \\ 53989 & 181 \\ 53991 & 182 \\ 53992 & 182 \\ 54033 & 202 \\ 54031 & 202 \\ 54034 & 202 \\ 54032 & 202 \\ 54043 & 208 \\ 54048 & 208 \\ 54044 & 208 \\ 54045 & 208 \\ & \end{array}$


APPENDIX 3. PUMPAGE DATA USED IN SIMULATION-Continued

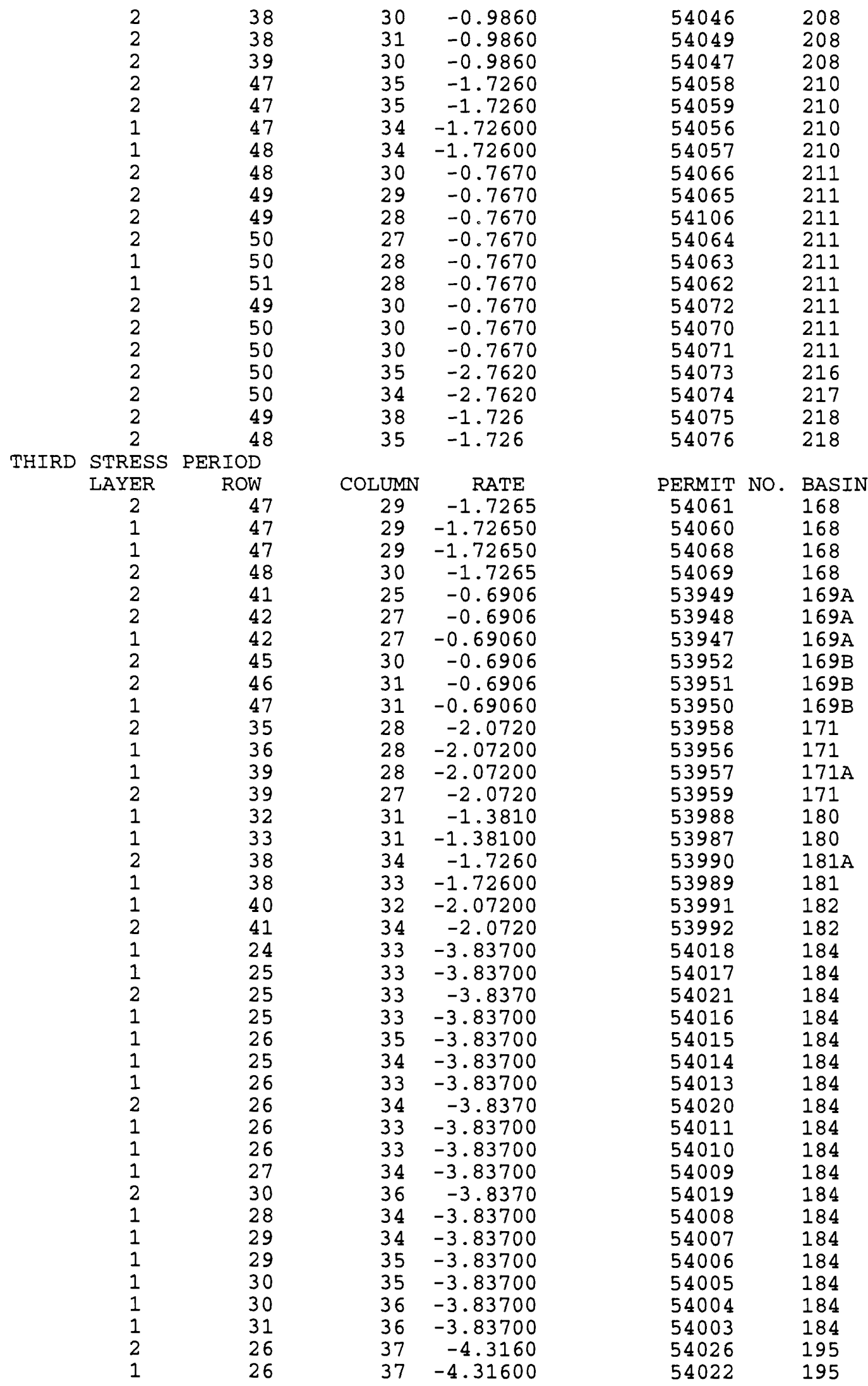




\section{APPENDIX 3. PUMPAGE DATA USED IN SIMULATION-Continued}

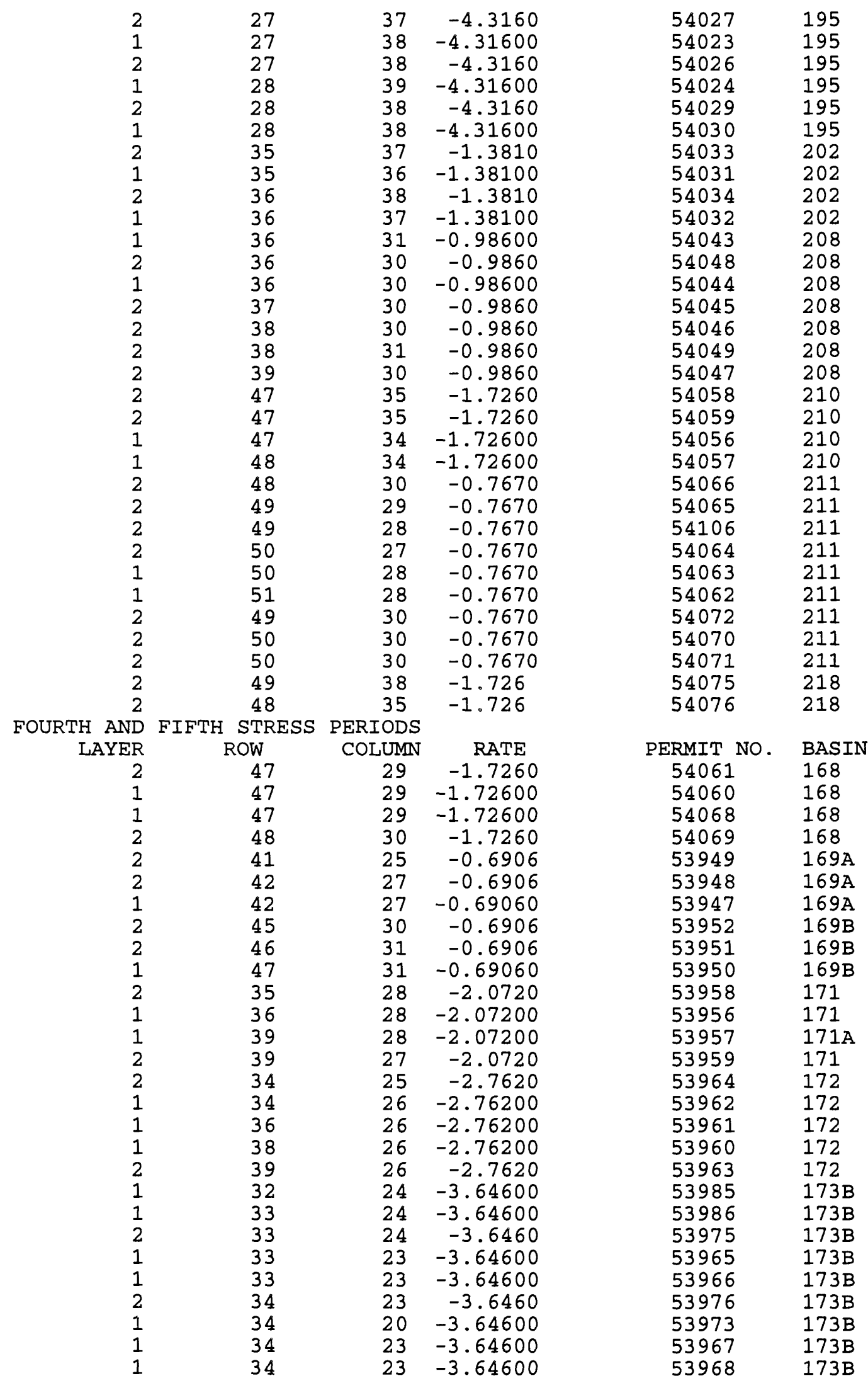


APPENDIX 3. PUMPAGE DATA USED IN SIMULATION-Continued

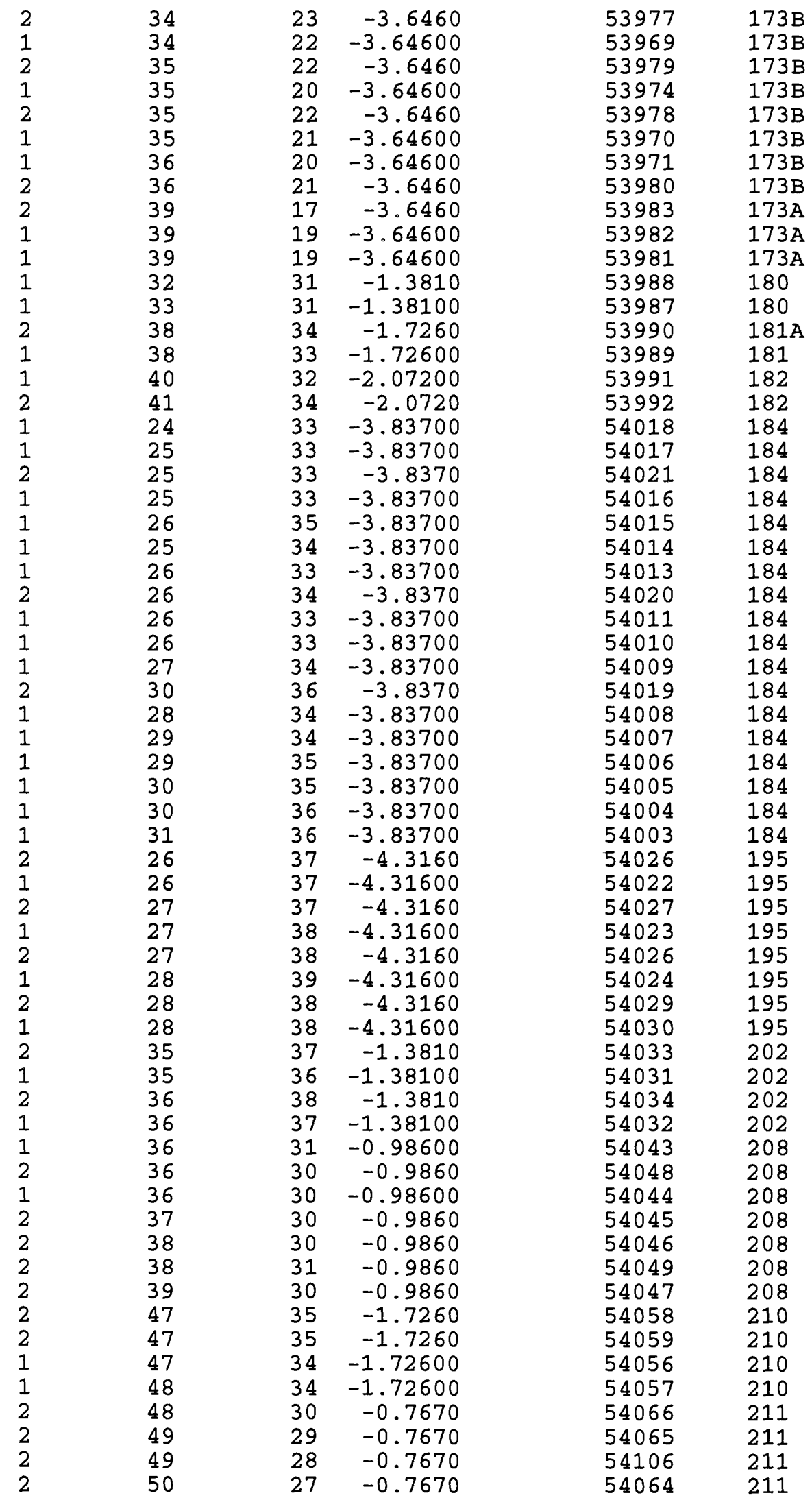


APPENDIX 3. PUMPAGE DATA USED IN SIMULATION-Continued

$\begin{array}{llllll}1 & 50 & 28 & -0.7670 & 54063 & 211 \\ 1 & 51 & 28 & -0.7670 & 54062 & 211 \\ 2 & 49 & 30 & -0.7670 & 54072 & 211 \\ 2 & 50 & 30 & -0.7670 & 54070 & 211 \\ 2 & 50 & 30 & -0.7670 & 54071 & 211 \\ 2 & 49 & 38 & -1.726 & 54075 & 218 \\ 2 & 48 & 35 & -1.726 & 54076 & 218\end{array}$

